\title{
Intelligent design? \\ Transforming intelligence in Georgia and Serbia
}

by

\section{Hans Francis Felber-Charbonneau}

\begin{abstract}
A thesis submitted to the Faculty of Graduate and Postdoctoral Affairs in partial fulfillment of the requirements for the degree of
\end{abstract}

Master of Arts

in

European, Russian and Eurasian Studies

Carleton University

Ottawa, Ontario

(C) 2012

Hans Francis Felber-Charbonneau 
Library and Archives

Canada

Published Heritage

Branch

395 Wellington Street

Ottawa ON K1A ON4

Canada
Bibliothèque et

Archives Canada

Direction du

Patrimoine de l'édition

395 , rue Wellington

Ottawa ON K1A ON4

Canada
Your file Votre référence

ISBN: 978-0-494-87781-4

Our file Notre référence

ISBN: $978-0-494-87781-4$

\section{NOTICE:}

The author has granted a nonexclusive license allowing Library and Archives Canada to reproduce, publish, archive, preserve, conserve, communicate to the public by telecommunication or on the Internet, loan, distrbute and sell theses worldwide, for commercial or noncommercial purposes, in microform, paper, electronic and/or any other formats.

The author retains copyright ownership and moral rights in this thesis. Neither the thesis nor substantial extracts from it may be printed or otherwise reproduced without the author's permission.
AVIS:

L'auteur a accordé une licence non exclusive permettant à la Bibliothèque et Archives Canada de reproduire, publier, archiver, sauvegarder, conserver, transmettre au public par télécommunication ou par l'Internet, prêter, distribuer et vendre des thèses partout dans le monde, à des fins commerciales ou autres, sur support microforme, papier, électronique et/ou autres formats.

L'auteur conserve la propriété du droit d'auteur et des droits moraux qui protege cette thèse. $\mathrm{Ni}$ la thèse ni des extraits substantiels de celle-ci ne doivent être imprimés ou autrement reproduits sans son autorisation.
In compliance with the Canadian Privacy Act some supporting forms may have been removed from this thesis.

While these forms may be included in the document page count, their removal does not represent any loss of content from the thesis.
Conformément à la loi canadienne sur la protection de la vie privée, quelques formulaires secondaires ont été enlevés de cette thèse.

Bien que ces formulaires aient inclus dans la pagination, il n'y aura aucun contenu manquant. 


\begin{abstract}
The 1990s saw the emergence of authoritarian governments and the outbreak of civil war in the Caucasus and the Balkans. After a decade of turbulence, the peoples of Georgia and Serbia overthrew corrupt regimes. In both countries, transforming the security and intelligence services that had been pillars of the previous regimes was a priority for the new governments.

This thesis will examine the reform of the security and intelligence services in Georgia and Serbia. It will test the hypothesis that the main challenges to successful reform are a lack of determination on the part of the political elite and institutional continuity with pre-revolutionary services.

This thesis examines intelligence reform at the historical, political and organizational levels, examining the historical legacies of the security and intelligence services' predecessors, the relations between the political class and the services and their internal workings and control mechanisms.
\end{abstract}




\section{Acknowledgements}

This thesis is the culmination of ideas and support from a great deal of people. First and foremost. I would like to thank my thesis advisor Mark Biondich for his meticulous work and support. In addition, I would like to thank Peter Konecny for his help and contacts.

I would also like to thank those that graciously accepted to meet me in Belgrade and Tbilisi during the fall and winter of 2010-2011. Their insight and explanation of the situation helped ground my research firmly in the real impacts of the subject of this study.

Additionally, I thank Allison and Jean for graciously accepting to review draft after draft of chapter after chapter of this thesis. Finally, I would like to acknowledge the continued influence and support of my grandfather Hans through years of studies. 


\section{Table of Contents}

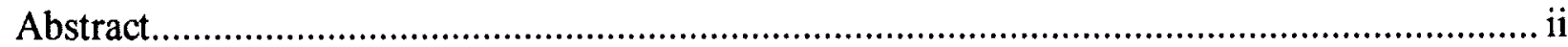

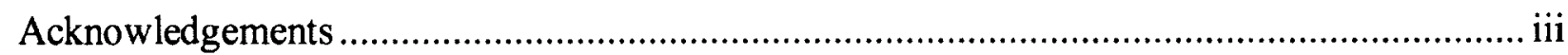

Chapter I: Introduction and theoretical framework .............................................................. 1

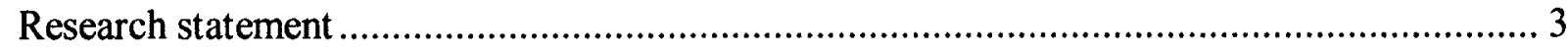

Comparative analysis of Serbia and Georgia .................................................................... 4

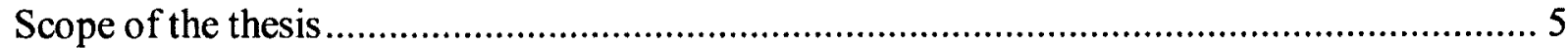

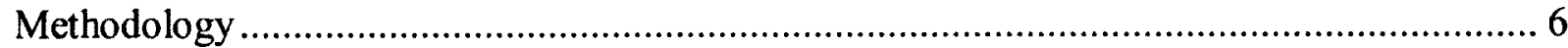

Assumptions: the role of the state and democratization ...................................................... 9

Framework for analysis: Security sector and intelligence reform ........................................ 11

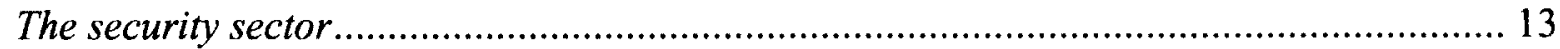

Objectives of security sector reform ....................................................................... 14

Contexts for security sector reform ........................................................................... 15

A technical and normative process.............................................................................. 16

Intelligence, security intelligence and intelligence reform................................................ 19

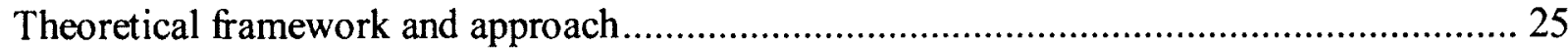

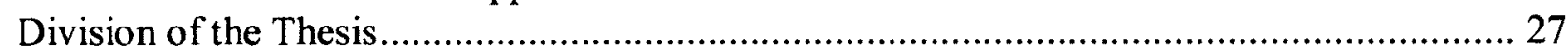

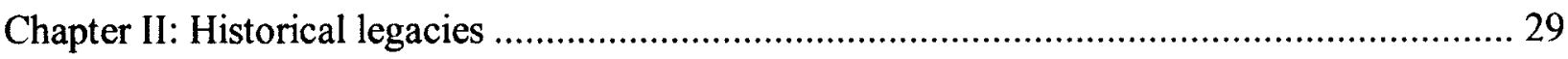

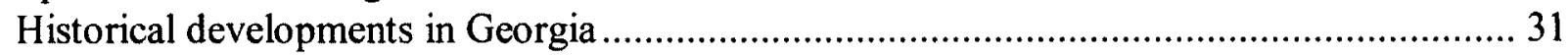

The shadows of history: Historical developments in Serbia.................................................. 48

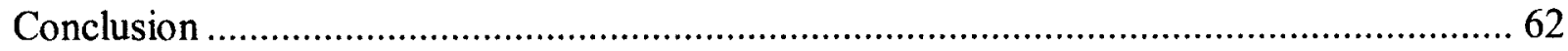

Chapter III

Strange Bedfellows: Democratic institutions and intelligence services......................................6 64

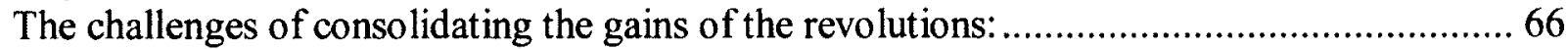

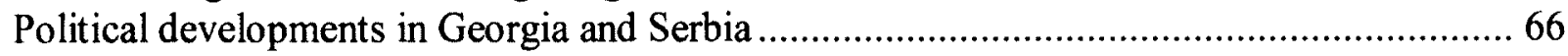

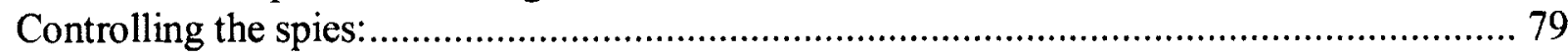

The establishment of executive control over the security and intelligence services................ 79

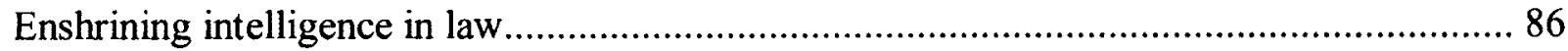

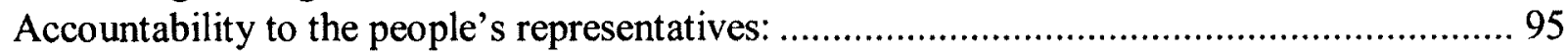

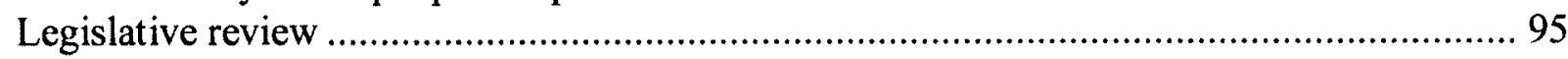

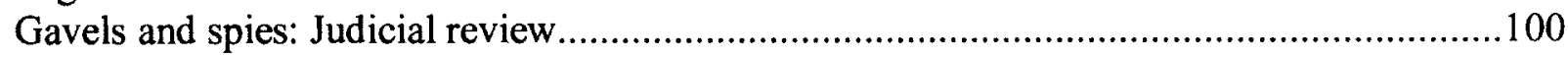

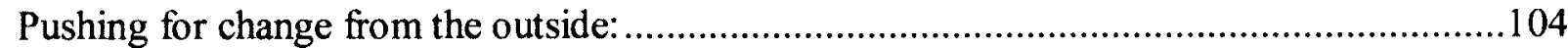

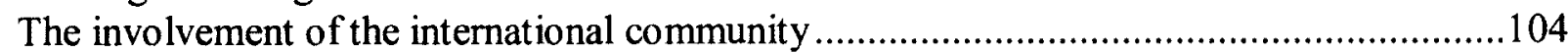

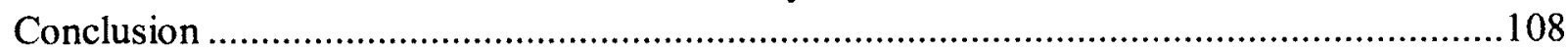

Chapter IV

Through the looking glass: Examining the inner workings of the intelligence community ........112

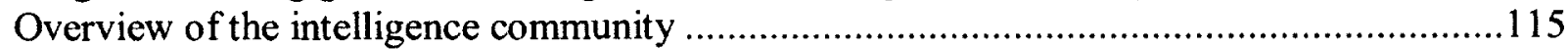

A failure to face the past: Lustration attempts in Georgia and Serbia ..................................126

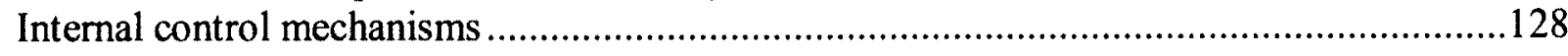

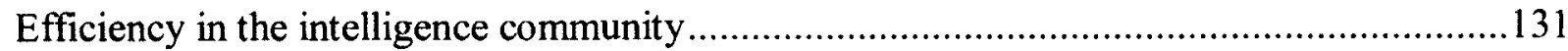

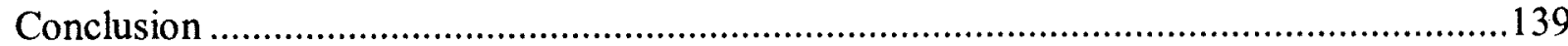

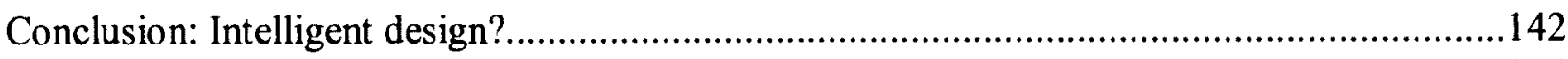

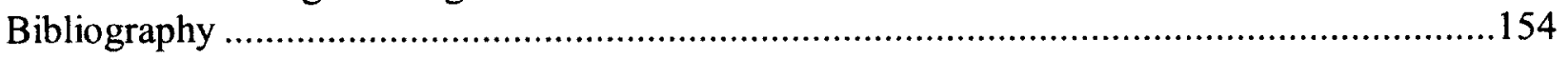




\section{Chapter I Introduction and theoretical framework}

The state has become the central actor in modern societies. Its main task is to preserve security through its monopoly on the legitimate use of violence. By tradition, this has been done through the military and the police. However, an additional type of institution, which has customarily been associated with police work, has evolved over the centuries becoming a central presence in the modern state: the security and intelligence services. In both Yugoslavia and the Soviet Union, one of the cornerstones of the communist regimes was the reliance on politically loyal security services that would protect the government and hunt down political opponents of the regime. Both of these countries brutally repressed opposition at home and would sometimes go so far as eliminating outspoken opponents abroad.

In Central and Eastern Europe, the security services of the communist era were disbanded after 1989 and in many cases former officers were barred from political office and government service. However, in both Serbia and Georgia, the 1990s were a decade of uncertainty and civil war. The wars of Yugoslav succession had a lasting impact on the Serbian services, while the declaration of independence in Georgia left the republic with the task of creating new security services. During this period, the security and intelligence services of the two countries became pillars of regimes that were increasingly authoritarian, although the exactions of Eduard Shevardnadze's government were not comparable to those of Slobodan Milošević's regime. 
In October 2000 and November 2003 respectively, the peoples of Serbia and Georgia respectively firmly rejected over a decade of authoritarianism. While the new governments in Belgrade and Tbilisi began democratizing public institutions, attempts at reforming the security and intelligence services remained nebulous. This situation can be compared with the end of communist regimes throughout Central and Eastern Europe in the late 1980s and the early 1990s, when it became crucial for new democratic governments to reform security and intelligence agencies. Indeed, security and intelligence services have traditionally played a central role as guardians of authoritarian regimes and their transformation is fundamental to the consolidation of democratic gains. Their participation in enforcing the new laws and reforms of transitioning states is vital for the success of the transformation process. Undeniably, proper reform is not possible when the former instruments of repression and surveillance have not been transformed from political security services with the preservation of the regime as their main mission to security intelligence services with apolitical mandates, proper democratic oversight and a culture of respect for the rule of law. In the case of Serbia and Georgia, the end of the Cold War and communism did not signify the end of authoritarianism nor of the role of the security and intelligence services as guardians of undemocratic governments. These two states went through a particularly difficult transformation, characterized by authoritarian governments, civil war and the criminalization of large portions of state institutions.

Outside the English-speaking world, intelligence studies have been relatively sparse, although there has been growing academic attention given to intelligence studies throughout Europe, with an increasing amount of literature being provided from the 
experience of Central and Eastern European states. The objective of this thesis is to add to the existing literature by examining intelligence reform in two post-communist, postauthoritarian and post-conflict states which had embraced liberal-democratic values and to draw the appropriate lessons from their experiences. In addition, the proposed thesis will examine the suitability of the intelligence reform model in transitioning states, thus potentially challenging the consensus present in the literature on the main means and methods to achieve the desired goal.

The approach that will be taken, as shall be discussed in a subsequent section, is based on a number of theoretical frameworks that have been developed in the fields of security sector reform, civil-military relations and intelligence reform. It will systematically examine a number of reform elements divided into three main levels of analysis, namely the political, organizational and international levels. In addition, the present thesis will closely examine the historical development of the security and intelligence services in these two states.

\section{Research statement}

This thesis is based on the assumption that the reform efforts in post-revolution Georgia and Serbia have been challenging, especially with regards to the security and intelligence services. It will address three main themes, beginning with the question: Why was the intelligence reform process so challenging in these two states? The working hypothesis put forward is that intelligence reform was impaired by the lack of strong political will to transform the security services after the change in government. An additional hypothesis that will be examined is that an explanation can be found in the 
historical legacies of the security and intelligence services of these two states and that institutional continuity after the revolution limited the internal appetites for reforms.

To answer these questions properly, this thesis will examine the criteria, as elaborated in the literature, which are deemed necessary for adequate reform of a state's security and intelligence services. The two main elements that will be examined are the levels of democratic control over the security and intelligence services and the mechanisms that have been established to increase the efficiency of the services. This leads to the question: Can the theoretical framework guiding intelligence reform be applied to all states? The working hypothesis is that the success of the model is dependent on the decision by political elites to embrace and pursue a liberal-democratic system of government. If this is not the case, then the model cannot be applied as it is firmly rooted in liberal-democratic values.

\section{Comparative analysis of Serbia and Georgia}

At first glance, Serbia and Georgia may strike the observer as an odd choice for a comparison. However, a number of elements make these two states worthy of comparison, both historically and politically. Having both spent a majority of the twentieth century as components of larger communist federations, Serbia and Georgia achieved de facto independence during the early 1990s. While Serbia remained formally within the Federal Republic of Yugoslavia (FRY) and the subsequent State Union of Serbia and Montenegro until 2006, this was only de jure. In both of these states, the 1990s were a decade of political instability and civil conflict with governments marred by conflict and under the control of corrupt and authoritarian leaderships. As a result, state institutions, including the security and intelligence services, and large sections of the 
economy stagnated as a result of nepotism and the predominance of organized crime and of the black market with the national security and intelligence apparatus being used as tools of the regime, aimed principally at quelling internal dissension.

Both Serbia and Georgia went through peaceful revolutions which saw a change in government and the removal of authoritarian figures, as well as developments towards the establishment of democratic institutions. Both now aim for membership in the European Union. In doing so, Serbia and Georgia have rejected their authoritarian pasts, as they both share a post-communist and post-conflict experience following the end of the Cold War and the disintegration of the Soviet Union.

Finally, Serbia and Georgia both had to deal with secessionist areas; Kosovo in the Serbian case and Abkhazia, South Ossetia and Adjara in Georgia. In both cases, other international actors, namely the U.S. and NATO in Kosovo and Russia in South Ossetia and Abkhazia, de facto imposed the final status of these regions. Although the magnitudes of the conflicts were different, both states unsuccessfully attempted to regain control over their secessionist regions by force, which had an impact on their respective security services.

The common experience of having rejected authoritarian governments and of turning firmly towards Europe and liberal-democracy, as well as a history of conflict and corruption of the state, makes Serbia and Georgia unique states in Europe. Lessons can be drawn from their respective experiences.

\section{Scope of the thesis}

This thesis will examine the developments of the security and intelligence services in Serbia and Georgia and their historical antecedents. While the emphasis will 
be on developments following the popular revolutions of the early 2000s, a detailed look at the historical development of the services will be provided. This examination will provide an understanding for some of the underlying challenges to the reform of the contemporary security and intelligence services in Georgia and Serbia. The thesis will limit itself to the security and intelligence sectors and will not include the police, armed forces or border guards, although the role of military intelligence will be examined as required, as will be paramilitary formations that were formed and used as supporters of the state during the conflicts in both states.

\section{Methodology}

There is a fundamental challenge in researching institutions that have secrecy at their core. However, there is an abundance of sources, both primary and secondary, dealing with the post-communist and post-conflict transformations in Serbia and Georgia as well as the role of the security and intelligence services in these transitional societies.

Various sources were examined to compile the information provided in the present thesis. The main primary sources are provided by official government publications, such as laws, decrees and reports. While these sources do not always reflect the reality of the ground, they clearly indicate what the objectives and standards are. Official documents, be they decrees, laws, policy, state or administrative documents are crucial resources for those seeking to sort out the organization of security and intelligence services. Although there are challenges with such documents, such as determining their implementation, they are key in determining the direction policy makers wish to give security and intelligence services. 
International organizations also play a crucial role in assessing security sector reform, especially the European Union and the North Atlantic Treaty Organization. These organizations have a number of agreements with Serbia and Georgia, governing security sector reform. The legacy of the 1990s is an important factor in analysing the current state of the security and intelligence services. In terms of primary sources, the International Criminal Tribunal for the former Yugoslavia (ICTY) is an indispensable source of materials related to the operation of the Serbian security and intelligence services during the 1990's. The documents put forward by the Tribunal, including expert reports on the financing mechanisms and the chain of command of the Ministry of the Interior and State Security during that period will shed important light on these services. Is should be noted that the ICTY is viewed as biased by many Serbs. In addition, the President of the ICTY presents bi-annual progress reports to the United Nations Security Council (UNSC), which includes an assessment of the cooperation of the former Yugoslav states with the Tribunal. The reporting mechanisms of the ICTY on the level of cooperation between the Serbian government, including the security and intelligence services, provides an important indicator in the transformation of the security and intelligence services in Serbia, as understood by international actors such as the UN, the EU and NATO.

News media are often the main sources of information but need to be approached with caution, as these may be either too negative simply echo the official government position on the security services. Media sources will assist in keeping up to date on developments in both states. The Balkan Investigative Reporting Network (BIRN) and its newspaper 'Balkan Insight' provide a network of local investigative journalists. A similar 
network, the Institute for War and Peace Reporting (IWPR), provides weekly updates on the workings of the International Criminal Tribunal for the former Yugoslavia and has a network of reporters in the Southern Caucasus and in Georgia, in particular with the Caucasus Reporting Service. In addition to these local sources, media sources in English, French, Italian and German will be used. Because of the nature of security and intelligence services, information on them is more difficult to find and as such, the methodology for analysing these media sources will remain broad. These news sources, in addition to providing additional information, will also provide an indication on the involvement of civil society in monitoring the actions of the services.

A number of non-governmental organizations (NGOs) publish reports on these two states. The most useful reports are those from the International Crisis Group, as well as the Helsinki Committee for Human Rights in Serbia and Human Rights Watch reports for Georgia. Additionally, the thesis will draw on reports from other NGOs that monitor state institutions and the security sector of these states, although it must be noted that many of these are considered to have a pro-Western bias because of their promotion of liberal-democratic values.

One of the main challenges confronting this researcher was to find precise information on the transformation of the security and intelligence services in both states. Secondary sources on intelligence reform are readily available, although few studies, let alone a comparative analysis, have been made specifically on the intelligence services of these two states. This research theme will thus provide me with an innovative subject and format which will be based on the literature readily available to the public. 


\section{Assumptions: the role of the state and democratization}

The analysis in the present thesis will be based on a number of working assumptions. The first of these is that the modern state is at the centre of society and that it alone has the authority to control the security sector. The second assumption is that the countries that will be addressed in the present thesis, namely Georgia and Serbia, have taken steps to transform themselves into liberal-democratic states. These two elements are crucial to the analysis of the development of the security services in Serbia and Georgia because of the normative aspects of security sector reform.

The modern state has come to play a central role in modern societies. It can be stated that it is at the centre of analysis and exists as an independent entity, although it is of course rooted in the society that saw it developed. ${ }^{1}$ However, the state needs proper legitimacy for its existence. According to Max Weber, this legitimacy can come through a number of means, including tradition and charisma as well as through rational-legal construction. ${ }^{2}$ The construction of a rational-legal framework also leads to the creation of state institutions, or bureaucracy, to implement this legal framework. ${ }^{3}$ While there have been debates throughout history over the role of the state and government, it cannot be denied that at the heart of the state is its ability to monopolise the use of force over a distinct territory. ${ }^{4}$ Weber introduced this concept as the state monopoly on violence, also known as the state monopoly on the legitimate use of force. ${ }^{5}$ It is through this monopoly that the state secures its status at the centre of society.

\footnotetext{
' M. Gazibo \& J. Jenson, La politique comparée: Fondements, enjeux, et approches théoriques (Montréal, 2004), p.201

${ }^{2}$ M. Weber, "S.7 Legitime Ordnung" in Wirschaft und Gesseschaft. (Electronic version, 1922).

${ }^{3}$ Ibid

${ }^{4}$ Weber 1922, "S.17. Politischer Verband, Hierokratischer Verband", Wirtschaft und Gesellschaft.

${ }^{5}$ Weber, Politik als Beruf (Electronic Version, 1919).
} 
The monopoly on violence has historically been achieved through the establishment of institutions to carry out and enforce government policy. This reality has led to the present thesis taking an institutional approach to the development of the security sector. Classical institutionalism focuses on the study of democratic institutions and is based on the assumptions that the actors are rational and that institutions function within legislative and legal frameworks. ${ }^{6}$ The security sector is the tool through which the state enforces its monopoly on the legitimate use of force. ${ }^{7}$ Indeed, it has been argued that it is through the security sector that the state achieves its monopoly on violence. ${ }^{8}$ One of the main challenges to the state monopoly on the use of violence is the presence of nonstate security actors, such as paramilitary units, militias and private security companies. ${ }^{9}$ This assumption thus rests on the continued presence of the security sector within the framework of that state, as institutions that consolidate the state's monopoly on the legitimate use of force over a distinct sovereign territory. However, there have been increased criticisms of the state monopoly as authoritarian regimes have used the control of the security forces to repress segments of their own population. This issue adds the need to qualify the legitimacy of the state monopoly by the framework of the state itself, needing to be democratic.

Building upon the previous section, it must be noted that there are normative arguments about the type of state that can hold a monopoly on the legitimate use of force. The consensus that is to be found within the literature about intelligence reform is based within the normative framework of the liberal democratic state. In both Georgia and

\footnotetext{
${ }^{6}$ Gazibo \& Jenson, pp. 192-193

${ }^{7}$ T. Edmunds, Security Sector Reform in Transforming Societies (New York, 2007), p.1

${ }^{8}$ H. Hänggi, "Sicherheitssektorreform (SSR) - Konzept und Kontexte", Sicherheit + Frieden, Iss. 3, (2005) p. 120

Hänggi, p. 120
} 
Serbia, there was a peaceful revolution against the local authoritarian government. These revolutions led the countries into a democratization process. There are a number of phases of democratization in authoritarian regimes, as represented in Gazibo and Jenson. The first phase is liberalization, which occurs when the regime releases some of its grasp on society with limited reform efforts. ${ }^{10}$ This can be followed, as was the case in Georgia and Serbia, with the democratic transition itself from the collapse of the authoritarian regime to the introduction of a new government. This phase usually centres itself on the organization of democratic elections. ${ }^{11}$ The third phase consists of the consolidation period during which the new democratic government consolidates its control over governmental institutions, reforming said institutions and organizing free and democratic elections. ${ }^{12}$ The means through which the new government establishes and consolidates its control over the security and intelligence services are an important component of intelligence and security sector reform and will be discussed in depth in the present thesis.

\section{Framework for analysis: Security sector and intelligence reform}

\section{Security sector reform}

The end of the Cold War and the collapse of the Soviet Union (USSR) saw an increase in international activism by Western states into conflicts throughout Africa and the Eurasian continent. Along with an increase in international peace missions and international aid, the necessity of reforming corrupt and militarized security services was quickly made plainly clear. Security sector reform evolved as a concept during the $1990 \mathrm{~s}$

\footnotetext{
${ }^{10}$ Gazibo \& Jenson, p. 174

11 Ibid, p.175

12 Ibid, pp.176-177
} 
with specific regard to former communist countries and other states, especially in Africa, that had to reform their governing structures to avoid state failure.

Security sector reform gained prominence as the interdependence between security and development became increasingly obvious and played an important role in these two fields. ${ }^{13}$ The twin pillars of security sector reform must be, first and foremost, establishing effective democratic control of the security sector, and ensuring the efficiency of the security sector. The linkage between security and development, Edmunds argues, is based on three assumptions. Firstly, that basic security and safety is seen as a primary role for further development, which provides a bias towards the building of state institutions and the state's monopoly on the legitimate use of violence. Secondly, that under-development and weak states often lead to civil war; and, thirdly, that the potential transnational nature of civil wars causes an "internalization of development and security concerns." ${ }^{14}$ Thus, security sector reform was developed as a way of harmonizing development and security in transitional countries, centring on the idea that these two elements are mutually dependent.

Although it has grown to deal with a number of different political contexts, security sector reform originally focused on Central and East European states that were undergoing post-communist transitions. The leading role in its development was accomplished by the Organisation for Security and Cooperation in Europe (OSCE) and NATO in military affairs while the European Union focused on non-military institutions of the security sector. ${ }^{15}$ Indeed, security sector reform was prompted by Western states and international organizations and concentrated on reducing waste and increasing

\footnotetext{
${ }^{13}$ Hänggi, p. 119

${ }^{14}$ Edmunds, SSR Transforming Societies, pp.20-21

${ }^{15}$ Hänggi, p. 120
} 
efficiency. ${ }^{16}$ Locally, security sector reform was a means through which the new political elites could establish control over security services that had often played a central role in preserving the authoritarian communist regimes across the region.

\section{The security sector}

In order to clearly grasp which state institutions are targeted by security sector reform, a working definition must be established. There has been some debate over what constitutes the security sector, ranging from narrow to wider definitions. Edmunds defines the security sector as "those organizations that apply and manage coercive force for collective purposes. ${ }^{\prime 17}$ However, this definition can limit the security sector to agencies that have the capacity to use brute force, depending on one's interpretation of the term "coercive" force. On the other hand, others have used a wider definition for the security sector which includes the judiciary and penal systems. ${ }^{18}$ This definition is very broad and dilutes the core of the security sector into wider government institutions that are peripheral to national security. While intelligence services are not usually defined by the use of coercive force, it is an important internal factor, considering some elements are in the military and others have police power, which is especially true in authoritarian societies. ${ }^{19}$ Indeed, although they are not always an armed presence, the intelligence services are a central part of the security sector. ${ }^{20}$ As a working definition, the present thesis will define the security sector as all the state institutions that have a mandate to engage in security and intelligence operations against identified threats to the state. The

\footnotetext{
${ }^{16}$ Ibid, p. 123

${ }^{17}$ Edmunds, SSR Transforming Societies, p. 23

${ }^{18}$ Hänggi, p. 121

${ }^{19}$ Edmunds, SSR Transforming Societies, p. 24

${ }^{20}$ Hänggi, p. 120
} 
institutions that compose the security sector include the armed forces, the police and the intelligence services, which form the core of the modern state's security sector.

\section{Objectives of security sector reform}

As it was eloquently put forward by Hänggi, "The departure point for security sector reform is a dysfunctional security sector." ${ }^{, 21}$ A dysfunctional security sector is inefficient, does not provide security for citizens of the state and is often corrupt. ${ }^{22}$ Indeed, under authoritarian regimes, the security sector tends to be involved in the economic life of the country and engages in nepotism, corruption and repression. ${ }^{23}$ From this departure point, Edmunds defines security sector reform as "the process through which security sector actors adapt to the political and organizational demands of transformation. ${ }^{24}$ In this case, transformation is understood as transition towards the establishment and implementation of the structures of the liberal democratic state. Internally, security sector reform is necessary in changing security, political and economic circumstances and internationally it is viewed as a way to serve as a conflict prevention and peace-building strategy by donors. ${ }^{25}$

Overall, security sector reform "aims to create a secure environment that is conducive to development, poverty reduction, good governance and, in particular, the growth of democratic states and institutions based on the rule of law."26 Thus, security sector reform has two functions, firstly to create an efficient, transparent security sector

${ }^{21}$ Ibid, p.121.

${ }^{22}$ Ibid

23 Ibid, p. 124

${ }^{24}$ Edmunds, SSR Transforming Societies, p. 25

${ }^{25}$ Ibid, p.1

${ }^{26}$ GFN-SSR. A Beginner's Guide to Security Sector Reform (Birmingham, 2007), p. 4 
and secondly to anchor democratic principles and good governance practices. ${ }^{27}$ This is echoed by Edmunds, for whom the aims of security sector reform include the twin pillars of democratic civilian control and effectiveness, while taking note that these are normative elements. ${ }^{28}$ Indeed, these concepts highlight the dual nature of security sector reform as a simultaneously technical and normative concept, an issue that will be addressed in a subsequent section.

\section{Contexts for security sector reform}

There is a broad agreement in the literature about the context in which security sector reform ought to occur. These three situations can be summarized as developing, post-authoritarian and post-conflict societies. ${ }^{29}$ Often, two or even all three of these situations can be found within the same society. Georgia and Serbia are examples of countries that are simultaneously undergoing a post-conflict and post-authoritarian transition following decades of communist and authoritarian rule and civil war. In postconflict and post-authoritarian societies, there is no democratic legacy and state institutions are geared towards authoritarian governance. ${ }^{30}$ This makes the task even more difficult because in most cases, the security sector must be reformed and is not established entirely anew. As such, the legacy of repression continues to delegitimize the security sector in the eyes of the public and politicians. In the post-conflict context, state institutions have often engaged in one side of the conflict. ${ }^{31}$ Indeed these two situations

\footnotetext{
${ }^{27}$ Hänggi, p. 121

${ }^{28}$ T. Edmunds, "Security Sector Reform: Concepts and Implementation", in Towards Security Sector Reform in Post-Cold War Europe: A Framewsork for Assessment edited by W.N. Germann \& T. Edmunds, (Baden Baden, 2003), p.12

${ }^{29}$ Ibid, 123

${ }^{30}$ Edmunds SSR Concepts, p. 15

${ }^{31}$ Hänggi, p. 124
} 
are present in Serbia and Georgia where the security services were deeply involved in the conduct of the civil war and in supporting the local regimes.

\section{A technical and normative process}

As has been mentioned, the literature underlines the fact that the process of security sector reform is both normative and technical. ${ }^{32}$ Certainly, although it is very technical and neutral at the implementation level, security sector reform as it is currently designed has a normative undercurrent which promotes a better way of functioning within the framework of the liberal democratic state. It has been argued that, "The emphasis on democratic civilian control serves to prove that SSR is a value oriented concept which strongly promotes the values of liberal democracy." ${ }^{33}$ In addition, security sector reform is rarely internally generated; it comes from external pressures and is not a neutral technical tool because of its inherent normative elements. ${ }^{34}$ Edmunds introduces "two main axes of normative prescription against which security sector reform is commonly premised," namely good governance and effectiveness. ${ }^{35}$ Because of these normative prescriptions, "It is thus about how the security sector contributes to the security of the political community, in an effective and efficient manner, and in the framework of democratic civilian control" ${ }^{36}$ It is of the utmost importance to keep in mind these normative undercurrents to the seemingly technical elements of security sector reform as they may or may not be desired by local actors. Indeed, von Bredow and Germann underline the need to adapt norms and values to local realities because not all

\footnotetext{
${ }^{32}$ Ibid, p. 121

33 J. Radoman, "The Concept of Security Sector Reform" Western Balkans Security Observer, n.11, (October-December 2008), p.6

${ }^{34}$ W. von Bredow \& W.N. Germann "Assessing Success and Failure: practical needs and theoretical answers" in Germann \& Edmunds (eds), p. 171

${ }^{35}$ Edmunds SSR Transforming Societies, p. 26

${ }^{36}$ Ibid, p.27
} 
demanded norms can be applied locally. ${ }^{37}$ This is echoed by Edmunds' opinion that to be successful, security sector reform must be adapted to local means and realities. It cannot be imposed from outside and must be led by the local authorities with the political will to do so. ${ }^{38}$

\section{Measuring success}

Having explored the nature and the objectives of security sector reform, it is vital to have a clear method of measuring success. While some technical benchmarks are generally agreed upon, as will be discussed, there is much division over what constitutes successful security sector reform. Edmunds notes that "security sector reform is a process rather than an end-point". ${ }^{39}$ Indeed it is a long-term process and while some elements may be considered a success in the first few years, an effort that is not comprehensively completed may mean failure after a decade. ${ }^{40}$ It should also be emphasized that the success of security sector reform does not occur in a vacuum and is dependent on the success of general democratization efforts. ${ }^{41}$

There is an emerging consensus that there needs to be agreement on objectives and criteria for security sector benchmarks that are currently lacking. ${ }^{42}$ A number of approaches can be taken to benchmark successful security sector reforms, such as: the ideal "tick-box" approach; a comparison to collective or regional developments; or a focus on process and facilitation that emphasizes empirical developments. ${ }^{43}$ This author's list of basic elements of security sector reform mirrors those that are widely present in the

\footnotetext{
${ }^{37}$ von Bredow \& Germann, p. 166

${ }^{38}$ Edmunds, SSR Concepts, p. 23

${ }^{39}$ Ibid, p.15

40 von Bredow \& Germann, p.72

${ }^{41}$ Hänggi, p. 124; Edmund, SSR Concepts, p., 20

${ }^{42}$ von Bredow \& Germann, pp.170-171

${ }^{43}$ Edmund, SSR Concepts, p. 21
} 
literature and notes that while EU and OSCE criteria have the most impact, they are not necessarily applicable outside Europe ${ }^{44}$ The role of the international community and especially of organizations such as NATO and the EU, in the process of reform will be discussed in depth in a subsequent chapter of this thesis.

When examining the results of the reform process, Martinusz establishes different state categories to compare the progress of security sector reform dividing between Third World states where the priority is to establish a strong central state and post-communist Europe, where the priority is the democratisation of the state and of the security sector. ${ }^{45}$ In Central and Eastern European (CEE) states, a method of benchmarking success that has been put forward is the theory that successful transition is clearly benchmarked as successful Euro-Atlantic integration. ${ }^{46}$ Edmunds proposes to look at what was done in other CEE states to find some broad strategies. Using the notions of first and second generation security sector reform, Edmunds views the most important primary development as the creation of civilian control mechanisms and legislative review. ${ }^{47}$ Edmunds introduces the concept of second generation security sector reform, which includes, among other elements, additional training and professionalization, second career training for downsized personnel, human resources development and engagement of civil society ${ }^{48}$ Second generation security sector reform will form the basis of the examination of the efficiency of the security and intelligence services, along with other mechanisms.

\footnotetext{
${ }^{44} \mathrm{Z}$. Martinusz "Measuring Success in Security Sector Reform: A proposal to improve the toolbox and establish criteria", 175-184, in German \& Edmunds (eds), p.179

${ }^{45}$ Martinusz, p. 175

${ }^{46}$ Edmunds, SSR Transforming Societies, p.4

${ }^{47}$ Edmund, SSR Concepts, p. 21

${ }^{48}$ Ibid, p.22
} 
Security sector reform is a long term process that aims at transforming the security sector of states into effective and accountable agencies intent on defending citizens and not just supporting a regime. Understood in this way, the concept of SSR is a necessary component of the present thesis as the subject of intelligence reform, which will be dealt with in the next section, falls squarely within this field.

\section{Intelligence, security intelligence and intelligence reform}

In order to explore control and review structures for security intelligence services, proper understanding of the function and development of the services is needed. The present section will begin by defining the terms "intelligence" and "security intelligence" themselves. This will be followed first by an overview of the role and objectives of security intelligence, as understood in the literature, and secondly by a review of the main means of control and review of the security and intelligence services.

Often described as the second oldest job in the world, intelligence work has constantly been present alongside societies' centres of power. Security and intelligence services have played an increasingly important role in supporting states during the twentieth century. During this period, they evolved from informal cabinet noir organizations to fully-fledged institutions that, in the case of regimes that were more repressive, were used to ensure the subservience of populations of entire states through a host of methods ranging from surveillance and coercion to the violent repression of society. However, intelligence gathering is at the core of the business of intelligence services. Clark defines intelligence as being "about reducing uncertainty in conflict." 49 Wilson provides a more narrow definition of intelligence as the "production of unbiased

\footnotetext{
${ }^{49}$ R.M. Clark, Intelligence Analysis: A target-centric approach, (Washington D.C., 2004), p.13.
} 


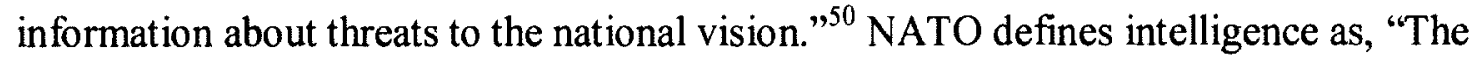
product resulting from the processing of information concerning foreign nations, hostile or potentially hostile forces or elements, or areas of actual or potential operations. The term is also applied to the activity which results in the product and to the organizations engaged in such activity." 51 In terms of the institutions that carry out intelligence work, Loch $\mathrm{K}$. Johnson views three main functions of intelligence services as the collection and analysis of information, covert action, and counter-intelligence. ${ }^{52}$ These definitions conceptualize what defines intelligence and intelligence services as state institutions that collect and analyze information from both public and non-public sources to support and inform government decision makers.

There are several types of intelligence, with the divisions most often being applied between foreign, domestic (or security) and military intelligence. In many countries, security intelligence is separated from foreign and military intelligence agencies, although in some cases foreign and domestic intelligence fall within the same organization, as is presently the case in Georgia. Of particular interest for the present thesis is domestic, also known as security, intelligence because of the role played by these institutions in the surveillance of citizens of the state. Security intelligence is specialized information relevant to internal security, public order and state security. ${ }^{53}$ This view tends to be reverberated in the literature, with Hannah, O'Brien and Rathmell stating that the mission of security intelligence services is to "obtain, correlate and evaluate intelligence relevant to internal security. Internal security aims to protect the

\footnotetext{
${ }^{50} \mathrm{P}$. Wilson, "The contribution of intelligence services to security sector reform" in Conflict, Security \& Development, Vol.5, Iss. I (April 2005), p.92

${ }^{51}$ NATO, AAP-6 (2009), p.2-I-6.

${ }^{52}$ L.K. Johnson, "Brick and Mortar for a Theory of Intelligence", Comparative Strategy, Iss.22 (2003), p. 1.

${ }^{53}$ DCAF "Intelligence Services" DCAF Backgrounder (2006), p.2
} 
state, territory, society and people against malicious acts - including terrorism, espionage, sabotage, subversion, extremism, organised crime, and drugs production/trafficking." ${ }^{54}$ This definition follows closely the official definition used by NATO, which defines security intelligence as "Intelligence on the identity, capabilities and intentions of hostile organizations or individuals who are or may be engaged in espionage, sabotage, subversion or terrorism." ${ }^{\text {"5 }}$ The emphasis on security intelligence is of the utmost importance because of the direct impact on society had by domestic intelligence, especially in societies undergoing political transformation.

Having defined what constitutes intelligence and security intelligence, there needs to be a clear conceptualization of what is meant by intelligence reform. Peter Gill classifies security intelligence services in three main categories that have different levels of political control and penetration of society. The first category represents the type of agency that can be found in a liberal democracy, which Gill refers to as a "Bureau of domestic intelligence". This is usually an agency with a mandate to gather and analyse information, under the control of the executive and which include review mechanisms. This ideal model is the ultimate aim of the reform process. The second general category is referred to as a "Political police", which supports the government and focuses on countering internal opposition. There is executive control of the intelligence service but little to no outside review. This type of security intelligence service is found in polities that are more authoritarian. Finally, the third category is the "Independent security state", which has a fully autonomous service with little to no control by the government, let

\footnotetext{
${ }^{54}$ G. Hannah, K.A. O'Brien and A, Rathmell "Intelligence and Security Legislation for Security Sector Reform" RAND Europe Technical Report (2005), p.6

${ }^{55}$ NATO, 2-S-4
} 
alone review from outside legislative bodies. ${ }^{56}$ This provides a good overall instrument to gauge the transition of security intelligence services, but it remains vague and limited.

These classifications will be used to broadly assess which categories apply to the Georgian and Serbian security and intelligence services at different stages of their development.

To complement Gill's general classification system, a number of items must be examined. Bruneau and Boraz put forward an institutional approach to intelligence reform based on the premise that the intelligence community is based on state activities and priorities, which are themselves based on institutions - wherein lies the power of the state. ${ }^{57}$ The authors note that in authoritarian regimes, there is an overlap between intelligence services, military intelligence and police services. Regimes rely on the security apparatus to keep an eye on, and neutralize if necessary, political opposition, causing an increase in the power and size of the security services to the point where they often become autonomous centres of power. The authors note that this made the security services seem more like political polices than domestic intelligence services. ${ }^{58}$ They put forward the argument that the two crucial elements to be able to undertake a comparative analysis of intelligence reform are democratic control and effectiveness. Democratic control is defined as:

[...] the sum of two parts - direction and oversight. Direction is civilian guidance to a nation's intelligence community with respect to its overall mission. [...] Oversight identifies the process a democratic government has in place to review all aspects of an

\footnotetext{
${ }^{56}$ P. Gill, Policing Politics: Security Intelligence and the Liberal Democratic State, (London, 1997), p. 82

${ }^{57}$ T.C. Bruneau \& S.C.Boraz, Reforming Intelligence : Obstacles to democratic control and effectivenyss, (Austin, 2003),p.2

${ }^{58}$ Ibid, pp. 12-13
} 
intelligence community's organization, budget, personnel and external control. ${ }^{59}$

These definitions underline the importance of a state's commitment to the process of intelligence reform for it to be successfully implemented.

In the quest to balance the imperatives of national security with that of transparency and accountability, no definitive solution has been found, even in stable liberal democratic states. Attempts at reforming intelligence practices and ensuring proper review and accountability have been taking place in Western states since the 1960s. In the United States, the Church Committee, to name but one of the investigative commissions set up by Congress, shed light on the unsavoury practices of the Central Intelligence Agency abroad, while in Canada, the MacDonald Commission's exposure of the tactics of the Royal Canadian Mounted Police led to the separation of security intelligence functions from those of law enforcement.

On the other hand, the objective of reform in Central and Eastern Europe was to increase control and effectiveness of the security and intelligence services, moving away from the role of a political police responsible for supporting the regime to one which has the protection of the state at its core. ${ }^{60}$ It has been noted that the priority of the new governments with regard to the security services was not to find professional but politically loyal staff. ${ }^{61}$ A critic of this view argues that after the end of the communist regimes in $\mathrm{CEE}$, attempts were made to purge the security services through lustration efforts. In turn it is argued that this led to a shortage of professional staff, the

\footnotetext{
${ }^{59}$ Ibid, p. 14

${ }^{60}$ L.L. Watts “Intelligence Reform in Europe's Emerging Democracies", Studies in Intelligence, Vol.41, Iss. 1,(2004), p.13

${ }^{61}$ Commission Européene pour la Démocratie et le Droit, Rapport sur le contrôle démocratique des Services de sécurité, (June 2007), p. 14
} 
politicization of the security services and the creation of legal frameworks for the exercise of security functions that were transplanted from other Western states without being adequately adapted to local realities. ${ }^{62}$ However, it must be noted that lustration efforts in the region wete never implemented uniformly and have had varying levels of success. Johnson notes that intelligence theory is mainly based on the Anglo-American experience and the author acknowledges that the results are therefore "more heuristic than definitive." ${ }^{63}$ This underlines the importance of tailoring reform to suit local realities and needs.

While the idea of establishing structures for the proper control and review of security intelligence services is laudable, concrete steps need to be undertaken to ensure adequate oversight. In this matter, there is an overall consensus on the varying means through which it can be achieved. Hannah et al consider that four key elements are necessary to implementing effective and accountable intelligence services, namely: a clearly defined mandate; executive control and coordination of the intelligence services; judicial oversight of the actions of the security services; and, parliamentary oversight and accountability. ${ }^{64}$ In parallel, Born and Leigh provide four levels of oversight: internal control from within the security and intelligence agencies; the role of the executive control; parliamentary review; and, the control provided by independent actors, such as state auditors and ombudsmen. ${ }^{65}$ These levels of oversight will be integrated within the

\footnotetext{
${ }^{62}$ V.D. Zorkin "Comments on Democratic Oversight of Special Services in Eastern Europe", Venice Commission. (May 2007), p.2

${ }^{63}$ Johnson, p. 2

${ }^{64}$ Hannah et al, p. 35

${ }^{65} \mathrm{H}$. Born \& I. Leigh Making Intelligence Accountable: Legal Standards and Best Practice for Oversight of Intelligence Agencies (Oslo: 2005), p.23
} 
theoretical framework that will be applied to the Serbian and Georgian security and intelligence services.

From these various levers of control and review, the present thesis will place the emphasis on institutional structures of the state, namely: the presence of legal frameworks defining the mandate and role of security intelligence services; the establishment of executive control over the security and intelligence services; and, finally, legislative review of the services. While using these broad elements as guidelines, the researcher will take into account local realities and variants to the methods that are put forward in the literature.

\section{Theoretical framework and approach}

The theoretical framework that this study will follow is mainly adapted from Edmunds's approach to security sector reform and will ground itself solidly in the elements present in the literature on security sector and intelligence reform. In order to fully analyse developments in the reform of the security and intelligence services in Georgia and Serbia, different levels of analysis will be used that are based on the work of Edmunds. Edmunds has developed a framework for analyzing security sector reform based on three levels, namely the political, organizational and international levels. The political level of analysis primarily addresses the relationship between the security sector and the political process. ${ }^{66}$ The organizational level looks at internal changes in the services; this typically means moving from protecting the regime to protecting society. ${ }^{67}$ It is within the examination of the organization level that the majority of the analysis on increased efficiency will occur, as well as a discussion of internal governmental

\footnotetext{
${ }^{66}$ Edmunds, SSR Transforming Societies, p. 27

${ }^{67}$ Ibid, p.34
} 
institutions that increase the efficiency of the security and intelligence services. Finally, the international level of analysis examines the role of the international community, the role of international and regional organizations in intelligence through security assistance, and the application of pre-conditionality and conditionality. ${ }^{68}$ The international level will be discussed within the political level for the purpose of this thesis.

The two main pillars of reform, namely accountability and efficiency, will be systematically examined at all three levels based on the common practices that are appropriate to these levels. These include the presence of a clear legal framework for the operations of the security services, executive control over the activities of the services, parliamentary review, judicial review, active interaction with civil society, and internal review mechanisms. In terms of increasing efficiency, elements such as working conditions, human resources reform, professionalization and further education programs, interagency cooperation and other such means will be examined when the information is publicly available. This is present in Edmunds' writings as second generation security sector reform, which will be combined with the conditions for increased effectiveness developed by Bruneau and Boraz. In a way, examining increasing efficiency is based on increased accountability, as a certain level of transparency is essential to studying this phenomenon.

In addition to these three levels of analysis, the historical development of the security services in Georgia and Serbia will be examined. This will provide context to the circumstances and missions that the security services undertook in the past and will highlight the traditions and legacies that can be adapted, as well as those that can hinder

\footnotetext{
${ }^{68}$ Ibid, p.42-43
} 
reform efforts. Gill's classification levels will also be used throughout the study of the security and intelligence services as a method of gauging the category in which the services are at a particular point in time. This multi-levelled theoretical approach will approach the subject from a variety of perspectives and aims to ensure a comprehensive review of intelligence reform in Georgia and Serbia. The elements to be reviewed that are comprised in each level will be introduced in their respective chapters.

\section{Division of the Thesis}

This thesis follows a thematic approach to intelligence reform, based on the levels of analysis that have already been described. Throughout this thesis, the theoretical model will be critically reviewed to ensure its applicability.

The first section will examine historical developments in Serbia and Georgia and provide a historical overview of the security and intelligence services in these two states, with an emphasis on developments from the end of Yugoslavia and of the USSR to the peaceful revolutions of 2000 and 2003 . This will illustrate the state of the security and intelligence services before democratic reform efforts began and provide the starting point for the subsequent analysis. The following sections will be developed according to Edmunds' approach, beginning with the political level. This section will examine political will and challenges to reform with an emphasis on the impact of national politics and the influence of governments on the services, and vice-versa. It will also examine the development of civilian democratic control over the security and intelligence services, through the legislative, executive and judicial branches of government. In addition to the traditional branches of government, the role and engagement of the international community will be examined. Subsequent to the examination of the political level of 
governance, the organizational level will analyze the developments within the security and intelligence services. This includes measures of internal control, coordination within the government apparatus, as well as measures to increase the efficiency of the services and second generation security sector reform. Together, these three levels will provide an overview of intelligence reform efforts in Georgia and Serbia. Adding a historical dimension to Edmunds' model will firmly ground the reform efforts within the wider historical realities in these countries. 


\section{Chapter II Historical legacies}

Any study of the security and intelligence services of a state must closely examine the historical development of these institutions. Historical legacies are often reflected in the institutional mentalities and daily operations of the services. The present section will provide an overview of the historical development of the security and intelligence services in Georgia and Serbia throughout the twentieth century. During most of the century, both of these now independent states were but provinces of larger political entities in which they played very different roles.

Georgia had a short period of independence following the end of the Russian Empire, before being re-absorbed by Soviet Russia. Although it was only a small republic within the USSR, Georgians did play an important role in the affairs of the state. During this time, the Georgian security services were but a republican-level division of the panSoviet Committee for State Security, or Komitet gosudarstvennoy bezopasnosti (KGB). They remained so until the dissolution of the Soviet Union, when Georgia proclaimed its independence and subsequently fell into civil war during the early 1990 s until the former Soviet Secretary for Foreign Affairs Eduard Shevardnadze ascended the presidency, presiding over a corrupt state until his ouster during the 2003 popular uprising that came

to be known as the Rose Revolution. Throughout this time, the role of the Georgian security and intelligence services was to protect the regime, a mission that has officially changed, as will be discussed in subsequent chapters. 
Serbia began the twentieth century as an independent kingdom best known for its brutal court intrigues and opposition to Austrian dominance in the Balkans. Following the First World War, Serbia emerged in a position of leadership that led to the creation of the Kingdom of Serbs, Croats and Slovenes in 1918. This multi-ethnic state remained a constitutional monarchy until 1929 when, following the assassination of Croatian nationalist leader Stjepan Radić, King Alexandar I declared a state of emergency and suspended the legislature. Under the royal dictatorship, a campaign of yugoslavisation was enforced by the secret police, which was at the forefront of the campaign against communism. Members of the Yugoslav communist party learned how to operate clandestinely with tight operational security, skills that would become essential during the Second World War. With the instauration of the Socialist Federal Republic of Yugoslavia (SFRY) Alexandar Ranković, the Serb that had been responsible for party security became responsible for the state security apparatus in which Serbs were omnipresent. During the years of the SFRY, the state security sector was in charge of protecting the communist party and hunting down its opponents domestically and abroad. Following the death of Josip Broz Tito, the republican security services began to eclipse the powers of the centre, a situation that allowed the Serbian security service to play the important role it did during the 1990 s civil war.

Historically, the security services in Georgia and Serbia were characterized by a mission of repression and protection of the regime. This left the services with a feeling of impunity and the sentiment that they are acting in the interest of national security, feelings that may challenge the post-authoritarian reform process. The historical attempts at reforming the security and intelligence services focused primarily at ensuring 
executive control and turning the services into instruments of the regime, with little or no legislative review. The following section will survey the history of the security services and the reform efforts that predated the democratic revolutions of 2000 and 2003 in Serbia and Georgia.

\section{Historical developments in Georgia}

\section{Revolution and initial independence}

Until its absorption in the Russian Empire during the nineteenth century, Georgia was an independent kingdom whose origins can be traced back to antiquity. Its strategic location at the crossroads of the Caucasus on the Silk Road made it a contested space for various regional powers. As a proudly independent-minded nation, the announcement of the abdication of Tsar Nicholas II in 1917 was greeted with joy in the streets of Tbilisi as revolutionaries took over government institutions, notably the local offices of the Russian secret police, arresting local gendarmes and members of the secret police. ${ }^{69}$ Indeed, following news of the revolution reaching Georgia, Tsarist police units and state administration disappeared while the Mensheviks, a political faction that was opposed to the Bolshevik's approach to power, increasingly dominated the Georgian political scene. ${ }^{70}$ During this time, the Bolsheviks were making progress in Russia. Following the October 1917 seizure of power in Petrograd by the Bolsheviks and fearing the consequences of the spread of Bolshevism, three Caucasian countries, comprising modern day Armenia, Azerbaijan and Georgia, united to form an independent federation.

\footnotetext{
${ }^{69}$ P. Hopkirk, On Secret Service East of Constantinople, (London: 1994), p.250

${ }^{70}$ Hopkirk, pp.192, 252
} 
However, this federal experience was to be short-lived as Georgia declared its independence in May 1918.

The revolution also prompted increased interest of foreign powers keen to control the region's strategic location and its natural resources. Germany had financed Georgian nationalist groups during the war to undermine the Russian position in the region and a military mission was sent to Georgia following the signing of the Brest-Litvosk treaty in $1918 .^{71}$ During these hectic days, Tbilisi was a centre of intrigue between German, Turkish, English and Russian spies operating without any check from the local government. The Turks were looking at increasing their gains in the region while the British wished to keep the Central Powers away from the region and the Russian Bolsheviks wished to regain control over the region.

During this period, the Georgian Lavrentiy Pavlovich Beria, who would come to play a major role in the region and throughout the USSR, joined the Bolshevik party. Following a successful infiltration of the Azerbaijani government as a member of the local secret police, or Cheka, before the Red Army's conquest of that country, Beria lobbied his superiors to be sent on an undercover mission in his native Georgia to gather information on the local Menshevik government. ${ }^{72}$ However, this mission was to be short-lived as Beria was captured by the Georgian authorities shortly after arriving in the country and was subsequently charged as a spy before his liberation due to the direct intervention of Sergei Kirov, then Soviet envoy to Georgia. ${ }^{73}$ This was only a temporary setback for Beria.

${ }^{71}$ D.M. Lang, A Modern History of Georgia, (London, 1962), pp.182-183

${ }^{72}$ A. Knight. Beria: Stalin's First Lieutenant, (Princeton, 1993), pp. 16-21

${ }^{73}$ T. Wittlin. Commissar: the Life and Death of Lavrentiy Pavlovich Beria, (New York, 1962), pp.49-51 


\section{Communist rule from 1921 to 1989}

Following a previous attempt, the Red Army invaded Georgia on 7 February 1921, which was soon followed by a Turkish invasion of western Georgia. Stuck between the two invading armies, Georgian military forces were quickly defeated and the Georgian Socialist Soviet Republic (SSR) was declared. ${ }^{74}$ The Georgian Cheka was established in the days following the invasion, overseeing the repression of local insurgents and pockets of resistance to Bolshevik rule while Beria used his leadership position to affirm his power in the Georgian and Transcaucasian security services, conveniently located in the same Tbilisi building. ${ }^{75}$ From this position of power, Beria consolidated his network of loyalists through the regional Communist structures. After becoming leader of the Georgian SSR and of the Transcaucasian region at the beginning of the thirties, Beria positioned his loyalists in key positions throughout the state and party apparatuses, building upon the networks he had established in the secret police. ${ }^{76}$ Meanwhile terror reigned within the Communist Party, with a great number of Party officials executed during the purges during most of the decade. After his appointment as head of the NKVD (Narodnyy komissariat vnutrennikh del, the latest name of the cheka) in 1938, Beria once again appointed loyalists to head regional and republican NKVDs, notably in Georgia and Leningrad. ${ }^{77}$ As head of the security services, Beria played a major role during the war years and during the onset of the Cold War, leading the Soviet

\footnotetext{
${ }^{74}$ Wittlin, pp.77-78

${ }^{75}$ Knight, Beria, pp.31-32

${ }^{76}$ R. Conquest. Inside Stalin's Secret Police: NKVD Politics 1936-1939, (Stan ford: 1985), p.88

${ }^{77}$ Knight, Beria, p.90
} 
efforts to acquire the atom bomb while the security service suffered a number of organizational transformations. ${ }^{78}$ This placed Beria in a central power position.

After Stalin's death in March 1953, Beria achieved initial predominance over the Soviet Politburo, the highest political council, before his arrest in June of that year. The military was at the forefront of the operation to arrest close associates of Beria in an effort to re-establish control politburo control, led by Nikita Khrushchev, over the security services. This particularly affected the Georgian KGB militarized under the leadership of General A.N. Inauri, who would remain in that position for three decades. ${ }^{79}$ A parallel can be drawn to the situation in Yugoslavia where the military took over the Yugoslav intelligence community following the fall of Ranković in 1966. Within Peter Gill's model, this period saw migration of the KGB from the level of "Independent Security State" in which the politburo had limited control over the operations of the security services, to that of a political police that returned to its initial mission as the shield of the communist party. Over the decades that followed, Georgians played a less prominent role in the Soviet security apparatus.

In 1965, Eduard Shevardnadze was appointed head of the Georgian Ministry of the Interior (MVD), a position he used to launch a campaign against corruption in the SSR that was so successful it led to the downfall of the Georgia First Secretary - and his replacement by Shevardnadze himself. ${ }^{80}$ Despite this change in local leadership, local KGB chair Inauri managed to remain in his position thanks in part to his loyalty to the

\footnotetext{
${ }^{78}$ Knight, Beria, p. 142

${ }^{79}$ A.W. Knight, The KGB : Police and Politics in the Soviet Union, (Boston, 1990),p. 47

${ }^{80}$ C. McGiffert Ekedahl \& M.A. Goodman, The Wars of Eduard Shevardnadze, (University Park, 1997), pp. $11-12$
} 
republic's leadership, while his superiors ignored corruption. ${ }^{81}$ During the late 1970 s, the KGB began to play a more predominant role in combating corruption and organized crime throughout the Soviet Union, in light of the poor performances of the MVDs and of the State Prosecution. It was suggested that then-KGB Chairman Yuri Andropov based his approach on the example of Georgia, which pioneered the use of the state security services to combat corruption. ${ }^{82}$ However, despite these efforts, Georgia remained a centre for the shadow economy, with Georgians playing a very active role in Soviet organized crime.

\section{Lead up to independence and civil wars 1989-1993}

There are several suggested explanations for the degeneration of the situation in Georgia following the end of the Soviet Union. A partial explanation can be found in the structure of Soviet federalism which "territorialized ethnicity" through the various levels of government. ${ }^{83}$ In Georgia, this policy led to the creation of the Abkhaz and Adjarian Autonomous Soviet Socialist Republics and of the South Ossetian Autonomous Oblast, which all housed ethnic minority groups and eventually became key problem areas following independence. These special statuses caused tensions with the majority Georgian population that became increasingly nationalistic during the final years of the Soviet Union.

In April 1989, following a request by the Georgian First Secretary approved by the Central Committee in Moscow, interior ministry troops were used to repress nationalist protesters after police forces refused to act, an operation that ended in the

\footnotetext{
${ }^{81}$ Knight, KGB, p. 163

${ }^{82}$ McGiffert Ekedah \& Goodman, p. 14

${ }^{83}$ C. Zürcher, P. Baev, Pavel \& J, Koehler. "Civil Wars in the Caucasus", in. P.Collier \& N. Sambonism , editors Understanding Civil War, Vol. 2, (Washington, 2005), p.260
} 
massacre of twenty Georgians. ${ }^{84}$ Indeed, the KGB and the Army were seen as pillars of the Soviet regime in Georgia and the local KGB was directly subordinated to the central authority in Moscow and less corruptible than the police was. Along with increasing nationalism came increasing resentment at the special status of South Ossetia and Abkhazia. A march on Tskhivali, the capital of South Ossetia, occurred in November 1989. While the initial protests were peaceful, bloodshed occurred following clashes between the Legion of Georgian Hawks, a nationalist militia, and Soviet MVD troops. ${ }^{85}$ These actions infuriated Georgian nationalists who increased the pressure for independence.

In addition to the ambient nationalism and ethnic tensions, it has been argued that the causes of the conflict that took place in post-communist Georgia can be found in "the anomalies and distortions of its own society, political institution and elites" with sources in the shadow economy and corruption. ${ }^{86}$ Although Shevardnadze had appeared to curb corruption during his tenure as First Secretary, in reality clan-based corruption increased which led to the economic corruption of the late 1980s and the submersion of the "official economy" in the first years of independence. ${ }^{87}$ The underground economy would prove to be a fertile breeding ground for members of the various militia and paramilitary groups that emerged following independence.

Mirroring events in other Soviet republics, parliamentary elections occurred in November 1990 and nationalist dissident Zviad Gamsakhurdia was elected Chairman of

\footnotetext{
${ }^{84}$ J.M. Waller,Secret Empire: The KGB in Russia Today, (Boulder, 1994), pp.54,154

Gordadzé, T. (2003). "Police et formation de l'État en Géorgie post-Communiste" in Favarel-Gorrigues, Gilles (ed). 193-232, pp.205-206

${ }^{85}$ Baev, p. 131

${ }^{86}$ P.K. Baev, 'Civil Wars in Georgia: Corruption Breeds Violence' in J. Koehler \& C. Zürcher, editors, Potentials of Disorder, (Mancheste, 2003), p.128

${ }^{87}$ Baev, p. 129
} 
Parliament before his election to the presidency the next year. ${ }^{88}$ In March 1991, with 90 percent of the population voting, 98 percent of the population voted in favour of independence and Georgia unilaterally declared its independence on 9 April $1991 .^{89}$ This was not recognized by the international community until the official dissolution of the Soviet Union in December of that year.

As a central condition for effective governance, the new republic began to establish institutions that would guarantee its independence. The local KGB formed the basis for the new Service for Information and Intelligence created in 1991. In addition, a National Guard created earlier that year under the command of Tengiz Kitovni, had to rely on self-armed and self-fed volunteers and built his forces through "soft" extortion. ${ }^{90}$ The government had little control over this unit, which was first and foremost loyal to its commander, as subsequent events would prove. In addition to this officially sanctioned paramilitary force, a number of other militia units appeared on the horizon. One of the most important militias to appear during this time was the Mkhedrioni, named after medieval Georgian knights. This militia had strong links with Georgian organized crime in Moscow, and assembled under the leadership of the playwright and criminal Jaba Iosaliani. ${ }^{91}$ This militia also operated outside government control, which at that time consisted of conflicting personalities basing themselves upon their own power bases to ensure predominance.

\footnotetext{
${ }^{88}$ C. Cosmon,, R. Denber, J. Laber. "Conflict in Georgia: Human Rights Violations by the Government of Zvia Gamsakhurdia". Helsinki Watch News, Vol.3 Iss.16, (27 December 1991), p.3

${ }^{89}$ Ibid

${ }^{90} \overline{B a e v}$, p. 131

${ }^{91}$ Ibid
} 
In August 1991, President Gamsakhurdia took a placid stance towards the attempted coup in Moscow, causing the resignation of Kitovani. ${ }^{92}$ As a result, the President ordered the National Guard to disarm, which it refused to do. Following this unsuccessful attempt at establishing central control over the paramilitary unit, Kitovani led an estimated five hundred troops into Tbilisi. During the end of December 1991, the National Guard laid siege to the government and forced Gamsakhurdia to flee in early January 1991. While they were victorious for the moment, conflicting interests would plant the seeds of discord between these two organizations. Following the seizure of power by these two warlords, Eduard Shevardnadze returned to Georgia as a member of a governing troika, also known as the State Council, bringing some legitimacy to the new government.

\section{Consolidation of power under Shevardnadze}

While Shevardnadze was initially only one member of the State Council, he quickly achieved a predominant position in Georgia. Elections held during the fall of 1992 provided Shevardnadze with a strong personal mandate as leader of the country, although the resulting legislature was deeply divided. In addition to this political power, Shevardnadze began to bring the two main militias under government control. The National Guard was placed under the control of the developing Georgian military while the Mkhredrioni were formally appropriated by the MVD. ${ }^{93}$ These were but the first steps in establishing executive control over the various forces that constructed the Georgian security sector, as the conflicts engulfing the small country demonstrated the limited control over these militias. During this time, the small intelligence service reported

\footnotetext{
${ }^{92}$ Cosmon et al., p.4

${ }^{93}$ Baev, p. 133
} 
directly to Shevardnadze, although its effectiveness during these chaotic times is nearly impossible to assess.

While Shevardnadze was consolidating his personal power over the various factions within Tbilisi, the conflict in South Ossetia continued following the region's unilateral declaration of independence in September $1990 .{ }^{94}$ In January 1991, during Gamsakhurdia's tenure of power, between three and four thousand Georgian volunteers were present in South Ossetia. ${ }^{95}$ This conflict brewed until a ceasefire was agreed upon in June 1992, with the instauration [creation] of a joint peacekeeping force in South Ossetia comprising Russian, Georgian and Ossetian troops. ${ }^{96}$ However, there was only a short respite in the conflict as following the unilateral declaration of independence by Abkhazia in August 1992, the National Guard took the initiative to move into Abkhazia in mid-August 1992 and it is unclear whether Shevardnadze controlled these forces from the beginning. ${ }^{97}$ As the war dragged on and Georgian forces were repelled from Abkhazia, Shevardnadze had Kitovani replaced. Simultaneously, a pro-Gamsakhurdia uprising took place in western Georgia and in desperation Shevardnadze requested a Russian intervention in exchange for Georgian membership in the CIS. ${ }^{98}$ This added Russian armed forces to other security forces operating in Georgia, as Russian influence continued well after the end of the USSR.

Shevardnadze's decision to join the CIS in 1993 caused the first leader of the Intelligence and Information Bureau, the new appellation of the Service for Information and Intelligence, to resign while Shevardnadze appointed loyalists in the power

\footnotetext{
${ }^{94}$ Cosmon et al., p. 17 .

${ }^{95}$ Ibid

${ }^{90}$ Zürcher et al., p.268.

${ }^{97}$ Ibid , p. 169

${ }^{98}$ Baev, p. 133
} 
ministries, most of who came from the Soviet Red Army and the KGB. ${ }^{99}$ Following these events, the intelligence service transformed and expanded to form the Ministry for State Security (MSS) in October 1993, under the leadership of former KGB officer Igor Giorgadze. ${ }^{100}$ This merger created a security intelligence service that had the dual role of providing intelligence and incorporated the operations division of the Ministry of the Interior. ${ }^{101}$ This combination permitted the MSS to collect intelligence and act forcibly upon it and provided the central government with a powerful tool that helped it restore its monopoly on violence.

During the Shevardnadze period, the security sector consisted of a great number of agencies with overlapping responsibilities and unclear mandates, which played into Shevardnadze's strategy of ensuring that power was not centralized. This strategy was first used in the struggle against the Zviadist rebellion in western Georgia when he relied on the Mkhedroni, before using the security services to clamp down on the militias, then using the Interior Ministry to crack down on the security services. This strategy created a feeling that the services had to defend their own interests and preserve their positions. ${ }^{102}$ Darchiashvili argues that Shevardnadze's policy of decentralizing power ministries to balance each other off worked out and created the basis for further institutionalization. ${ }^{103}$ The police were consolidated as the state's main coercive force with the beginning of a clamp down on smaller paramilitary groups before moving on to the Mkhedrioni. In 1994 the Mkhedrioni were transformed into a Rescue Corps before being ordered to disarm in

\footnotetext{
${ }^{99} \mathrm{~J}$. Wheatley. Georgia from National Awakening to Rose Revolution, (Aldershot, 2005), p.84-85

${ }^{100}$ Wheatly, p.87

${ }^{101}$ Georgian Radio, "Information and Intelligence Service promoted to Security Ministry", BBC Summary of World Broadcasts, (15 October 1993).

${ }^{102}$ Gordadzé, p. 210

${ }^{103}$ Darchiashvili, D. "Georgian Defence Policy and Military Reform", 117-151, in B. Coppieters \& R. Legvold, editors, Statehood and Security, (Cambridge, 2005). pp. 129-130
} 
May 1995, leading to further tensions between Ioseliani and Shevardnadze. ${ }^{104}$ The Mkhedrioni formed an alliance with the Minister for State Security, Igor Giorgadze, whose deputy was a former Mkhedrioni and minister of internal affairs. Following an assassination attempt on 29 August 1995, Shevardnadze claimed that this was a coup attempt and severely criticized the work of the Ministry for State Security, dismissing Giorgadze and his deputy. ${ }^{105}$ In the weeks that followed the assassination attempt, the Mkhedrioni legacy unit, the Georgian Rescue Corps, was formally disbanded following accusations of having been infiltrated by criminal elements and having participated in the attack. ${ }^{106}$ Giorgadze and Khachischvili were later accused of masterminding the assassination attempt and Giorgadze fled the country. ${ }^{107}$ During the years that followed, Giorgadze would often be accused of plotting against the Shevernadze government from exile, with the Russians often being accused of harbouring him, and was even accused of being their spy. ${ }^{108}$ This would not be the last attempt on Shevardnadze's life. There was an assassination attempt on Shevardnadze when his convoy was attacked in February 1998. Two bodyguards were killed and there were many indications that the attack was too well planned to have been planned and carried out by Georgians. ${ }^{109}$ These attempts were an occasion for the government to crack down on opposition and continue to wave the spectre of foreign subversion.

\footnotetext{
${ }^{104}$ Wheatly, pp.86-87

${ }^{105}$ Georgian TV, "Shevardnadze sacks Security Service head; reveals further details on attack", $B B C$ Summary of World Broadcasts, (5 September 1995).

${ }^{106}$ Georgian Radio, "Shevardnadze news conference: Rescue Corps was 'haven for criminals", $B B C$ Summary of World Broadcasts, (3 October 1995).

${ }^{107}$ Wheatly, p. 87

${ }^{108}$ Interfax "Georgia: Security Minister Says Former Security Chiefs Were Spies", (19 July 1996).

109 A. Mikadze, "Midnight Terrorism", Moscow News, (19 February 1998).
} 


\section{Early reform attempts and their challenges}

There were a number of early attempts to reform the security sector in Georgia. As previously mentioned, the priority in the early 1990s was the establishment of executive control over the disparate elements of the security sector. In terms of executive control over the intelligence and security services, the State Chancellery was the main centre of power in government, a fact accentuated by the absence of a Prime Minister, giving a larger role to the presidential administration. The National Security Council (NSC) played a crucial role as an organ in charge of command and control. The secretary of the NSC was Nugzar Sajaia from 1996 until his suicide in 2002, and as such was one of the most powerful figures of the regime. ${ }^{110}$ Although formal structures had been established, one challenge to reform was the fact that personal relationships, and not institutional processes, made the system function. As a consequence, the security and intelligence services would often be used for political purposes. For example, during fall 2001, a botched raid against independent television broadcaster Rustavi-2, led to wider protests and the fall of the government. At this time, State Security Minister Kutateladze resigned and was replaced by Valeri Khaburdzania, a man who had experience in the department between 1992 and 1997. ${ }^{11}$ Khaburdzania would remain minister until the Rose Revolution, after which he was appointed secretary to the NSC.

In July 1997, acting State Security minister Jemal Gakhokidze announced reforms in the Ministry for State Security, a core element of which was the separation of intelligence and counter-intelligence, as well as the creation of a unit responsible for

\footnotetext{
${ }^{110}$ Wheatly, pp.110-111

${ }^{11}$ Georgian TV, "New Georgian security minister nominated", BBC Worldwide Monitoring, (14 November 2001).
} 
combating contraband and terrorism. ${ }^{112}$ These reforms were implemented rapidly as a new Intelligence Department was created, an independent entity that still answered to the Minister for State Security (MSS) and reported to the president; its mission was both domestic and foreign intelligence analysis. ${ }^{113}$ A new legal framework for intelligence operations replaced Soviet-era legislation and presidential decrees with the introduction of a law on intelligence in March 1999. However, parliamentary oversight of the security sector was weak and while the minister was accountable to Parliament, it did not provide oversight over the agencies of the security sector, nor of the National Security Council. ${ }^{114}$ These efforts led to an incomplete framework for the democratic control of the intelligence services, although these half-measure surpass the complete lack of reform in Milošević’s Serbia.

In addition to the lack of proper democratic control, budgetary restrictions hindered the effectiveness of the security and intelligence services. Within the Ministry for State Security, lack of pay led to the departure of 800 employees between 1999 and 2000, although the MSS still had a staff of 5,000. ${ }^{115}$ The average monthly salary for employees was 80 Lari per month, or about 40 USD. ${ }^{116}$ With such low salaries, it is understandable that corruption flourished. It was estimated that half of international

\footnotetext{
112 Interfax, "Security chief announces "global reform" in ministry", BBC Summary of World Broadcasts, (24 July 1997).

${ }^{113}$ Prime-News, "Intelligence chief optimistic about his department's activities", BBC Summary of World Broadcasts, (14 October 1997).

R.L. Larsson, Georgia's Search for Security: An Analysis of Georgia's National Security Structures and International Cooperation, Occasional Paper \# 1, 2003., p.17

${ }^{114}$ Darchiashvili, p. 139

${ }^{115}$ Prime-News, "Georgian security chief saying unpaid staff leaving ministry", $B B C$ Worldwide Monitoring, (18 May 2000).

${ }^{116}$ Prime-News "Georgian security chief admits info leak from ministry", BBC Summary of World Broadcasts, (12 February 2003).
} 
donor contributions vanished before being put to use. ${ }^{117}$ Proper efforts to restore professionalism to the security services would remain stalled until proper remuneration was provided to their employees.

There had been limited cooperation between Georgian and Western intelligence services prior to the Rose Revolution. During this time, the security sector reform process lacked local ownership and was heavily reliant on foreign expertise, especially through the recently created International Security Advisory Board, and the recommendations were not sufficiently adapted to local realities. Indeed, there was a lack of local civilian expertise in security issues. ${ }^{118}$ Cooperation between the Georgian Ministry for State Security and the Central Intelligence Agency went back to 1993, with both organizations cooperating on counter-terrorism and counter-narcotics operations. ${ }^{119}$ This continued throughout the tenure of the Shevardnadze government; in March 2000 then CIA director George Tenet visited Tbilisi, in a reunion that led to increased information sharing and cooperation between the services. ${ }^{120}$ Cooperation with foreign intelligence services also occurred in dealing with the issue of the Pankisi gorge, a region of northern Georgia that was often pointed out as a safe haven for Islamist groups fighting Russia in the northern Caucasus. Although any such presence was denied at first, there was eventually an acknowledgement by Georgian authorities that Chechen rebels, as well as other Islamic

\footnotetext{
${ }^{117}$ A. Fritz, "Status report on Security Sector Governance in Georgia", in PfP Consortium of Defence Academies and Security Studies Institutes, Security Sector Governance in Southern Caucasus - Challenges and Visions, (Vienna and Geneva, 2004).

${ }^{118} \underline{\text { Ibid }}$

119 Georgian Radio, "Security Ministry to cooperate with CIA", BBC Summary of World Broadcasts, (22 October 1993).

${ }^{120}$ AVN, "Georgia ready to accord CIA 'most favoured' treatment", BBC Summary of World Broadcasts, (29 March 2000).
} 
terrorist groups, were hiding in the Pankisi region. ${ }^{121}$ This situation partly explains the early international support for Georgian security forces. There was international assistance from western countries as well as from Russia to act towards this as the Georgian security services discussed their approach with Russian forces. ${ }^{122}$ Georgian security forces moved into the valley during summer 2002 in an operation that dislodged the majority of foreign forces, although Shevardnadze did admit that some foreign fighters were still present in the area. ${ }^{123}$ International support for and cooperation with the Georgian security sector would grow following the overthrow of the Shevardnadze government in the Rose Revolution.

While this period saw the instauration of effective executive control over the security sector, this by no means meant the consolidation of appropriate democratic control, and there remained several impediments to proper reform. Larsson viewed problems during the Shevardnadze era based on the staff lingering from the Soviet era, generational gaps among the personnel and the need for new laws. He argued in favour of democratic, and not only civilian, control of the security sector. ${ }^{124}$ Additional recommendations included the need to professionalize the services instead of relying on nepotism and a clear and consistent reform agenda because of the limits of what can be achieved on an ad hoc basis. ${ }^{125}$ As such, the reform process that had begun during the Shevardnadze era remained incomplete.

\footnotetext{
${ }^{121}$ Georgian TV, "Georgian security minister says Chechen field commander may be in Pankisi gorge", $B B C$ Worldwide Monitoring, (6 February 2002).

${ }_{122}$ NTV, "Georgian and Russian security services meet to discuss tactics", BBC Summary of World Broadcasts, (5 March 2002).

${ }^{123}$ Rustavi-2, "Georgia admits foreign fighters are still in the Pankisi Gorge", BBC Summary of World Broadcasts, (21 October 2002).

${ }^{124}$ Larsson, p.19

${ }^{125}$ Larsson, pp.22-23
} 


\section{The Rose Revolution}

Towards the end of the 1990s, political opposition became more organized, and a first triumph came during the June 2002 local elections which saw an opposition victory in Tbilisi, an important event in and of itself because the capital city holds close to a third of the country's population. A presidential election was called for November 2003 and during the presidential campaign, opposition leader Mikhail Saakashvili brought new, modern strategies to the electoral process. ${ }^{126}$ In parallel to electoral efforts, a number of opposition groups, notably the youth group Kmara! (Enough!), established close ties with the Serbian NGO Otpor, one of the main opposition forces that had toppled Slobodan Milošević in October $2000 .^{127}$ This can partly explain the similarities between the Rose Revolution and the October 5 Revolution in Serbia which occurred following blatant electoral fraud and resulted in a popular overthrow of the government. As was the case in Serbia, despite a certain level of public acceptance of electoral fraud in Georgia, the spark for the revolution came when the existing government blatantly ignored the results and published false results. Protests were relatively small for the majority of the opposition. Saakashvili himself often drew parallels with the revolution in Serbia, especially between Kmara and Otpor.

The breaking point was reached when the election in Adjara reportedly went overwhelmingly in support of Shevardnadze. Following this announcement, thousands of protestors assembled in Tbilisi calling for his resignation. Originally, a state of emergency was declared at the urging of the Minister of the Interior but it was doomed to fail because the government did not have effective control of the security services and

${ }^{126}$ C.H. Fairbanks, C.H, “Georgia's Rose Revolution" Journal of Democracy, 15(2), (April 2004), p.114

${ }^{127}$ Ibid, p.115 
police. ${ }^{128}$ Indeed, it has been suggested that the main reason for the success of the Rose Revolution was the fragmentation of the political elites and the lack of credibility of the threat of use of force. ${ }^{129}$ Saakashvili has stated that at this point in time, counterintelligence forces had defected to the protestors' side and were keeping surveillance on the government and Shevardnadze, who had acknowledged that a majority of the security forces supported the opposition. ${ }^{130}$ Indeed, there were a number of events in which the leadership appeared disjointed. On Friday, 21 November 2003, the Secretary of the NSC made a public statement declaring that Shevardnadze ought to annul the election result and dismiss those responsible for rigging the elections. ${ }^{131}$ The most obvious example of the end of the regime occurred when police and internal military forces, after discussions with protestors, allowed the storming of the parliament buildings on Saturday, 22 November 2003. With the security forces remaining passive, the protestors were able to storm the Parliament buildings, causing Shevardnadze to flee to Adjara. Adding to the symbolism of the moment, Saakashvili distributed roses to the protestors who had stormed the legislature, thus providing the popular revolution with its most recognizable symbol. During the following days, both Russian and American envoys were sent to Georgia to deal with both the government and the opposition, culminating in Shevardnadze's resignation on 23 November 2003.

Following Sheverdnadze's resignation, the Chairman of Parliament became the acting president until the January 2004 elections that were held to replace the fraudulent November elections. The results led to a Saakashvili victory with over ninety-five percent

\footnotetext{
${ }^{128}$ Z. Karumidze \& J. Wetsch. Enough!: The Rose Revolution in Georgia. (New York, 2005), p. 18

${ }^{129}$ Wait, p. 4

${ }^{130}$ Karumidze \& Wetsch, p.30

${ }^{131} \underline{\text { Ibid, }}$ p.13
} 
of the votes. ${ }^{132}$ In this period, a number of senior government officials resigned as well, either because of pressure from the new government or because they were unwilling to work under the new leadership. ${ }^{133}$ This included the replacement of the head of intelligence in Georgia and marked the beginning of more intensive reform efforts.

\section{The shadows of history: Historical developments in Serbia}

\section{The First Yugoslavia and the Second World War}

The history of Serbia during the twentieth century is inseparable from that of multiethnic Yugoslavia, created from the ashes of the Habsburg Empire and ruled by the independent kingdom of Serbia following the carnage of the First World War. Increasing tensions between the nationalities, mainly between Serbs and Croats, throughout the 1920 s led to the murder of three Croat deputies by a Serb Radical deputy during a session of parliament in June 1928. Because of the ensuing political crisis, King Alexandar abolished the constitution and suspended parliament, creating a Royal Dictatorship. While the 1920s emphasized Serbian dominance, the royal dictatorship promoted Yugoslavism as a new national ideology, which brought a 'melting-pot' approach to nationality in the kingdom. ${ }^{134}$ There was increased ideological surveillance aimed at ensuring support for Yugoslavism to enforce this new vision, achieved through police presence at all public meetings. ${ }^{135}$ This surveillance was proactive, with citizens expected to promote Yugoslavism and passivity perceived as a form of subversion. This

\footnotetext{
${ }^{1.32}$ Fairbanks, p. 117

${ }^{133}$ International Crisis Group (ICG), "Georgia: What Now?" International Crisis Group, Europe Report 151, (3 December 2003), p. 12

${ }^{134}$ V. Pavloviç. "La mémoire et l'identité nationale: la mémoire de la grande guerre en Serbie" Guerres mondiales et conflits contemporain $n_{2}$ n.228, (2007/4), pp.52-54.

${ }^{135} \mathrm{C}$. Axboe Nielsen, "Policing Yugoslavism: Surveillance, Denunciations, and Ideology during King Aleksandar's Dictatorship, 1929-1934" East European Politics and Societies, Vol.23, n.1, (February 2009), p.42
} 
surveillance system, based on police informers, also integrated the surveillance of border areas by border guards, gendarmerie and military intelligence. ${ }^{136}$ From the early twentieth century, military intelligence has played an important role in the Serbian and Yugoslav security and intelligence community.

National cohesiveness was promoted through a number of institutions as well. As a more positive force, the army played an important role as a national institution ensuring common purpose. ${ }^{137}$ As was later the case to some degree in communist Yugoslavia, the judicial apparatus also played a role in enforcing Yugoslavism. Special importance was given to inter-ethnic crimes and a new form of punishment was formed through the use of 'internal exile', during which minor offenders would be forced to live in a different part of the country. ${ }^{138}$ Following the 1934 assassination of King Alexander in Marseilles, there was a relaxation of the Royal Dictatorship, with the first parliamentary elections held in 1935. During the remainder of the 1930s, the Yugoslav police and military intelligence would play an important role in repressing not only communist groups, but also Macedonian revolutionaries and the fascist Croat Ustaše.

Although invaded in 1940, Yugoslav resistance began in earnest following the Axis invasion of the Soviet Union, when the Communist Party of Yugoslavia began to attack the occupying forces. Much as was the case in the first Yugoslavia following the First World War, the second Yugoslavia would develop a national myth around the Partisan war. ${ }^{139}$ While resistance was furiously divided between communist and monarchist forces, Yugoslavia would be the only country in Central and Eastern Europe

\footnotetext{
${ }^{136}$ Axboe Nielsen, p.48

${ }^{137}$ Pavloviç, p.56.

${ }_{138}$ Axboe Nielsen, p.43

${ }^{139}$ Pavloviç, p. 56.
} 
to successfully liberate itself without relying on the Soviet Red Army, placing the newly established Socialist Federal Republic of Yugoslavia (SFRY) in a relative position of force and independence vis-à-vis the Soviet Union.

\section{Post-War Era: 1945 to 1966}

The origins of the communist security services come from years of experience in the underground existence of the Yugoslav communist party during the interwar period and then during the Nazi occupation. There was a refinement of police surveillance in its actions against the communist party with the gendarmerie used as the main tool against the communist party. ${ }^{140}$ During the course of the Second World War, the political security services of the communist party were created under the leadership of Aleksandar Ranković and Svetislav Stefanović, a duo that would remain influential in the Yugoslav security apparatus for the two following decades. ${ }^{141}$ Ranković was originally a Serbian peasant and tailor's son, with "shrewd common sense, anachronistic combination of simplicity and subtlety and suspicion [...]" ${ }^{142}$ These traits would all be put to use as the Communist Party began to consolidate its power over Yugoslavia. The Department for the Protection of the People (Odeljenje za zaštitu naroda, or OZNa), was created in 1944. Following the war, the priority for the organization was to subdue domestic enemies and consolidate the position of the Communist Party of Yugoslavia, and, as oft-quoted: "strike terror into the hearts of those that don't support this sort of Yugoslavia". ${ }^{143}$ This included the liquidation of opponents, made easier by the "completeness of the

\footnotetext{
${ }^{140}$ Axboe Nielsen, p.37

${ }^{141}$ M. Milivojevic "The Role of the Yugoslav Intelligence and Security Community" in edited by J.B. Allcock, J. J. Horton, and M. Milivojevic, editors, Yugoslavia in Transition, (New York, 1992), p.200

${ }^{142}$ D. Rusinow. The Yugoslav Experiment 1948-1974 (London, 1977), p.156

${ }^{14.3}$ J.R. Lampe, Yugoslavia as History, (Cambridge, 2000), p.227
} 
communist take-over" as well as the discredited and politically weak nature of the opposition. ${ }^{144}$ Initially, the security service was the enforcer of collectivization until this policy was abandoned. ${ }^{145}$ The post-war security service included strong paramilitary components to quell the centres of opposition to communist rule. ${ }^{146}$ During the early post-war period, it was estimated that 250,000 people died as a result of the repression, whereas some have put the figure as high as $1,000,000 .{ }^{147}$ Lampe puts the range of executions from 1946-47 in the five-digits, while the number present in camps is estimated at in the range of six figures. ${ }^{148}$ The opposition to the new rule was strongest in Kosovo, where there was an armed rebellion against the Partisans, which required an intervention of the Army and OZNa with more than 30,000 to quell the revolt, which did not happen before the summer of $1945 .^{149}$ Throughout this period both OZNa and its successor, the Uprava državne bezbednosti (UDBa), created in March 1946, were staffed primarily by Serbs and Montenegrins.

During the lead up to the 1948 break with the Soviet Union, the Soviet secret service made attempts to recruit a large network of local informants, activities that could not have escaped the UDBa's agents. ${ }^{150}$ Soviet intelligence continually made efforts to infiltrate Yugoslavia, focusing on the communist party and the army and reaching into the Yugoslav Politburo and military high command. ${ }^{151}$ In addition, the Soviet Union increased its propaganda operations against Yugoslavia while the UDBa deployed

\footnotetext{
${ }^{144}$ Rusinow, p. 15

${ }^{145}$ Ibid, p. 251

146 Ibid, p. 238

${ }_{147}$ Milivojević, Role of Yugoslav Intelligence, p.206

${ }^{148}$ Ibid, p.238

149 Ibid, p.228

${ }_{150}$ Ibid, p. 247

${ }^{151}$ Milivojević, Role of Yugoslav Intelligence, p.206
} 
considerable effort to counter these moves. ${ }^{152}$ This justified the focus on countering Soviet influence by the Yugoslav security services. Communist party members suspected of being too close to the Soviets were arrested, in some cases shot, with increasing intensity. ${ }^{153}$ The number of alleged Soviet sympathisers arrested reached an estimated 14,000. ${ }^{154}$ Following these years of terror, Ranković admitted that ordinary crimes had been converted into political crimes in many unjustified cases. ${ }^{155}$ In 1951 , as part of a struggle for increased legality and to eliminate extra-judicial operations, Ranković and the UDBa began to play a more discreet role, becoming fully civilian with the "stripping" of national security troops, national guards, prison guards and VIP protection. ${ }^{156} \mathrm{An}$ additional change in the nomenclature occurred in 1954, when the UDBa became the Služba državne bezbednosti (SDB).

\section{The fall of Rankovic and its aftermath}

At this point, the security service under Ranković had achieved important autonomy from the government and formed a power base with which he led the charge against party policies. Ranković's opposition to the burgeoning reform movement within the Communist Party created a strong coalition of liberals that wished to remove him from power. The new Minister of the Interior, Milan Mišković, kept in the dark by the SDB, requested that Yugoslav Military Intelligence (Kontraobaveštajna služba, or KOS), headed by his brother, monitor SDB operations. ${ }^{157}$ As a result, the electronic surveillance of high party officials by the security service, including Tito's private residence, was

\footnotetext{
${ }^{152}$ Rusinow, p.43

${ }^{153}$ Lampe, pp. 249-252

154 Rusinow, p.30

${ }^{155}$ Ibid, p. 15

${ }_{156}$ Milivojević, Role of Yugoslav Intelligence, $p 208$

${ }^{157}$ Rusinow, p. 184
} 
uncovered. ${ }^{158}$ While the official argument reflects that the SDB was behind Tito's surveillance, it has been argued that the wiretapping of Tito's personal quarters was done by his Tito's military aide-de-camp, who was strongly suspected of belonging to KOS and who dismissed shortly after the incident. ${ }^{159}$ An alternative theory is that Tito himself had created this plot to rebalance the rapport de force within a security apparatus dominated by Rankovic. ${ }^{160}$ These allegations led to a severe examination of the role of the SDB in both society and the party itself.

A party commission tasked with investigating these claims confronted Ranković and Stefanović at the Central Committee's July 1966 plenum in Brioni. Although they denied playing a role in the wire-tapping, the commission focused on their overall role and behaviour of the SDB. Rusinow quotes Tito as stating: "Does this not somehow remind you of what was going on under Stalin? [...] [The Central and Executive Committees] had made a mistake in having virtually left our Security Service to go its way for more than twenty years." ${ }^{161}$ An additional commission was established to reign in the SDB's influence over other branches of government, notably the Service for Information and Documentation (SID), the agency responsible for foreign intelligence that was under the purview of the Foreign Ministry. ${ }^{162}$ The SID would remain independent of influence from its domestic counterpart until the Milošević era.

Following the plenum, there were public denunciations of the SDB, which was portrayed as an 'old-boys network' of Partisans, dabbling in smuggling, kickbacks and

\footnotetext{
${ }^{158}$ Lampe, p.290, Rusinow, p.185

${ }^{159}$ Milivojević, Role of Yugoslav Intelligence, $\mathrm{p} 210$

${ }^{160}$ Ibid

${ }^{161}$ Rusinow, p. 187

${ }^{162}$ Central Intelligence Agency, "Yugoslavia - The Fall of Rankovic" Current Intelligence Weekly Special Report, 5 (August 1966),p. 5

Milivojević, Role of Yugoslav Intelligence, p.216
} 
corruption. Their ethnic prejudices and the brutal methods used in Kosovo were also denounced. ${ }^{163}$ In contrast to the purge of Beria, the fall of Ranković caused not only the replacement of the head of the security service, but the discredit of the entire organization until its eventual rehabilitation in $1969 .{ }^{164}$ These events led to a number of changes in the Yugoslav intelligence community, namely the separation of the service from direct association with the party and the creation of a mandate that limited the SDB's activities to countering "the class enemy and threats from abroad and were to be placed under the supervision of representative bodies." ${ }^{165}$ In addition, political functionaries were appointed in executive positions in the SDB. These nominations firmly re-established party control over the security services and demonstrate the method through which executive control was achieved during the communist period. With the party reigning in the SDB, the separation of the SDB and the party was more theoretical than real as its main mission remained the defence of the party while the new mandate remained vague. Milivojević argues that the ensuing military predominance in the Yugoslav security and intelligence community laid the groundwork for the increasing influence of the military in society in the late 1970s and throughout the 1980s. ${ }^{166}$

The events that surrounded the fall of Ranković highlight that some elements of intelligence reform may be present under systems other than democracy. Following discoveries that the SDB had acted out-of-bounds, the Yugoslav leadership moved to firmly re-establish its control over the security apparatus, partly through increased party oversight and partly through the act of balancing different sections of the security and

\footnotetext{
${ }^{163}$ Rusinow, pp. $187-188$

${ }^{164}$ Rusinow, p. 188

${ }^{165}$ Ibid, p. 190

${ }^{166}$ Milivojević, Role of Yugoslav Intelligence, p.212
} 
intelligence community against each other. While the military gained predominance in the intelligence community following these events, the balance would swing back in favour of the SDB, although this time to the Serbian republican SDB, under Milošević. As was the case in the Soviet Union following the end of Beria, the reigning in of the security service transformed the SDB from an agency that can be classified in Peter Gill's model as an "Independent Security State" to a more subdued "Political Police" force under the control of the regime.

\section{Yugoslavia's final decade}

Until his death in 1980, Tito kept abreast of intelligence developments through his personal secretariat, but it is unclear whether this informal institution continued to exist under the new-style rotating presidency introduced in the 1974 constitution. This new constitution gave the constituent republics increased autonomy which was reflected throughout Yugoslavia's bureaucracy, although this was far less pronounced in the JNA and in the security apparatus, as the SDB continued to report to the Ministry of the Interior (MUP) and KOS to the JNA. ${ }^{167}$

SDB surveillance remained active domestically and abroad through the precise targeting of influential opponents both at home and abroad. ${ }^{168}$ In addition to their role in gaining foreign intelligence, the SDB and SID had a role in monitoring and disrupting opposition in the diasporas worldwide, including a unit responsible for assassinating vocal opponents of the regime. An estimated seventy-two assassinations of political

\footnotetext{
${ }^{167}$ Babović, B. "Analysis of regulation regarding responsibility for control of the interior ministry of the republic of Serbia", Case No. IT-02-54-T, International Criminal Tribunal for the former-Yugoslavia, (25 April 2003), (paragraphe 10).

${ }^{168}$ Milivojević, Role of Yugoslav Intelligence, pp.-227
} 
dissidents conducted abroad occurred during the period from 1945 to $1981 .^{169}$ Many of these dissidents were part of disillusioned ethnicities that resented continued presence in a unified Yugoslavia, while they were repressed by intelligence services that continued to be dominated by Serbs, some modest attempts at balancing the ethnic composition of the intelligence community occurred after $1966 .^{170}$ These ethnic realities would come to the surface during the dissolution of Yugoslavia and the ensuing wars, as the Serb dominated security services came under the control of the Serbian leadership and was used on the ground in Croatia, Bosnia and Herzegovina and Kosovo.

\section{The security and intelligence services under Milošević}

As Serbian President since 1989, Milošević had direct influence over the republic's interior forces, which he placed under closer control. Milošević based his power on the Serbian Ministry of the Interior, which was by far the largest in the SFRY. Following the secession of most of the republics, the SFRY was dissolved in 1992 and was replaced by the Federal Republic of Yugoslavia (FRY), a rump state that only included Serbia and Montenegro, while the JNA became the Yugoslave Army (VJ).

The MUP and the SDB underwent a number of organizational transformations that primarily aimed at centralizing their control in the hands of the Serbian president, serving as counterweights to the military organizations never fully trusted by Milošević. 171 As a component of the VJ, KOS was associated with the federal Yugoslav government, which ensured a distance from the republic's government and made KOS an

\footnotetext{
${ }^{169}$ Ibid, p.233

170 Ibid, p.234

171 ICG “Fighting To Control Yugoslavia's Military", Europe Briefing N²6, (15 July 2002), pp.18-19
} 
ally more than a subordinate of Milošević, at least until he became the Yugoslav president in $1997 .^{172}$

The 1991 Law of Internal Affairs created two branches for the MUP, namely the SDB and the Public Security Department. ${ }^{173}$ These two branches had separate, parallel structures throughout the country and the SDB tended to answer directly to the president, although it was nominally under the control of the Minister of the Interior. ${ }^{174}$ Even the SID, nominally a federal institution, came under increasing SDB control, reversing the independence that had been achieved following the fall of Ranković. ${ }^{175}$ During this time, the federal MUP was under de facto control by the Serbian MUP. ${ }^{176}$ While these measures ensured executive control over the security services, there was no legislative review of the SDB. During the communist period, there had been an SDB oversight committee that enforced functional control through one party rule, but it was not revived under the FRY after 1992. While there was an attempt to recentralize power federally when Milošević became FRY president in 1997, including attempts to create a federal SDB, these plans never went forward due to Montenegro's opposition. ${ }^{177}$ Although, the Serbian SDB continued to report directly to Milošević after he acceded to the federal presidency. ${ }^{178}$ These examples illustrate the limits of the law as back-door channels that concentrated power in the hands of Milošević constantly undermined the legal framework.

\footnotetext{
${ }^{172}$ T. Edmunds, "Intelligence Agencies and Democratisation: Continuity and Change in Serbia after Milosević" Europe-Asia Studies, vol.60, iss. 1, (January 2008), pp. 31-32

${ }_{173}$ Babovic, (34).

${ }^{174}$ Ibid, (57).

175 Intelligence Online "Le plan de destabilisation des Occidentaux", (8 April 1999).

${ }^{176}$ Babović, $(24,26)$.

${ }^{177}$ Ibid, (25).

$178 \underline{\text { Ibid, }}$ (82).
} 
The head of the SDB during most of this period was Jovica Stanišić, a loyalist that played an important role in supporting Milošević's rise to power. ${ }^{179}$ Stanišić was responsible for coordinating the Serbian security services and oversaw state support for paramilitary groups during the conflict until he was replaced by Radomir Marković in 1998. ${ }^{180}$ Interestingly enough, it has been revealed during Stanišić's subsequent trial by the ICTY that he had been in contact with the Central Intelligence Agency's Belgrade station chief since 1991, providing the Americans with information from inside the regime and even providing them with the plans of Yugoslav-built Iraqi bunkers in 1992. ${ }^{181}$ Stanišić was a pragmatist with strong ties to with Milošević, and as a result his counsel was often sought due to his daily access to the Serbian president. ${ }^{182}$ His position was solidified by his role as provider of information to Milošević. Indeed, as head of the SDB and a top member of the MUP, Stanišić was the gateway of information to Milošević, serving as an intermediary with Radovan Karadžić and keeping the Serbian president abreast of developments in the Bosnian-Serb leader's entourage. ${ }^{183}$ Interestingly, Stanišić played a dual role of both preparing Serbia for the wars of the Yugoslav succession and in cooling it down. He progressively lost his influence in the years following the Dayton Accords, coming to a head during the student protests of winter 1996-1997. ${ }^{184}$ Rade Marković, a member of Milošević's personal circle, ultimately replaced him.

${ }^{179}$ Le Point "Portrait; Jovica Stanišić le prétorien de Milošević", (3 May 1997).

${ }^{180}$ Edmunds Intelligence, p. 27

181 ANSA "Serbia Ex Capo 007 Milošević era uomo CIA a Belgrade", ANSA Notizario Generale in Italiano, (2 March 2009).

G. Miller. "Serbian spy's trial lifts cloak on his CIA alliance" The Los Angeles Times, (1 March 2009).

${ }_{182}$ I. Badurina. "Retroscena l'ombre del tribunal dell'Aie" La Stampa, (14 March 2003), p.9.

${ }^{183}$ Le Point, 3 May 1997.

${ }^{184}$ D. Anastasijavić (Vreme), "Jovica Stanisić, notre agent double à Belgrade", Courrier International, (23 April 2009), p.42 
During the course of the conflicts in Croatia and Bosnia and Herzegovina, a major source of funds for the Serbian security service and MUP was through the Federal Customs Administration that would transfer funds to Yugoslav and international banks, avoiding international sanctions. ${ }^{185}$ Supplementary income would be provided by parallel power structures which merged organized crime, security and law enforcement elements. The link between the security services and organized crime elements went back to the Cold War when during the 1970's, the Yugoslav security service began using criminals to carry out political assassinations abroad. In the 1990's, due to the crippling effects of international economic sanctions and the need to sustain Serb forces in BosniaHerzegovina $(\mathrm{BiH})$ and Croatia, the security services were used to engage in smuggling illicit goods ranging from petrol and cigarettes to drugs and arms. The profits were then used to fund and arm Serb forces, as well as handsomely reward those who took part in these dealings. ${ }^{186}$ In fact, a number of those engaging in the smuggling and paramilitary units had been recruited by the MUP in prisons. ${ }^{187}$ The close relationship between the security services and organized crime would leave a lasting legacy and have important consequences on later attempts to reform the security and intelligence services.

The prime example of the nexus between organized crime and the security services can be found in the creation of paramilitary units that fell under the supervision of the SDB and engaged in organized crime and war crimes. The Special Operations Unit (JSO) was created as an SDB special operations group under the command of Franko

\footnotetext{
${ }^{185}$ M. Torkildsen, “Amended Expert Report of Morten Torkildsen", Case No.IT-02-54-T, International Criminal Tribunal for the former-Yugoslavia, (7 June 2002), p. 7

${ }^{186}$ Center for the Study of Democracy (CSD), Partners in Crime: The risk of symbiosis between the Security Sector and organized crime in South East Europe, (2004), pp.42-43.

${ }^{187}$ ICG Fighting Control Military, p. 14
} 
"Frenki" Simatović, Jovica Stanišić's right-hand man. ${ }^{188}$ The JSO played a large role in organizing and coordinating militias that engaged in ethnic cleansing during the conflicts of 1991-1995 and 1998-1999. ${ }^{189}$ As a unit, it received better equipment, pay and training than the VJ. Its alliance with the Zemun Clan organized crime group permitted the creation of self-financing mechanisms for the SDB and the JSO that would continue to function until the dissolution of the unit. ${ }^{190}$ The end of the conflict in $\mathrm{BiH}$ and the partial lifting of international sanctions against Serbia marked the beginning of the end of the alliance between the security services and organized crime. A number of assassinations took place during this period that involved high-ranking officials, members of the security services and notorious criminals. ${ }^{191}$ At the end of its time in power, the Milošević regime had transformed itself into a regime deeply based in criminal activities, in which the organs of the state and organized crime were virtually synonymous.

\section{The 5 October democratic revolution}

Throughout the conflicts of the nineties, the Serbian population had for the most part followed the diktat from Belgrade under the leadership of Slobodan Milošević. During the 1991-1995 war, the opposition in Serbia had been silenced by the wave of Serbian nationalism which was encouraged by Milošević. The negotiations at Dayton helped establish Milošević as a rational interlocutor who was pursuing peace, a position that diminished the power of any opposition. ${ }^{192}$ As such, ironically, the breakthrough at

\footnotetext{
${ }^{188}$ Babović (165-166).

${ }^{189}$ Edmunds Intelligence, pp.32-33

${ }^{190}$ ICG “Serbia After Djindjic", Europe Report N¹41, (18 March 2003), p. 7

${ }^{191} \mathrm{CSD}, \mathrm{pp} .57-58$

192 O. Kesic, "An Airplane with Eighteen Pilots: Serbia After Milošević" in S.P. Ramet, \& V. Pvlakovic, editors. Serbia Since 1989: Politics and Society under Milošević and After. (Seattle: 2005), p. 99
} 
Dayton consolidated Milošević's power in Serbia, even in the face of defeat by Serb forces.

The spark that led to the events of 5 October 2000 was Milošević's decision to change the constitution in order to run for a second term as federal president. After stealing the victory from his opponent, the candidate for the Democratic Opposition of Serbia Vojislav Koštunica, public pressure began to rise as police refused to crack down on striking miners, leading to a first symbolic victory for the opposition on 4 October. ${ }^{193}$ Early on the morning of the 5 October, convoys of protestors began converging on Belgrade, pushing through police barricades which offered little resistance. These hordes of protesters, some of them following the lead of the D.O.S., many others just ordinary Serb citizens who were fed up with the Milošević regime, swarmed the streets of Belgrade, taking over strategic points such as the federal Parliament and one of the most despised organs of state propaganda, Radio-Television Serbia. ${ }^{194}$ While 5 October was a major triumph for democracy in Serbia, there were major constitutional challenges for Koštunica, who needed to reform many state institutions that were still permeated with elements of corruption which had thrived under Milošević's nepotism. This included the economy, of which it was stated that seventy percent of transactions took place in a gray area that was completely outside government control. ${ }^{195}$ Following the decision of the constitutional court to confirm that he had won the elections which had taken place earlier in September, Koštunica was confirmed as the new president of the FRY, with

\footnotetext{
${ }^{193}$ D. Bujosevic and I. Radovanovic, The Fall of Miosevic: The October $5^{\text {th }}$ Revolution (New York: 2003), pp. 16-23

${ }^{104}$ Bujosevic \& Radovanovic., pp.113-124

${ }^{195}$ M. Glenny, "The Revolution was the Easy Part", The New York Times (7 October 2000).
} 
Milošević resigning from his post. ${ }^{196}$ In one day, the Serbian population had managed to do what two months of bombing did not accomplish: removing Milošević from power.

\section{Conclusion}

As this chapter has demonstrated, the role of the security and intelligence services of Georgia and Serbia during the twentieth century was based primarily on protecting the regime. In addition to their straightforward role of repression, the security services also served an ideological purpose of promoting communism, socialism or, as during the Royal Dictatorship, Yugoslavism.

Under these conditions, the security services grew to disproportionate sizes, becoming states within states. The power of the heads of these services grew alongside the services, until there was little to no control of the state security apparatus by the regime itself. In both of these countries there was an ultimate adjustment of the balance of power with both Alexandar Ranković and Lavrentiy Beria being removed from power, the former sent into retirement and the latter executed. In both Yugoslavia and the Soviet Union, the security services were reigned in and submitted to increased scrutiny by their respective Communist Parties, limiting their autonomy and role to that of a political police. Organizationally, the military and its intelligence components came to play a larger role. In Yugoslavia, the military remained in a position of force until the republican SDB's ascent under Milošević, while in Georgia, the republican KGB remained under the control of a soldier until the mid-1980s, slowly rising to prominence during the chaos of the post-independence years.

${ }^{196}$ Bujosevic \& Radovanovic, pp. 173-175 
The end of Yugoslavia and the Soviet Union caused a resurgence of the security services in Serbia and Georgia, although to varying degrees. In Serbia, the existing republican forces were favoured as an instrument of the regime to counter the influence of the ideologically suspect JNA and as a means of fighting during the Wars of the Yugoslav Succession. In Georgia, the priority was the formation of a security sector to establish central control over the country and the first years were consumed by internal fighting between various militias and with secessionist regions. In both Serbia and Georgia, the security services are seen as important agents of nationalizing nation-states, and have helped to consolidate national states or nationalist programs. This is especially true in the case of Georgia, where the security sector was crucial in the formation of the central state throughout the chaos of civil war. The security services that emerged were steeped in a siege mentality and focused on the protection of the central authorities. Following a decade of post-communist authoritarian rule, popular discontent led to an overthrow of the regime that was allowed by the security and intelligence services. These revolutions brought forward the first condition for successful reform, the election of legitimate democratic governments. A priority of the new governments was to assert control through the difficult relationships between the political elite and the security and intelligence services. 


\section{Chapter III \\ Strange Bedfellows: Democratic institutions and intelligence services}

After their democratic revolutions, a priority of the new governments of Georgia and Serbia was to establish control and review of the security services that had been props of the previous regimes. As this chapter will illustrate, the process of security and intelligence reform has been challenging for various reasons in both countries. It has been remarked, "Serbia's new democratic elite had to cope with a far more complex set of challenges than their Central and Eastern European counterparts". ${ }^{197}$ This statement can be applied to the challenges that faced the new government in Georgia and this reality must be kept in mind while studying developments in the security and intelligence services.

The security sector exists to provide protection to the state and the people. In the liberal democratic state, the security and intelligence services are subordinate to the representatives of the people and must act within the constitution. In practical terms, this means that the security and intelligence services are accountable to the government and the legislature and must act within the framework of the law. The first level of analysis that will be examined is the political level. According to Edmunds, the political level of analysis primarily addresses the relationship between the security sector and the political process. ${ }^{198}$ This uneasy relationship is based on maintaining a fine balance between the democratic control of the security and intelligence services on the one hand, and the need

\footnotetext{
${ }^{197}$ F. Ejdus, "Democratic Security Sector Governance in Serbia", Peace Research Institute Frankfurt Reports, n.94, (2010), p.1

${ }^{198}$ Edmunds SSR Transforming, p.27
} 
for professional distance and avoiding the politicization of the services on the other. Unfortunately, as the present chapter will demonstrate, this balance has not always been maintained.

Through this examination of the political level, it will be demonstrated that the main challenges to the process of security and intelligence reform in Serbia and Georgia have been based on two main deficiencies. The deficiency that will be made most apparent is the lack of strong political will to reform the security sector by the political elites, both in and out of government. In addition, there was institutional continuity following the countries' respective revolutions where the legacies from the previous, more repressive eras, remained firmly entrenched.

The revolutions in Georgia and Serbia put into place governments that had the stated objective of reforming state institutions towards the liberal-democratic ideal. However, as is the case in every state, the ideal and the reality did not correspond exactly, as will be demonstrated in ensuing sections examining the political developments and implementation of democratic control over the security and intelligence services in Georgia and Serbia. This will be achieved by investigating the components of democratic control at the political level, such as the establishment of a legal framework for the operations of the services, executive control, legislative review, judiciary review and the engagement and participation of civil society. These elements are firmly rooted in the values of the liberal-democratic state and reflect a Western-orientated domain that promotes the rule of law and the implementation of checks and balances to centralized power. In his framework, Edmunds establishes the international level as a separate level 
of analysis for security sector reform. In contrast, this thesis will integrate the international level within the political level.

\section{A note on governance}

Before addressing the issue of democratically controlling the security intelligence apparatus, a note must be made on governance. A number of authors agree that good governance must first be established, based on the key principles of pluralism, transparency, equity, accountability, rule of law and respect for human rights, in order to ensure the effective control and review of security and intelligence agencies. ${ }^{199}$ Without the establishment of good governance, the result may be that the security services provide good accountability to bad government. This conclusion is echoed by Robert Larsson, who noted that while there was limited parliamentary oversight in Georgia during the $1990 \mathrm{~s}$, it was of limited use because of the institution's lack of integrity. ${ }^{200}$ Because of the sensitive nature of intelligence, there is a need to firmly establish the credibility of elected officials before they can provide proper review of these services. ${ }^{201}$ As such, security sector reform can only be effective if it is introduced in tandem with wider institutional reforms.

\section{The challenges of consolidating the gains of the revolutions:}

\section{Political developments in Georgia and Serbia}

As was so often the case before and since, the revolutions in Georgia and Serbia were to prove the easiest part of their political transition. From the first day, the new governments were confronted by the challenges of governing their countries. The

\footnotetext{
${ }^{199}$ Born \& Leigh, pp.21-22; Martin, p.561

${ }^{200}$ Larsson, p. 25

${ }^{201}$ Watts, p. 17
} 
revolutions had been a success in part because the security and intelligence services had stood aside to let the regimes collapse. Now, the new governments had to establish their control over the security sector as one of the main priorities, while facing numerous other challenges.

\section{From Shevardnadze to Saakashvili: Georgia since 2003}

Following Shevardnadze's resignation in November 2003 and the successful election of Saakashivili to the Georgian presidency in early 2004, the opposition inherited government institutions that, while imperfect, were functional and retained a monopoly on legitimate violence over a majority of the territory of Georgia. However, the security sector had been discredited in the eyes of the public as corrupt supporters of the Shevardnadze regime. This negative perception was centered on the regular police forces, notably the highway police, who abused their position to extract bribes from citizens. Shortly after gaining power, the Saakashvili government simply disbanded the highway police, an example of the government's willingness to distinguish itself from the previous regime, even if this was to be done recklessly.

There has been overall progress in the general reform attempts of the Georgian state since 2004, although this has occurred in parallel with authoritarian tendencies. While a number of modernization and liberalization of the economy efforts have succeeded, political power has been concentrated in the hands of the president which dominates parliament. Areas that have seen progress include the improving conditions for minority groups and successful efforts against torture and for the humane treatment of prisoners. From the beginning, a number of other sectors were targeted as needing reform, such as the civil service, and there was an emphasis on the protection of property 
rights. ${ }^{202}$ In addition, the new government did not have control over the secessionist regions of Abkhazia and South Ossetia and only nominal control over Adjara. While Adjara was successfully reintegrated, a number of armed skirmishes occurred in South Ossetia that nearly led to war during the summer of $2004 .{ }^{203}$ The secessionist regions remained a major threat to Georgia and a sore point in the country's relations with Russia. Tensions with Russia grew increasingly; in fall 2006, four Russian servicemen were arrested by Georgian security forces. Their arrest was widely publicized by the Georgians, who eventually handed them over to Russia. In retaliation, Moscow imposed economic sanctions on Tbilisi and the mass deportation of Georgians living in Russia. ${ }^{204}$ The war of words between the two countries would continue, with new "spies" being regularly discovered on both sides of the border.

The centralization of power in the hands of the president and few checks and balances provide an additional cause for concern. This culminated in November 2007 when thousands of protestors took to the streets of Tbilisi, calling for Saakashvili's resignation. In response, the government declared a state of emergency and the protestors were brutally dispersed, while some independent television stations, which had taken a stance against the government, were shut down. ${ }^{205}$ The government claimed that the opposition was being directed by Moscow, rhetoric that had been escalating since the 2006 spy scandal between the two countries.

\footnotetext{
${ }^{202}$ Commission of the European Communities, European Union / Georgia Action Plan, (2004), pp.3-5

${ }^{20.3}$ Independent International Fact-Finding Mission on the Conflict in Georgia (IIFFMCG), Report:

Volume II (September 2009), pp. 12-17

${ }^{204}$ IIFFMCG, pp. 17-22.

${ }^{205}$ International Crisis Group (ICG), Georgia: Sliding Towards Authoritarianism?, (19 December 2007), pp. $2-5$
} 
The eruption of conflict in August 2008 between Russia and Georgia was the climax of a continuous deterioration in relations between the two states. For Moscow, the Caucasus is an area that falls squarely within its traditional sphere of influence, having been for nearly two hundred years a part of the Russian Empire and of the Soviet Union. Under the presidency of Vladimir Putin, the Kremlin continually attempted to increase its influence in Georgia, using the secessionist regions as leverage to coerce the Georgian government. ${ }^{206}$ This has increased since the Rose Revolution which, along with the 2004 Orange Revolution in Ukraine and the 2005 Tulip Revolution in Kyrgyzstan, confirmed the perception in the Kremlin of Western encirclement. ${ }^{207}$ The main issue in Georgia's relations with Russia was Tbilisi's drive for NATO membership, a possibility which remains unacceptable for Moscow as it would continue the perceived Western encirclement of Russia. As a result, Russia has increased its influence in Georgia's secessionist regions in an effort to use them as leverage to coerce Tbilisi to halt its EuroAtlantic ambitions.

Kosovo's declaration of independence on 17 February and the subsequent recognition of the new state by many Western states served as a watershed moment in the relations between the two countries. Following Kosovo's declaration of independence, which Moscow strongly opposed, Russia increased its support to Abkhazia and South Ossetia through legal, diplomatic and military means. In Abkhazia in particular, there have been calls by local nationalists for self-governance, as they believe they have the necessary institutions for self-governance without international protection, which they

\footnotetext{
${ }^{206}$ ICG, Georgia: What Now? (3 December 2003), p.4

${ }^{207}$ ICG, Georgia Authoritarianism, p.9
} 
claim was not the case in Kosovo. ${ }^{208}$ There were a number of military incidents in spring 2008. Most notably on 18 March, and then again on 20 April, Abkhaz authorities claimed to have shot down an unmanned aerial drone. The first claim was denied by the Georgian government whereas the second claim was reluctantly acknowledged by Tbilisi, which stated that the drone had been shot down by a Russian aircraft. ${ }^{209}$ These air incursions had occurred several times during the decade, with the International Independent International Fact-Finding Mission on the Conflict in Georgia (IFFMCG) estimating that this occurred at least five times. ${ }^{210}$ In parallel to these developments, Russia had announced an increase in the number of soldiers in Abkhazia and that it would enhance its ties with the secessionist regions.

The trigger for the conflict was provided by the Georgian military on 8 August 2008. Early that morning, Georgian military forces launched an offensive on Tskhinvali, claiming to be responding to shelling from South Ossetian positions as well as perceived Russian troop movements. Thirty minutes later, columns of Russian armoured vehicles entered South Ossetia from the Roki Tunnel, which links the Russian Federation to South Ossetia. ${ }^{211}$ This counter attack by the Russian military took the Georgian forces by surprise; the Georgian authorities believed that Russia did not pose a military threat and would not intervene. ${ }^{212}$ This decision was based partly on faulty intelligence and had dire consequences for the Georgians. After a few days of conflict that saw Russian troops

\footnotetext{
${ }^{208}$ ICG, Georgia and Russia: Clashing Over Abkhazia, (5 June 2008), pp.15-16

${ }^{209}$ ICG Georgia and Russia, pp.3-4

${ }^{210}$ IIFFMCG, p.24

${ }^{211}$ ICG, Georgia vs. Russia: The Fallout, (22 August 2008), p.1

${ }^{212}$ M. Hancock \& M. Varvitsiotis, European Security After the War in Georgia: Report to the Western European Union Assembly. Document A/2029, (4 December 2008), p.7
} 
invade Georgia proper and threaten Tbilisi, French president Nicholas Sarkozy sponsored a cease-fire agreement between Russia and Georgia, which ended the war.

The end of the war did not signify the end of tensions between the two countries. Since then, a number of new spy scandals have erupted. In late October 2010, members of the Ministry of Internal Affairs' Counter-Intelligence Department (CID) arrested a number of suspected spies in a widely publicized operation, video footage of which was subsequently posted on the Interior Ministry's website. While Russia denied claims of espionage as Tbilisi's latest fabrication, Georgia claimed that it had infiltrated Russian military intelligence in order to capture the alleged spies. ${ }^{213}$ This advertisement of a successful counter-intelligence operation is a recurring theme in the operations of the Georgian security and intelligence services. While they serve to highlight alleged successes by the intelligence community, the mass publication of spy scandals also serve to constantly depict Russia as the enemy and anyone who may be in contact with Moscow as a traitor.

While the opposition rallied behind the president along with the rest of the country, there has been increasing questioning since 2008 of the government's actions in the lead up to the conflict. Most recently, during May 2011 protests which lasted five days and resulted in two deaths, the government accused the opposition of collusion with Russia; the Ministry of the Interior released videotapes showing opposition figures meeting with Russian officials. The president claimed that the protesters were following Russian orders to disrupt the military parade that was planned for $26 \mathrm{May} .{ }^{214}$ This

\footnotetext{
${ }^{213}$ M. Antidze "Georgia says breaks up Russian spy network", Reuters (5 November 2010), http://af.reuters.com/article/worldNews/idAFTRE6A41FG20101105? sp=true

${ }^{214}$ Civil Georgia, "Saakashvili: Recent Protest's Scenario Written in Russia", (26 May 2011), http://www.civil.ge/eng/article.php?id=23530
} 
recurring theme places the operations of the security services in a politically delicate position with the government, depicting the opposition as threats to national security. This was the latest example of the political elite instrumentalizing the security sector for political ends. The use of Ministry of the Interior resources to demonize the opposition was especially worrying, as it brought the security and intelligence services squarely within the political field.

\section{Serbia hesitating between extra- and intro-version}

Following the success of the 5 October revolution, reinforced by the Serbian legislative electoral victory of December 2000, the DOS formed the new government at both the federal and republican levels. However, old divisions quickly surfaced between the various political parties that formed the DOS coalition, fractured along the two levels of government. New power structures emerged around federal president Koštunica and Serbian premier Zoran Đinđić, as each consolidated their power base and control over the security services that answered to their respective governments. ${ }^{215}$

The Serbian government was led by a coalition under Đinđić's Democratic Party (DS). As Serbian Premier, Đindić had legal control over the SDB and the JSO. However, in the initial months of the new government, the status quo remained. Notably, although he had been the main enforcer of the Milošević regime, Radomir Marković was only dismissed as head of the SDB on 26 January 2001 ; he was subsequently arrested and investigated for the disappearance of former Serbian president Ivan Stambolic and the assassination attempt on opposition leader Vuk Drašković in $2000 .{ }^{216}$ This four month period gave the SDB head plenty of time to dispose of any incriminating internal files.

\footnotetext{
${ }^{215}$ ICG, Serbia: Military Intervention Threatens Democratic Reform, (28 March 2002)., pp.14-15

${ }^{216}$ ICG, Serbia's Transition: Reforms Under Siege, (21 September 2001). p. 9
} 
The nexus between organized crime and the security services resurfaced in the tensions between the two heads of government, as was illustrated by the Gavrilović affair. On 3 August 2001, Momir Gavrilović, a former member of the SDB, was assassinated a few hours after meeting with members of the Yugoslav presidential administration. Following a leak to the press by a member of the presidential administration, there were claims that Gavrilović had alleged strong links between the Surčin Clan, an organized crime group, and the Serbian government. Accusations and counter-accusations were publicly made between associates of Koštunica and of Đinđić, until the public prosecutor officially requested evidence from the presidential administration. It soon became apparent that there was little evidence of collaboration between the republican government and elements of organized crime. ${ }^{217}$ This event highlighted the continual superimposition of organized crime, the security services and acrimonious relations between Koštunica and Đinđić.

Throughout the post-Milošević era, relations with the ICTY remained a constant cause of disagreement between the international community and Serbia, as well as within the Serbian political class itself. The summer 2001 arrest of Slobodan Milošević by members of the JSO accentuated the abyss between Koštunica and Đinđici. ${ }^{218}$ In addition, it contributed to growing tensions between the Serbian government and the JSO, leading to the unit going on strike in November 2001 when they blocked a major Belgrade highway. During this event, Koštunica publicly supported the strikers, accentuating the perception that the Serbian government was not in control its own security forces. ${ }^{219}$ The JSO was subsequently placed under the direct control of the Interior Ministry; the

\footnotetext{
${ }^{217}$ Ibid, pp. 1-3

218 G. Pörzen, "Nach dem Mord an Zoran Djindjic", Südosteuropa Mitteilungen, (02/2003), p.30.

${ }^{219}$ ICG, Military Intervention, p.19
} 
creation of this formal line of command ostensibly added further executive control over the services, but did not involve more legislative accountability.

In addition to these changes to the JSO, there were changes in the security service. In 2002, the SDB was abolished and replaced by the Security Information Agency (Bezbednosno-informativna agencija, or BIA), an independent organization responsible directly to the Prime Minister. However, even with these changes the organizational culture remained similar to that of the SDB, as will be discussed in subsequent sections. ${ }^{220}$ In the short term, the catalyst for reform of the security sector would come with the assassination of Đinđić in March 2003.

On 12 March 2003, Serbian Prime Minister Zoran Đinđić was assassinated by a sniper outside the offices of the Serbian government. From December 2002 onwards, Dinđić adopted tougher measures against organized crime and accentuated cooperation with the ICTY. This more aggressive position came from the shift in the political balance of power from Koštunica to Đinđić, with the Serbian Prime Minister increasing his influence within the governmental apparatus, as the very position of Yugoslav President was soon to be abolished with the dissolution of the FRY and the creation of the confederal State Union of Serbia and Montenegro. ${ }^{221}$ Although he was not beloved by the Serbian public, his assassination propelled Đinđić into the status of national hero, at least in the progressive segments of the population.

The Serbian government declared a state of emergency in the hours following the murder of Đindić. It has been argued that Serbia's institutions were not strong enough to sustain the impact of the assassination without the ensuing state of emergency and

\footnotetext{
${ }^{220}$ ICG, Serbian Reform Stalls Again, (17 July 2003), p.16

${ }^{221}$ Pörzgen, p.31
} 
crackdown on organized crime. ${ }^{222}$ Members of the JSO were quickly named as responsible, with Milorad Luković becoming the prime suspect. In the days following the declaration of the state of emergency there was a crackdown against the Zemun Clan that targeted, aside from suspects in the assassination, those responsible for the disappearance of Ivan Stambolić, the assassination attempt on Vuk Draškoviç and fifty other unsolved murders that had occurred between 1999 and 2003. Because of their close ties to the JSO and the Zemun Clan, former SDB leaders Jovica Stanišić and Franko Simatović were arrested during Operation Sabre before being indicted and transferred to The Hague. ${ }^{223}$ As a result of its role in the assassination, the JSO was disbanded while untainted members of the unit were transferred to other police units. ${ }^{224}$ The dissolution of the paramilitary group, which had little to no accountability, was a major step towards establishing democratic control of the security services.

It must be noted that there were numerous problems during Operation Sabre. For one, a number of bystanders were caught up in the police net and publicly accused before being released without charges. ${ }^{225}$ During the course of the operation a number of media outlets were closed, even if they were not associated with the Zemun Clan but simply opposed government policies. ${ }^{226}$ While there were allegations that the police used torture against detainees, these were dismissed following inspections by the delegations of the Organization for Security and Cooperation (OSCE) and the Council of Europe. ${ }^{227}$ The rapidity and effectiveness of the operation underline the fact that when there is political

\footnotetext{
${ }^{222}$ Helsinki Committee for Human Rights in Serbia (HCHRS), Human Rights and Accountability: Serbia 2003, (2004), p.87

${ }^{223}$ ICG, Serbia After Djindjic, (18 March 2003), p. 2

${ }^{224}$ CSD, p.64

${ }^{225}$ ICG, Reform Stalls, pp. 1-2

${ }^{226}$ Ibid, p.9

${ }^{227}$ HCHRS Serbia 2003, pp. 177-178
} 
will, efficient police action is possible. This speed would also suggest that the police and security services were aware of significant information about a number of unsolved crimes that were not pursued until Sabre, which highlights the continued existence of power structures that were not accountable to the government. ${ }^{228}$ Later that year, however, the Democratic Party-led coalition government was defeated in legislative elections.

Having moved from Yugoslav to Serbian republican politics, Koštunica of the Democratic Party of Serbia (DSS) was elected to the position of Prime Minister in December 2003. His government has been described as nationalist-conservative, emphasizing national independence and limiting reform efforts. ${ }^{229}$ Under the new administration, there lacked the political will to seriously pursue the prosecution and investigation of organized crime that had started in $2003 .{ }^{230}$ These trends were confirmed during the government's subsequent years in power. This stagnation had a direct impact on the security and intelligence services, which limited cooperation with the ICTY to the point where EU officials stated that they would not countenance integration talks with Serbia until the DS was responsible for the security ministries. ${ }^{231}$ Indeed, it is interesting to note that the capture of Karadžić and the remaining fugitives occurred only after the DS won the 2008 legislative elections.

The establishment of an independent Serbian state created the proper occasion to revamp the country's legal framework and its security sector. Following Montenegro's secession, Serbia inherited the intelligence and security services of the federal

\footnotetext{
${ }^{228}$ ICG, Reform Stalls, p.14

${ }^{229}$ ICG Serbia's U-Turn, p.7

${ }^{230}$ HCHRS Human Rights and Collective Identity: Serbia 2004, (2005), pp.120-121

${ }^{231}$ ICG Serbia's New Government, p.5
} 
government. The introduction of the Serbian constitution in 2006, following a popular referendum, created a number of basic legal rights for citizens, forming a wider legal framework in which the services must operate. As will be further discussed subsequently, the legal framework was updated for a number of smaller agencies, namely military intelligence, as well as the dissolution of the foreign office's SID as a separate intelligence agency. However, BIA continued to operate in accordance with the 2002 laws passed under the FRY. ${ }^{232}$ The law governing BIA has yet to be updated.

Since 2008, the importance of reforming the security and intelligence services has been heightened by a number of international factors, such as increased cooperation with the EU and the drive to arrest fugitive Bosnian Serb commander Ratko Mladić. ${ }^{233}$ The arrest of former Bosnian Serb leader Karadžić in July 2008 was a major coup for the Serbian security and intelligence services. While relations between the ICTY and the Serbian authorities improved, there was continued concern over the limited progress in the hunt for Mladić. On 26 May 2011, Serbian President Boris Tadić announced Mladić's arrest by the security forces. It was announced that the fugitive had been living under the pseudonym 'Milorad Komadić', had surrendered without resisting arrest and was now in the custody of the BIA. ${ }^{234}$ The arrest was hailed in the majority of Western capitals, which noted that Mladić's capture marked a good day for both Serbia and BosniaHerzegovina. ${ }^{235}$ The arrest of Mladić and Karadžić highlights the importance of strong

\footnotetext{
${ }^{23.1}$ HCHRS, Self Isolation: Reality and the Goal - Helsinki Committee's Annual Report for 2007, (2008), pp. $189-190$

${ }^{233}$ HCHRS, Human Rights - Hostage to the State's Regression - Helsinki Committee's Annual Report for 2006, (2007), pp.210-211.

${ }^{234}$ La Repubblica, "Arrestato Ratko Mladic "Il boia" di Srebrenica" (26 May 2011), hitp://www.repubblica.it/esteri/2011/05/26/news/mladic arresto-16775314/

${ }^{235}$ M. Martens, "Ein gutter Tag für Serbien", Frankfurter Allgemeine Zeitung, (26 May 2011) http:/www.faz.net/artikel/C30089/kommentar-ein-guter-tag-fuer-serbien-30376391.html
} 
political will both in bringing to justice indicted war criminals and in the process of security and intelligence reform overall.

\section{Conclusion}

Georgia and Serbia have had numerous challenges to their political transitions, both internal and external. In Georgia, the government quickly established its dominance over government institutions and parliament but had to contend with major threats to its security, which along with poor leadership led to the 2008 war with Russia. These tensions with Moscow have often been used as a fig leaf by the Saakashvili government to crack down and marginalize opposition figures. This political climate is conducive to the politicization of the security and intelligence services and their use to deter the political opposition. On the other hand, Serbia has experienced a number of political changes as the country alternated between progressive governments, which had pushed for unpopular reforms and cooperation with the ICTY, and conservative nationalist governments, which emphasized the importance for Serbia in finding its own way. The period from 2000 to 2003 was overshadowed by tensions between Koštunica and Đindić and tentative reforms, while 2003 to 2006 marked political stagnation in the realm of security sector reform. Reform efforts intensified from 2006 onwards, with a clear emphasis on European integration especially after the 2008 elections. This lack of political consensus on the direction of the state is partly responsible for the haphazard reform efforts that have taken place. These wider political developments in both states would deeply influence the process of intelligence reform. As the subsequent sections will illustrate, these political realities impact executive control, legislative and judicial 
review efforts as the country's political realities and culture permeate the various institutions.

\section{Controlling the spies:}

\section{The establishment of executive control over the security and intelligence services}

Following the Bulldozer and Rose revolutions, the priority of the new governments in Georgia and Serbia was establishing control over the security sector, from the military to the police forces. Indeed, the establishment of executive control over the security sector is usually the first item in the reform process. By appointing the leadership, issuing directives and orders, and determining the budget of the services, the government is the main external actor that can control the activities of the security and intelligence services.

The government is the main consumer of intelligence and is responsible for setting the mandate and mission of the intelligence community. ${ }^{236}$ Indeed, the legal framework for the security and intelligence community is usually developed by the government before being submitted to the legislature for approval. In addition to laws, executive directions can establish the specific organization and mission of the intelligence services and while laws must be publicly available, that is not necessarily the case for decrees; they must conform to the law even if they are secret. ${ }^{237}$ This combination of public and secret orders, while not ideal, can provide one solution to balancing the need for accountability and operational secrecy.

\footnotetext{
${ }^{236}$ Bruneau \& Boraz, pp.12-13

${ }^{237}$ A. Wills. Understanding Intelligence Oversight (Geneva: 2010), p.9; DCAF 2006, pp.13-14 
The establishment of proper executive control over the security intelligence services is a fine art. While the services must be responsible to the government, they must remain politically neutral and conduct their business in the interests of the state and not of the government. Executive control is essential for legislative oversight, for if the security services are not responsible to the executive then they will likely not be accountable to the legislature. ${ }^{238}$ One key element in establishing executive control over these services is to place them under the control of a particular minister, thus ensuring ministerial responsibility. The role of the minister ought to be clearly defined with a number of safeguards adopted against any potential ministerial abuse, such as requiring that all orders be in writing, a copy of which would be sent to legislative or other reviewing authorities, as well as a right of direct access to the head of government for security and intelligence service heads. ${ }^{239}$ Simultaneously, the political neutrality of the services remains of prime importance in ensuring their effectiveness and credibility.

Finally, to support and implement proper executive control over the security and intelligence sectors, there is a need for an adequate bureaucratic capacity to exercise control with a distinct civilian expertise in security matters. ${ }^{240}$ Civilian expertise on security and intelligence issues will ensure that the government has access to independent advice and expertise on these questions. Otherwise, the government has limited ability to control and to direct the security and intelligence services, tending to refer decisions to the discretion of the professionals. In addition to its role with the executive, the development of civilian expertise in security issues will contribute to strengthening legislative review, as well as academic study and research in civil society. Through these

\footnotetext{
${ }^{238}$ Hannah et al., p. 12

${ }^{239}$ Born \& Leigh, pp.68-70

${ }^{240}$ Edmunds, SSR Concepts, p. 18
} 
mechanisms, and with proper institutional strength, the executive sets the direction of the security and intelligence services. Additionally, the government must ensure that the security sector acts within the established legal framework and is not used as a tool against the political opposition.

\section{Presidential dominance - Executive control in Georgia}

Since the Rose Revolution there have been few challenges in Georgia with regard to the establishment of executive control over the security sector. As the previous section has noted, large elements of the security sector had sided with the opposition forces during the popular uprising. This ensured that there was some loyalty to the new government even before it was officially elected in early 2004. Under the new government, the central figure remained the president, to whom ministers were held accountable. Even though the position of Prime Minister was created under the 2004 constitutional amendments, presidential powers were strengthened. ${ }^{241}$ This was partly reversed by constitutional amendments passed in 2010 which strengthened the powers of the Prime Minister. With Saakashvili's term expiring in 2013, many have seen in this a hint that he may run for the position of Prime Minister.

Once elected, the Saakashvili administration maintained the existing structures and institutions that controlled and coordinated the security sector. Most importantly, the National Security Council (NSC) was retained as the central organ for the control and coordination of the security and intelligence services. This was of the utmost importance as it was through the NSC, which brings together ministers, department heads and

\footnotetext{
${ }^{241}$ T. Akubardia, "Overview of the Legislation Facilitating the Civil Democratic Oversight of Armed Forces of Georgia", in T. Pataraia, editor, Democratic Control over the Georgian Armed Forces since the August 2008 War, (2010), p.20
} 
members of the presidential administration's security team, that the government sets the direction for national-security programs. The NSC has its own framework that grants it the authority to determine and implement policy. Through these organs, the president sets the direction for the intelligence services, with their activities limited theoretically only by the legal framework controlling them. ${ }^{242}$ Indeed, throughout their existence, the legal framework for the security and intelligence services has subordinated them and limited their accountability to the president, not to the government or to the parliament. This remains the case in the legal framework of the recently reconfigured Georgian Intelligence Service, which incorporates elements of security and foreign intelligence, as it reports and is accountable only to the president. ${ }^{243}$

This centralization of power in the hands of the government and especially the president has succeeded in establishing firm executive control over the security and intelligence services. However, this can lead to the politicization of the security and intelligence services if they are used to monitor opposition activities. Indeed, following the 2006 spy scandal, the government often accused the opposition forces of being directed by Moscow, claiming that the opposition is a threat to the state. ${ }^{244}$ Allegations were made by the Ministry of the Interior that opposition figures were meeting with Russian intelligence officials, the veracity of which has been questioned. ${ }^{245}$ This has been an ongoing trend and elicits worries that the government increasingly uses the security services for political purposes.

\footnotetext{
242 "The Law of Georgia: On Intelligence Activity" (Article 3) in P.Fluri, editor, Security Sector Laws of Georgia, (2005).

${ }^{243}$ Georgian Intelligence Service Law on Georgia Intelligence Service, $(2,9)$. http://www.gis.gov.ge/docs/Dazvervis_Samsaxuris Shesaxeb.pdf

${ }^{244}$ IIFMGC, pp.22-23

${ }^{245}$ IIFMGC, p. 23
} 


\section{Leashing the dogs of war - Executive control in Serbia}

Government control over the activities of the security and intelligence services has gradually been implemented in Serbia over the past decade. While the new government in Georgia could count on the loyalty of these institutions when they came into power, this was not the case in Serbia.

The non-intervention of the security forces and the army proved critical to the success of the Bulldozer Revolution. According to Edmunds, the negotiations which took place between the opposition and key players in the security apparatus were done with the intention of keeping the security sector, in particular the JSO under Legija, from intervening to save the regime and in the interests of "keeping them out of domestic politics and under civilian control." Future divisions could be foreseen in the fact that Koštunica negotiated with the VJ and Đinđić with the JSO ${ }^{246}$ However, this deal came at a high cost for the incoming government; in exchange for standing down on 5 October, the JSO was to be left intact. This also limited the influence of the new government over large sections of the security sector. As an example of this quid pro quo, the head of the Milošević era SDB was only removed from his position three months after the revolution, even though he was closely linked to organized crime and political assassinations that were endemic during the last years of the Milošević regime. This left him with enough time in office to ensure the destruction of any incriminating documents. ${ }^{247}$ Simultaneously, the commander of the Yugoslav military was not dismissed in the early months of the new government. It has been suggested that one potential reason why these two men remained in place was because of the unstable political situation in southern

\footnotetext{
${ }^{246}$ Edmunds, SSR Transforming, p.90-91

${ }^{247}$ Edmunds, SSR Transforming, p.91-92
} 
Serbia. ${ }^{248}$ In addition to letting them cover their tracks, this ensured that there was an inadequate reform at executive levels.

The divisions between the Serbian and Yugoslav governments, headed by Đinđić and Koštunica, respectively, undermined efforts at establishing effective government control. As a result, tensions quickly arose between the Serbian government and the security services. In November 2001, the JSO protested against government policy, blocking a key highway in Belgrade. During this time, the strikers had the support of Yugoslav president Koštunica, which undermined Đinđić's position. Following negotiations between the Serbian Prime Minister and the leadership of the JSO, the government conceded to dismissing the head of the SDB that was close to them, while the JSO was subordinated to the MUP. ${ }^{249}$ These concessions further weakened the power of the Serbian government over the security and intelligence services, while divisions within the Yugoslav government sent mixed messages and ensured that the security sector remained divided, dependent on the political masters to whom they reported.

The largest blow to executive control came with the assassination of Đinđic by members of the JSO in early 2003 . The assassination placed the spotlight squarely on the nexus between organized crime and the security services. Đinđić was planning a crackdown on organized crime and its presence in the security sector before he was assassinated. ${ }^{250}$ The shock caused by his assassination prompted the government to launch a widespread police operation aimed at fighting organized crime. It has been argued that Đinđić's assassination was but the first step in a coup attempt, but the shock

\footnotetext{
${ }^{248}$ Ejdus, p.9

${ }^{249}$ Edmunds, SSR Transforming, p.94

${ }^{250} \mathrm{G}$. Zaccaria,. "In Serbia la battaglia per la democratia e'ancora lontana dalla conclusione", La Stampa, 14 March 2003.
} 
of the assassination triggered a strong response from the government and a purge of state institutions. ${ }^{251}$ While this operation did not only have positive aspects, it did confirm executive control over the security sector.

In the year that followed Operation Sabre, Koštunica was elected to the premiership of Serbia and the reform process slowed down. The new administration did not prioritize the prosecution of organized crime or continued security sector reform. ${ }^{252}$ These trends were confirmed during the government's subsequent years in power. After becoming Prime Minister, Koštunica named one of his loyalists, Rade Bulatović, as director of BIA. It has been stated that the agency used as a political tool under this government, diverting international assistance funds to keep tabs on the political opposition. ${ }^{253}$ Situations reporting the politicization of the security and intelligence services have diminished since 2006, year that saw the introduction of the Serbian Constitution and the election of Boris Tadic to the presidency. With the new constitution naming the President chief of the armed forces, control for the security sector falls under the control of the President and the National Security Council. In parallel to these developments, there has been increased political continuity since the 2006 election, increased political control over the security and intelligence services. This reality has been reinforced since by the 2008 electoral victory of the DS that has seen the progressive 'For a European Serbia' coalition in control of government ministries.

${ }^{251}$ Intelligence Online "Le coup d'État manqué de Serbie", (4 April 2003).

${ }^{252}$ HCHRS Serbia 2004, pp.120-121

${ }^{253}$ Intelligence Online, "Retour aux bonnes vielles méthodes; Belgrade" (4 October 2007). 


\section{Conclusion}

Establishing control over the security sector is a priority for any new government taking over from a previous authoritarian regime. The challenges facing the incoming governments in Georgia and Serbia were similar, and yet there were differences. In both cases, the popular uprisings owed their success partly to the neutrality of the security services. While this did not create major issues in Georgia, where the government proceeded to transform large sections of the security and intelligence apparatus, this was not so in Serbia where the security services were left relatively undisturbed. There has been a tendency to appoint political loyalists to the direction of security and intelligence services in both of these countries, depending on the government in place. This is especially true in Georgia, where the security services are often used to depict the opposition as treasonable. Despite these concerns, both countries have been successful in establishing executive control over the security and intelligence services.

\section{Enshrining intelligence in law}

One of the central tenets of the liberal-democratic state is the rule of law. As such, one of the main principles of democratic control of the intelligence and security services is the establishment of a clear mandate and legal framework for the activities of these services. Hans Born and Ian Leigh make the argument that in a democracy, in order for any government agency to be legitimate, it must be based on the rule of law and have its mandate set on a legal framework. ${ }^{254}$ A strongly implemented legislative framework can enhance public trust and legitimacy for the state and its institutions.

\footnotetext{
${ }^{254}$ Born \& Leigh 2005, p.17
} 
There is a consensus in the literature regarding what should be included in any legislation on the security and intelligence services. There are different legislative options for how to set the mandate of the security services, whether it is present in the constitution, in a law, or through a government decree. Whichever option is selected, it must be clear, explicit and public, as much as possible. ${ }^{255} \mathrm{~A}$ legal framework ought to provide for the role and mission of the intelligence services, as well as their prerogatives and limits in accomplishing this role. In addition, it must provide a structure for review, list the roles and powers of controlling institutions, and provide a basis for accountability. ${ }^{256}$ By clearly stating these elements, a law on intelligence provides the basis for accountability and transparency in the security services. It is argued that in a more normative sense, a proper legal framework can instil new democratic values and a professional culture enshrined in the respect for the rule of law. ${ }^{257}$ Embedding the mandate and role of security intelligence within a legal framework provides a clear basis for the efficiency and accountability of the security and intelligence services.

One of the most important elements of any legal framework for intelligence activities is the establishment of a clear mandate for the security intelligence services that includes a nationally owned vision of security, which permits the services to adapt from their previous mission. ${ }^{258}$ The more precise the mandate, the more easily democratic control can be achieved, whereas broad mandates make it more difficult to precisely review the actions of the services.

\footnotetext{
${ }^{255}$ J. Lundum, J. Said Pullicino and A. Suirante, "Les Services de Sécurité Intérieur en Europe" Commission Européene pour la Démocratie par le Droit, (7 March 1998), pp.5-6

${ }^{256}$ Wills, p. 3

${ }^{257}$ Hannah et al. 2005, p.10

${ }^{258}$ Hannah et al., p.8
} 
When it comes to security intelligence, there is an ongoing debate in the literature over the law enforcement responsibilities that may be given to the security intelligence services. It has been noted that most often tradition will dictate whether security services are to be independent of or within the general police services, but that in both cases there needs to be a clear structure and accountability mechanisms. ${ }^{259}$ For example, in the United Kingdom, Germany, Canada and many Commonwealth states, the security intelligence services provide security intelligence to the relevant police departments to carry out arrests and accusations. On the other hand, in the United States and France, the security intelligence services are either integrated within the federal police force or have powers to arrest. Born and Leigh state that there needs to be a distinction between security intelligence and law enforcement, even though this approach can prove more difficult when dealing with issues such as organized crime. ${ }^{260}$ This view is echoed implicitly in a follow-up 2007 report by the Venice Commission which suggested that security intelligence services ought to focus on developing stronger analytical capacities, a view that is also supported by Wills. ${ }^{261}$ In the cases of Georgia and Serbia, security intelligence services have law enforcement powers. The most important consideration is not be whether these services should possess such powers, but whether there is appropriate control and accountability for them in light of this role.

Finally, any legal framework for security and intelligence services needs to ensure that the rights of citizens cannot be suspended on a whim. It is agreed that intelligence services ought not to begin surveillance on citizens who are acting lawfully, on legitimate

\footnotetext{
${ }^{259}$ Lundum et al., p.5

${ }^{260}$ Born \& Leigh, p. 29

${ }^{261}$ Lundum et al., pp.21-22; Wills, p.28
} 
opposition groups, or to further their own interest at the expense of the common good. ${ }^{262}$ Indeed, any spillover by the security services into the public sphere will betray a great deal of politicization of the security service and completely undermine both the reform process and the public's trust in the service's new role as protector of the state. The special powers of the security services are framed by the legislation which defines against whom or what and for how long surveillance methods can be applied. ${ }^{263}$ This is instituted in the hope that governments will not use the security intelligence services to support a given regime, as had been the case during authoritarian and early transition periods.

The establishment of a legal framework for the activities of the security and intelligence services enshrines them within the law. In addition, it increases accountability by demarking what the services may and may not do. Of course, to be successful, the legal framework must be implemented and adequate review must ensure that it remains in effect.

\section{The Georgian legal framework}

From that the moment the Shevardnadze administration began to shift Georgia's strategic orientation towards Euro-Atlantic integration, a number of legal documents were developed as part of early security sector reform efforts. A majority of the original laws on the security and intelligence services were passed during the Shevardnadze era and were actualized following the Rose Revolution.

The original legal framework developed under the Shevardnadze administration took into account the presence of several overlapping security agencies of the government, ranging from the State Intelligence Department to the Ministry for State

${ }^{262}$ Wills, p. 18

${ }^{263}$ Wills, p. 18 
Security and the Presidential special guard service. The line between law enforcement, security and intelligence work was blurred. There was agreement that the role of the intelligence community is to forecast threats, gather and analyse intelligence and provide it to policy-makers. ${ }^{264}$ Subsequent laws on the security and intelligence services have emphasized the legal mandate and values of the services, as well as listing control mechanisms. The relevant sections of the law applying to various modes of review and control are enumerated in the relevant sections of the present chapter.

The commitment to the rule of law has been reinforced in the law on the Georgian Intelligence Service, passed during spring 2010. Indeed, this latest law states that the service must respect the constitution and international treaties, in effect submitting the service to the law. ${ }^{265}$ Since it achieved independence in 1997, the State Intelligence Department and its successor agencies, up to and including the Georgian Intelligence Service, have emphasized the collection of foreign intelligence; however, the mandate for the collection of the majority of security intelligence fell under the Counter-Intelligence Department of the Ministry of Internal Affairs (MIA). The activities of the CID are much less transparent, although their successes are trumpeted whenever a new spy ring is discovered. There is a need to enshrine the role of the CID into legislation. While the former Law on the State Security Service is still valid, it remains unclear to what organization it applies.

However, in terms of the mandate of security and intelligence services, Robert Larsson underlines the importance of having a strategic document that charts the course of foreign and security policies, unless the state has a history of coherent policy in the

\footnotetext{
264 "Law Intelligence Activity", (1).

${ }^{265}$ Law on Georgia Intelligence Service, (2).
} 
field. ${ }^{266}$ This was lacking in Shevardnadze's Georgia. The 2005 National Security

Concept establishes itself as the basis for all governmental strategies and roots itself in liberal democratic values and national independence. It unmistakably states that EuroAtlantic integration is a national priority. The Concept clearly puts forward a number of values, national interests and threats. In terms of values, it leans directly towards liberaldemocratic values such as independence, freedom, democracy, rule of law, prosperity, security and peace. In terms of threats, priority is given to territorial integrity and national unity, as well as regional security and cooperation. The list of threats begins with infringements on territorial integrity, followed by potential spillover of other regional conflicts, military intervention, terrorism, organized crime, corruption and other categories that include the need to protect the environment, energy security and information technology infrastructures. To face these threats, the main directions given to Georgia's national security policy are the strengthening of institutions, military reform, restoration of territorial integrity, NATO and EU integration, foreign policy and regional partnerships, fighting international terrorism and organized crime. ${ }^{267}$ Overall, it is a holistic document with an emphasis on territorial integrity and strengthening state institutions. It charts the course towards further Euro-Atlantic integration with an emphasis on military reform but no mention of the role of the security services.

\section{Work in progress: the Serbian legal framework}

Until the emergence of a completely independent Serbia in 2006, the legal framework for the activities of the security and intelligence services was divided between

\footnotetext{
${ }^{206}$ Larsson, p. 13

${ }^{267}$ National Security Concept of Georgia (2005)

http://www.parliament.ge/files/292_880_927746_concept_en.pdf
} 
the federal level - first Yugoslav (1992-2002) and then under the State Union (to 2006) and the republican. Both legislatures passed a number of laws following the Bulldozer Revolution, although federal laws were annulled following the dissolution of the State Union of Serbia and Montenegro in 2006.

In 2002, the federal legislature passed the Law on the Security Services that introduced limited oversight over federal security services, mainly in the military and in the foreign service. ${ }^{268}$ A new legislative framework was also introduced to reform military intelligence, which was separated into two agencies: the Military Security Agency (Vojnobezbednosna Agencija, or VBA), which was responsible for counterintelligence and security; and the Military Intelligence Agency (Vojnoobaveštajna agencija, or VOA), which was responsible for gathering military intelligence. ${ }^{269}$ These agencies would continue to exist under the independent Serbian state. The Law on the Military Security Agency and Military Intelligence Agency was passed on 26 October 2009. ${ }^{270}$ These laws updated their federal predecessors and applied them to the agencies that now answered to the government of the Republic of Serbia.

As it has been previously mentioned, a 2002 law transformed the SDB into the new "security information agency", the BIA. The agency reported directly to the government, that is to say to the Prime Minister, and was provided with a legal framework that ensured some transparency and public accountability through legislative and judicial review. The mandate of the BIA centered on security-intelligence and the

\footnotetext{
${ }^{268}$ Edmunds, SSR Transforming, p.97

${ }^{269}$ P. Petrović, "Commentary on the Law on Military Security Agency and Military Intelligence Agency", Western Balkans Security Observer, N.15, 11-21, (October-December 2009), p.12

${ }^{270} \underline{\text { Ibid }}$
} 
agency "carries out tasks related to the security of Serbia."271 This vague mandate is not assisted by the measures for its control, achieved by "competent authorities" and government directives. ${ }^{272}$ The legal framework for the BIA has not been updated since this initial 2002 legislation, although other laws dealing with security and intelligence have been introduced.

Following the emergence of independent Serbia in 2006, a number of laws were passed to update the legal framework in which the security and intelligence services operate. It has been assessed that the new constitution provided a clear basis for democratic control of the security sector. ${ }^{273}$ The Law on the Basic Principles of the Organization of the Security Services in the Republic of Serbia was passed in late 2007, but it was criticized for a number of shortcomings. For one, it was seen as a missed opportunity to apply systematic rules to the entire intelligence apparatus and to replace outdated laws that still governed the services. ${ }^{274}$ The law provides an overview of the services through the legislature, the NSC, the president and the government although it does not include specific mechanisms to accomplish their mission. ${ }^{275}$

The completion of an adequately drafted and implemented legal framework providing a clear mandate and oversight for the agency along with an increasingly changing professional culture within the BIA is highly desirable and would serve as a

\footnotetext{
${ }^{271} \mathrm{BIA}$, Law on the Security Information Agency, (2).

${ }^{272}$ BIA, (4).

${ }^{273}$ A. Abusara, "What is it that Europe really wants: Analysis of the Progress Reports for the West Balkans' countries for 2009 in the case of civil and democratic control", Western Balkans Security Observer, N.15, 66-73, (October-December 2009), p.69

${ }^{274} \mathrm{P}$. Petrović "Incomplete step towards reform of the security intelligence system in Serbia - Critical retrospective view at the draft law on the basic structure of the Republic of Serbia security agencies" Western Balkans Security Observer, pp.108-114, (December 2007), p. 109;

B. Milosavljević, "A Review of the Proposed Law on the Security Services in the Republic of Serbia" Western Balkans Security Observer, iss.7-8, pp.102-107, (December 2007), p.103

${ }^{275}$ Ibid, p. 104
} 
catalyst for increased reform and efficiency. It has been indicated that the BIA is currently developing a new legal framework for its operations. ${ }^{276}$ The introduction of a bill will prove to be an excellent opportunity to engage legislators and civil society in a public debate on the role that BIA can play in the Serbian state.

\section{Conclusion}

As this section has demonstrated, the establishment of a clear legal mandate for the operations of the security and intelligence services is a key step in increasing accountability for the services. Such a framework sets clear boundaries for the actions of the security and intelligence services and highlight actions that are permissible and legal from those that are not. However, it is important to note that while it is very well and good to introduce a legal framework, it is imperative that it be fully enforced to be effective. This highlights the importance of political will to follow through and implement all of the relevant laws both in letter and in spirit. In both countries, existing laws can be strengthened or created. For example, the Georgian Counter-Intelligence Department still operates in secrecy without a clear legislative mandate. In Serbia, the law on BIA ought to be updated. Still, progress has been made and the focus should now turn to enforcing the implementation of the law. The successful implementation of legal provisions is dependent on the will of the political class in these countries, as well as on the good will of the leadership of the security and intelligence services. Monitoring the implementation of the law by the bureaucracy and the government falls within the responsibilities of the next two political powers, namely the legislative and judicial.

${ }^{276}$ HCHRS Serbia 2008, pp.198-199 


\section{Accountability to the people's representatives:}

\section{Legislative review}

As organs of the state, the real test for the accountability of the security and intelligence services remains in the establishment of proper legislative review. This permits the parliament to ensure that the services are acting in the respect of the law and of their mandate. The establishment of these review mechanisms brings together, once again, the challenges of ensuring the accountability of security and intelligence services as well as protecting the secrecy necessary for the operations of the services. In addition to executive control, legislative oversight provides a review of organizational, budgeting, personnel and legal aspects of the intelligence community. ${ }^{277}$ In so doing, it acts as a balance to ensure that there is not only executive control of the security sector, but also independent review through the legislature.

The main arguments in favour of the establishment of such mechanisms are that legislative oversight enhances accountability and ensures that the security services act in accordance with state, not political partisan, interests. ${ }^{278}$ As has been mentioned, the legislative review mechanism should be established in law and take into account all political parties represented in the legislature. ${ }^{279}$ Ideally, parliamentary control can bring a non-partisan approach to intelligence and help the efficiency of state agencies. ${ }^{280}$

Ensuring a cohesive national discussion on issues of security and intelligence can help forge a general position that will be a constant for security policy and the operations of the security and intelligence services.

\footnotetext{
${ }^{277}$ Bruneau \& Boraz, p. 15

${ }^{278}$ Hannah et al., p. 12

${ }^{279}$ Born \& Leigh, pp.85-86

${ }^{280}$ Venice Commission, p.33
} 
While legislative review is accomplished through a dedicated parliamentary committee in a number of countries, another option for external review can be found through an independent committee of experts that would report to parliament and have the necessary security vetting to examine the details of the security and intelligence services. Legitimacy for such a group would come through parliamentary approval. ${ }^{281} \mathrm{As}$ is the case for executive control, legislative review bodies must have proper civilian expertise for oversight to function in practice. ${ }^{282}$ It must also be kept in mind that building trust between members of the legislative review body and the security and intelligence services is as important as official mechanisms, permitting them to function effectively.

\section{Rubber stamp parliament: Legislative review in Georgia}

Since the elections of 2004, the Georgian legislature has been dominated by members of the United National Movement, the party of Mikheil Saakashivili. With the same party in control of the presidential palace and the legislature, the adoption of laws and review mechanisms was closely linked to government direction. There has been limited criticism from the legislature because of the government's dominance over parliament. ${ }^{283}$ This acceptance of government decisions limits the independence of the legislature in reviewing the activities of the security sector.

The Georgian legislature theoretically plays an important role in reviewing and controlling the security and intelligence service. It has the power to pass legislation

\footnotetext{
${ }^{281}$ Venice Commission, pp.6-7, 39

${ }^{282}$ Edmunds SSR Transforming, p.32

${ }^{283}$ Akubardia, Overview, p.31
} 
regulating the activities of the security sector and in approving the budget. ${ }^{284}$ However, the full legislature rarely has the occasion to review the activities of the security and intelligence services, unless it is in the process of passing or modifying legislation. Specific work dealing with the review of the security sector is delegated to a dedicated parliamentary committee. In Georgia it is conducted by the Defence and Security Committee, while specific budgetary revision is accomplished through a separate Trust Group. ${ }^{285}$ From 2007 to 2009 , the Defence and Security Committee played a formal role only, with little to no participation of civil society while in the period between 2005 and 2007 , the committee was more proactive in its work and in engaging civil society. ${ }^{286}$ This highlights the basic fact that legislative committees are only as effective as they wish to be: a more proactive committee will provide more oversight of the security sector than a less active one.

An additional legislative mechanism that permits the review of the Georgian security sector in more details is the Trust Group. The Trust Group is a small committee of parliamentarians with the necessary security clearance to review classified information, including budgetary information, from the security sector. While it originally consisted of three deputies, following protests and political manoeuvring on the part of the opposition it grew to six members in $2008 .{ }^{287}$ Because of its limited size and authority to examine classified information, the Trust Group has the necessary tools to provide effective legislative review of the intelligence services. ${ }^{288}$ Indeed, if there was a

\footnotetext{
${ }^{284}$ M. Vashakmadze, "Introduction - The Legal Framework of the Security Sector Governance in Georgia" in P.Fluri (Ed.) Security Sector Laws of Georgia, (2005).

${ }^{285}$ Law on Georgia Intelligence Service, (27).

${ }^{286}$ S. Lartkipanidze, Parliamentary Oversight of the Security Sector: Mechanism and Practice, pp.43-44

${ }^{287}$ Akubardia, Overview, p.32-33

${ }^{288}$ Lartkipanidze, p.47
} 
political will to do so, the Trust Group could have the ability not only to review the budget but to form the basis of operational review of the security and intelligence services while laying the foundation for long-term cooperation and trust between the review committee and the intelligence community.

However, analysts have had a pessimistic view of the powers of parliament in reviewing the security sector, which was dependent on an unstable political landscape and the inability of parliament to hire civilian expertise on the subject. ${ }^{289}$ The Georgian legal framework provides the legislature with the necessary authority to provide adequate review of the security and intelligence services, however when the parliamentary majority and the president are issued from the same party, political factors can hinder the level of oversight provided by parliamentarians. The factor that will ultimately determine its effectiveness will be the political will of parliamentarians to dedicate themselves to the efficient and in-depth review of the security sector and to overcome any partisan considerations in accomplishing this mission.

\section{Limited legislative review in Serbia}

The current legal framework allows for limited legislative review of the security and intelligence services. Although parliamentary control, public oversight and internal control of intelligence remain the core elements of proper review of the security services, the operation of such mechanisms remains tenuous in Serbia. While there is no mention of reporting to any specific legislative committee, the law pertaining to the BIA does state that the director of the agency must submit two reports per annum to the

\footnotetext{
${ }^{289}$ Vashakmadze, Introduction
} 
legislature ${ }^{290}$ Formally, the Defence and Security Committee has adequate authority but limits itself to discussing reports by intelligence agencies and do not conduct many field visits. ${ }^{291}$ Some steps have been taken as this committee was divided into two sections, which created the Committee for Security Services in July $2010 .{ }^{292}$ Still, increased legislative review of the security services would be beneficial and needs to have more substance than is currently the case. ${ }^{293}$ The development of a new legal framework for the BIA would need to firmly establish legislative review mechanisms to ensure an increased level of accountability to the legislature.

In addition to the need to reform existing legislation to strengthen the role of parliament, increased civilian expertise is needed. The expertise of parliamentary committees in security services remains week and legislators need to develop greater expertise and capacity; the input of civil society must be sought to improve the current situation. ${ }^{294}$ There is a pool of knowledge present in Serbian civil society; however, it has not been used to its full potential to benefit parliamentary knowledge of security and intelligence issues.

\section{Conclusion}

The ultimate role of the legislative branch is to serve as a counter-balance to the executive and to provide oversight and review of government actions. This role becomes more difficult when the president comes from the parliamentary majority and members of the same political party, which may be dependent on the president's leadership to ensure

\footnotetext{
${ }^{200}$ BIA, (17).

${ }^{291}$ Ejdus, p. 15

${ }^{292}$ Ejdus, p. 16

${ }^{293}$ Abusara, p. 70

${ }^{294}$ Ejdus, p. 29
} 
electoral viability, must provide a counterweight to the government's policies and actions. In both Georgia and Serbia, the main challenge to proper legislative review of the security and intelligence services is a lack of interest from the parliamentarians themselves which is partly explained by the fact that the governments of both countries possess a parliamentary majority which follows the leadership of a popular and powerful president. In Georgia, the parliament has the necessary legal powers to effectively review the work and financing of the security and intelligence services through the Trust Group. The proper political will could turn this committee into an efficient tool. On the other hand, the legislative obligations of the Serbian BIA are limited to submitting biannual reports to the parliament. These measures could be strengthened, especially as a new law on the BIA is being drafted. In addition to procedural and legal powers, legislative committees must ensure that they have the necessary independent expertise in security matters to assess developments in this sector, without fully depending on the security sector itself for information and research. A well briefed legislature, with the necessary tools and mechanisms and the will to effectively conduct its mission provides a crucial role in reviewing the actions of the security sector. To accomplish all of this, in addition to a clear legal framework, the judiciary is pivotal in enforcing the rule of law on the security and intelligence services.

\section{Gavels and spies: Judicial review}

Another mechanism to establish democratic control over the security and intelligence services is through judicial oversight. Judicial control provides independent review of the intelligence community and is occasionally supplemented by internal organizational legal reviews, such as inspectors-general. In many countries, the judiciary 
plays a proactive role by approving warrants for surveilling citizens. Retroactively, the judiciary can settle complaints and access to information demands. ${ }^{295}$ In addition to this role in authorizing operations within the state, the judiciary ensures that the intelligence services are accountable and do not operate outside the law. ${ }^{296}$ To be effectively implemented, judicial review must rely on the independence of the judiciary from the executive. This provides another example of the inter-dependence of intelligence reform on overall reform of the state. Through these means, the courts apply the law to the security and intelligence services in conjunction with the executive and legislative branches of government.

In addition to the courts and the issuing of warrants for surveillance, internal legal teams and the state prosecutor play an important role in assuring that the security and intelligence services are complying with the laws of the state that they protect. These internal mechanisms ensure the daily compliance of laws by the security and intelligence services. Internal legal departments serve to guide the services through the state's legal framework and to prevent illegal measures. Complementing this internal legal counselling, the role of the state prosecutor is to hold the services accountable and to emphasize that no one is above the law. Of course, these internal mechanisms are not perfect, but they serve to transform the organizational mentality of the security and intelligence services. Together, the subjection of the security and intelligence services to the state's judicial apparatus and the implementation of state and internal legal review firmly establish the security and intelligence services within the state's legal framework, dispelling the former view of the services as being above the law.

\footnotetext{
${ }^{295}$ Wills, p.33

${ }^{296}$ Wills, p. 15
} 
From the outset, security sector reform in Georgia has been based on the formulation of a legal framework to regulate the activities of this sector of government. Judicial control is established through the normal court system, which can review cases in which individual rights and freedoms might have been ignored. ${ }^{297}$ This places the security and intelligence services within the law. However, the success of this judicial review is mostly dependent on the institutional strength of the Georgian court system, which is currently weak. In addition to the courts, the state prosecutor can ensure legality, but does not have access to operational details. ${ }^{298}$ This approach limits the powers of the state prosecutor to investigate potential illegal activities within the security and intelligence services. Judicial reforms are also being implemented, but there remains a need for more independence from the executive branch. ${ }^{299}$ There is more work to be achieved in this sector, for while the judiciary is weak it cannot be expected to effectively deal with sensitive issues relating to the security sector.

In Serbia, while the law on the BIA remains vague in the realm of legislative review, it does contain some concrete elements to ensure the agency is subjected to the rule of law. The law on the BIA contains a number of elements that ensure judicial review and proactive control over the operations of the security intelligence service. For example, the allocation of surveillance warrants is subject to judicial probation by the President of the Serbian Supreme Court, or an authorized judge. ${ }^{300}$ In addition to these legal benchmarks, a number of ad hoc courts have played a role in bringing members of the security services to accountability.

\footnotetext{
297 "Law of Georgia: On the State Security Service", (20) in Fluri.

${ }^{298}$ Law on Georgia Intelligence Service, (28)

${ }^{299}$ EU Commission, p.5

${ }^{300}$ BIA, (14).
} 
Following Operation Sabre, a special court for organized crime in Serbia was formed and, when the public prosecutor filed the official charges on 20 August 2003, fifteen people were charged with the assassination, eighteen for seditious conspiracy and thirty-nine for criminal conspiracy. The list of indictees included Aco Tomić, the head of military intelligence and an associate of Koštunica. ${ }^{301}$ The main suspect, Milorad Luković, remained at large until he surrendered to police on 2 May 2004. The trials followed a tortuous route before concluding in 2007 , including a number of procedural difficulties, retractions and the disappearance of witnesses. ${ }^{302}$ To facilitate the administration of justice under the new government, a number of measures were taken. There was a purge of the judiciary to remove Milošević era judges, a move which created a pendulum effect where government intervention increased judicial dependence on politicians. ${ }^{303}$ As is the case in Georgia, the instauration of a solid and independent judiciary remains crucial to ensure that the security and intelligence services remain within their legal framework.

In both Georgia and Serbia, the main challenge to judicial review of the security services falls within the wider challenges of judicial reform. Only a strong, independent judiciary will have the capacity to ensure the accountability of the security and intelligence services. This is dependent on both the professionalism of the judiciary and non-interference by the executive and legislative branches of government.

\footnotetext{
${ }^{301}$ HCHRS Serbia 2003, pp. 124-125

${ }^{302}$ HCHRS Serbia 2005, p.188

${ }^{303}$ ICG, Serbian Reform, p. 12
} 


\section{Pushing for change from the outside: The involvement of the international community}

International involvement in the process of security and intelligence reform has had a direct impact on the local political scene, making the two levels difficult to separate. The international level examines the relations between states and international organizations, with an emphasis on the European Union and the North Atlantic Treaty Organization, as well as bilateral relations and assistance.

In his examination of the international level, Edmunds separates international involvement in security sector reform into three categories, namely, security assistance, pre-conditionality and conditionality. Security assistance is a form of bilateral aid between the state and international donors that is not attached to any particular condition.

${ }^{304}$ The other two categories discussed fall within the more general field of conditionality, namely, pre-conditionality and direct conditionality. For instance, the International Monetary Fund and bilateral loans come attached with a number of conditions and exemplify direct conditionality. On the other hand, the various criteria developed by NATO and the EU which may lead to eventual membership in these organizations exemplify pre-conditionality. ${ }^{305}$ There has been much debate surrounding the effectiveness of conditionality, as it is completely dependent on the presence of political will on the part of the local elites. Sometimes, conditionality could be detrimental to the long term success of reform efforts. Edmunds argues that there is limited effectiveness in direct conditionality because it puts direct pressure on civilian governments that may not have good control over the security sector and coercion may alienate the government and

\footnotetext{
${ }^{304}$ Edmunds SSR Transforming, pp.42-43

${ }^{305}$ Edmunds SSR Concepts, pp. 135-140
} 
public opinion. ${ }^{306}$ This underlines the importance of strong local ownership of the reform process, with a unique approach in each state instead of imposing a general mould to be applied uniformly.

The 1990s in Central and Eastern Europe saw the beginning of defence diplomacy which placed organizational reform of the security sector as a major foreign policy objective in light of Euro-Atlantic integration aspirations. ${ }^{307}$ There was a division of labour of sorts between the various international organizations; whereas NATO and the OSCE played an important role in developing military reform, the EU focused on nonmilitary security actors, such as police, judicial and border reform. ${ }^{308}$ This has been the case in the Southern Caucasus, where NATO has taken the lead in the security sector while the EU has had a more limited role, such as the European mission launched in 2004 to strengthen Georgia's judiciary. ${ }^{309}$ This can also be seen in the Balkans, where the EU has emphasized general government transformation as a pre-condition for membership while NATO has emphasized military reform.

The prospect of membership in Euro-Atlantic institutions has been one of the most efficient triggers for institutional reform in Central and Eastern European countries. Through exhaustive pre-conditions to membership, the EU and NATO have played an important role in security sector reform. However, the appeal of these regional organizations varies according to the likelihood of membership and the interest of these countries in obtaining membership. While Georgia places Euro-Atlantic integration at the core of its foreign policy, with special emphasis placed on NATO membership, Serbia's

\footnotetext{
${ }^{306}$ Edmunds SSR Concepts, pp. 140-141

${ }^{307}$ Edmunds SSR Transforming, p. 18

${ }^{308}$ Hänggi, p. 124

${ }^{309}$ Hänggi \& Tanner, p 57
} 
position has been less clear. Indeed, Serbia has shown little interest in NATO membership, an explanation for which can be easily be found in its ulterior experience with the alliance when NATO bombarded Serbia and intervened directly in Kosovo and the support of the majority of NATO member states for Kosovo's independence. Serbia is much more interested in the benefits of EU membership, although its main challenge has been cooperation with the ICTY in the capture of alleged fugitive war criminals. This confirms Edmunds' belief that pre-conditionality has shown its effectiveness through NATO membership, but it has had less impact on states that were less likely to join the alliance. $^{310}$

Ever since the Rose Revolution, the foreign policy priority of the Saakashvili government remains NATO membership. This policy orientation built upon the earlier steps taken by the Shevardnadze government from the late 1990s onwards. It has often been claimed that 1998 marked a clear shift in Georgian foreign policy towards the West. ${ }^{311}$ This interest has not been reciprocal, as Georgia remained of limited interest to Western powers, with the exception of the United States, that do not have historical relations to build on. Nor is there a coherent strategy towards the region. As a result, it is often assessed that Georgia will not gain membership in either the EU or NATO. ${ }^{312}$ The focus of the international community in Georgia has been on conflict resolution, as well as an emphasis towards internal security capacity building. ${ }^{313}$ While integration remains a top priority for the Georgian government, it will take much time before the country accedes to these organizations.

\footnotetext{
${ }^{310}$ Edmunds SSR Concepts, pp. 141-142

${ }^{311}$ Darchiashvili, p.131

${ }^{312}$ D. Helly \& G. Gogia "Georgian Security and the Role of the West" 271-305 in Coppieters \& Legvold, pp.271-272

${ }^{313}$ Helly \& Gogia, pp. 281-290
} 
While Serbia is in a better position to integrate into regional organizations, its relations with the international community have mainly been examined through the prism of the ICTY. While membership in the European Union is a priority for the Tadic government, this has not always been the case and has varied depending on the government in power. There is no consensus on the strategic direction that ought to be taken by Serbia between NATO integration and military neutrality. ${ }^{314}$ The country's stated policy of military neutrality precludes NATO membership, although Serbia remains active in some forums.

There was only limited international assistance for security sector reform between 2000 and 2002. There were a number of reasons for this reticence, namely, the limited cooperation of Serbian authorities with the ICTY and Serbian non-compliance with the Dayton Accords over support to Republika Srpska. ${ }^{315}$ Despite these difficulties, BIA has had bilateral assistance from the security and intelligence services of other countries. Officially, this assistance and training was provided to assist in the hunt for ICTY fugitives, but this assistance was mostly used to help Koštunica remain power under Rade Bulatović. ${ }^{316}$ Following the 2008 legislative election which brought a coalition led by Tadic's DS party into power, Serbia has made major gains with the capture of the three remaining ICTY fugitives in 2008 and 2011. With these successes, the last major political stumbling block to Serbia's European integration was removed and Serbia submitted a request for candidate status to the European Union during the fall of 2009.

The international community has had a direct impact on security and intelligence reform in Georgia and Serbia mainly through pre-conditionality. The opportunity of

\footnotetext{
${ }^{314}$ Ejdus, p. 11

${ }^{315}$ Edmunds SSR Transforming, p.214

${ }^{316}$ Intelligence Online, "Retour aux bonnes vielles méthodes; Belgrade" 4 October 2007.
} 
adherence to Euro-Atlantic institutions has been a good carrot, prompting internal reforms in these states in exchange for acceding to the benefits of membership. However, there are a number of limitations and problems in the international community's approach to security sector reform. The international community has limited influence on the reform process if the proposed benefits do not outweigh the local political costs of implementing these reforms, or if the potential benefits do not interest the local authorities. Indeed, the imposition of reforms and conditions by an external actor can cause resentment in the state and undermine the local government's political positioning. To be optimal, efforts by the international community must aim to support local initiatives and provide tangible benefits to the state in exchange for the effort.

\section{Conclusion}

Democratic control of the security sector is the result of more than the simple addition of the institutional mechanisms that have been described in the present section. Without the proper commitment and interest on the part of all the actors involved, these mechanisms are but formalities that exist on paper but not in reality. No country has completely and successfully achieved faultless democratic control over its security and intelligence services and both errors and scandals continue to plague the security services of even the most established liberal-democracies. Democratic control of intelligence and security services remains a fine balancing act between appropriate control and efficiency, while avoiding the politicization and instrumentalization of the services during political struggles.

Since the 2003 Rose Revolution, the Georgian political scene has remained dominated by the figure of Mikheil Saakashivili. While economic and institutional 
reforms remain priorities for the government, its authoritarian tendencies have increased since the November 2007 protests. This signifies that executive control has effectively been established over the security and intelligence sector; however, it also provides opportunities for the politicization of the services, as has indeed been the case. The legal framework for the workings of the security sector has been well established since before the Rose Revolution; the key to its success is its integral implementation. In this, and in keeping executive powers over the security and intelligence services in check, the legislature has an important role to play and there is a need to strengthen its position vis$\grave{a}$-vis the government. The same can be said of the judiciary. Following Gill's assessment model, the security and intelligence services are well on their way to the "security intelligence agencies" categories. However, there remains a risk that their instrumentalization by the political leadership may cause their status to regress back to that of a political police.

Contrary to the situation in Georgia, the political situation in Serbia, at least until 2008, was fragmented. This led to contradictory trends in the reform process with priorities shifting depending on the government in power. The legal framework for the security and intelligence services still needs to be updated. New legislation could provide an excellent opportunity to begin a comprehensive and open process that might bring together government, legislators and civil society in a national dialogue on intelligence.

Neither Georgia nor Serbia has experienced a smooth democratic transition since their respective revolutions. Challenges to political and institutional reform have come from within and without, but overall developments have been positive when compared to the situations which existed during the 1990s. Both countries have successfully 
established executive control over the security and intelligence services. In Georgia, the government has been in power since 2004 and has successfully imposed its stamp on the security sector. While this bodes well for civilian control over the security sector, it limits the effectiveness of legislative review and increases the odds of politicization of the security services. In Serbia, the establishment of executive control over the security and intelligence services took more time, challenged by political fragmentation and polarization, especially between 2000 and 2006. Executive control was eventually established, although institutional legacies from the 1990s remain. The current proWestern stance of the Tadić government establishes a clear direction for reform, but it must be kept in mind that politicization of the security services remains an ever present danger.

In both countries, there is an existing legal framework for the security and intelligence services that establishes the mandate and powers of these services; however, this can be strengthened, especially in terms of legislative and judicial review of the operations of the services. In addition to legal guarantees of appropriate review, legislators must be engaged in the workings of the security and intelligence services and develops a certain level of expertise. Additionally, a strong civil society is vital in providing transparency and examining the works of the security sector. Independent, and effective, media and NGOs serve as the public's watchdogs.

Following Gill's model, it can be said that the security and intelligence services are in the process of transforming from "political police" to "domestic security intelligence" missions. The reforms remain a work in progress and political will must 
exist for them to succeed. A lack of political will would only stall reform efforts and, especially if coupled with increased politicization, could lead to regression. 


\section{Chapter IV \\ Through the looking glass: \\ Examining the inner workings of the intelligence community}

Having examined the historical legacies of past intelligence agencies and the interaction between security and intelligence services and democratic institutions, the organization level will be examined in this section. This level of analysis is the most challenging to research, as operational secrecy is at the heart of the mission of the security and intelligence services. While intelligence reform aims at making the services more transparent and accountable, the internal operations of intelligence agencies the world over remain shrouded in secrecy.

This section, focusing on the organizational level of analysis, will follow Edmunds' model and examine internal changes in the services. In these cases, that typically means moving from protecting the regime to protecting society. ${ }^{317}$ As this section will emphasize, the main challenges to intelligence reform in Georgia and Serbia have centred on institutional continuity and the lack of strong political will for reform. While there have been organizational changes and transformations as ministries, departments and agencies were arranged and re-arranged, these superficial changes did not disturb the institutional legacy of the security and intelligence agencies. Organizational reform is essential to changing the institutional mentality that has been inherited from previous experiences. As this section will demonstrate, while external control mostly provides a review of the actions of the security and intelligence

${ }^{317}$ Edmunds SSR Transforming, p.34 
community ipso facto, the best guarantees of democratic control can be found within the services themselves through internal control mechanisms, accountability and the development of a professional approach to intelligence.

While most studies of intelligence reform have solely examined control mechanisms, it has been argued that there needs to be an examination of the positive impacts of intelligence reform. For example, it has been suggested that intelligence can drive the risk and threat assessments which serve as a basis for legitimacy and transparency, as well as serving to prioritize which threats must be addressed first in the process of security sector reform. ${ }^{318}$

Another method of examining the positive impacts of intelligence reform involves measuring the efficiency of the services. This is an especially difficult component to measure accurately, as intelligence successes are not nearly as publicized as intelligence failures. The discussion within the literature on the subject has largely been limited to establishing democratic control over the intelligence services without necessarily establishing benchmarks as to what constitutes increased efficiency for the services. Because of the bureaucratic nature of the intelligence community, the main indicators of efficiency can be found in institutional mechanisms. Many states choose to separate their security and intelligence services into two or more distinct agencies to limit the potential power of these organizations. However, as noted by Bruneau and Boraz, this division of labour may create silos between the various agencies, limiting the flow of information and potentially preventing crucial intelligence from reaching the appropriate authorities. ${ }^{319}$ To counter this, the authors argue in favour of institutional mechanisms to

\footnotetext{
${ }^{318}$ Wilson, p.90

${ }^{319}$ Bruneau \& Boraz, p. 17
} 
coordinate intelligence communities, as well as the development of "Team B" groups to challenge institutional thinking. ${ }^{320}$ However, these institutional mechanisms are only a part of the solution. For Edmunds, the most important element in organizational reform is the professionalization of the security sector that will provide for effective and efficient agencies under democratic civilian control. ${ }^{321}$ To assess the professionalism of intelligence and security services, the author provides a checklist of items that ensure professionalism, including a clear mandate limiting the role of the organization, the hiring of individuals with the proper expertise and adequate accountability for employees of the agency. ${ }^{322}$ There are several challenges to the hiring of a dedicated, professional staff in security and intelligence services, which derive from the institutional legacies of authoritarianism and conflict. In Central and East European countries, the main priority following the 1989 revolutions was to ensure the appointment of politically loyal staff. It was only in more recent years that there has been a new wave of reforms that fall more within second generation security sector reform and are aimed towards preventing internal corruption and increasing efficiency in the dealings of the services. ${ }^{323}$ In addition, the legacy of conflict can narrow the focus of the security sector, and personnel advancement can be based on exploits in the field rather than professional qualifications; the reform process needs to orient priorities towards peacetime objectives. ${ }^{324}$ These views are echoed by Ejdus, who states that in addition to structural challenges, the historical legacy of the security sector can hinder democratic transition. ${ }^{325}$ A prime example of this

\footnotetext{
${ }^{320}$ Ibid

321 Edmunds SSR Transforming, p.38

${ }^{322}$ Ibid, pp. $38-39$

${ }^{323} \frac{\text { Zorkin, pp.2-3 }}{324}$

${ }^{324}$ Edmunds, SSR Transforming, p.35

${ }^{325}$ Ejdus, p. 10
} 
can be found in the actions of the Serbian JSO that enabled the October 2000 revolution in return for being left with some latitude by the incoming government; it later rebelled by assassinating the prime minister when greater control was exerted.

The international community has been active in the organizational reform of the security and intelligence services in Georgia and Serbia, assisting through direct bilateral cooperation or through regional organizations such as the European Union and the North Atlantic Treaty Organization. Information relating to this is especially difficult to find in the public domain. International engagement in Georgia has centred on training and information sharing about Russia, while international involvement in Serbian organizational reform has centred on catching fugitives from the ICTY.

\section{Overview of the intelligence community}

Throughout most of the twentieth century, the institutional mandate of the Georgian and Serbian security and intelligence services was first and foremost to preserve and protect the regime. With the advent of the democratic revolutions in these two states, the new governments imposed a new mandate for the services. However, institutional legacies of the past remain deeply entrenched in these agencies, despite reorganization and name changes.

Typically, there are three types of intelligence agencies that constitute an intelligence community. The first of these, and the main focus of the present thesis, consists of domestic security intelligence services, which focus on internal threats. This domestic intelligence capacity can be balanced by the establishment of agencies responsible for gathering foreign intelligence, which is information gathered outside the boundaries of the national territory. Because of the high cost to the public treasury and 
the limited necessity of maintaining an independent foreign intelligence agency, some countries choose to combine domestic and foreign intelligence within a single organization, or may forgo foreign intelligence entirely. For example, Serbia does not have a dedicated foreign intelligence service. The third component of traditional intelligence communities includes military intelligence units that are dedicated to gathering intelligence that is of value for the armed forces and is usually more technical than political in its nature.

The intelligence communities in the two countries examined in this thesis have different missions and priorities. In Georgia, the government and media's emphasis has been on the establishment of effective foreign intelligence, mainly against Russia, while the role of security intelligence has largely remained in the shadows, coming out in the open following spy scandals. This can be explained by the state of the country's relations with Russia and the more appealing allure of foreign intelligence when compared to security intelligence. In contrast, intelligence reform in Serbia has centered on transforming the communist and Milošević era security services into a modern security intelligence agency. Serbia's geopolitical location in Southeastern Europe shelters the country from immediate external threats, making foreign intelligence less of a priority than in Georgia. In parallel to this reality, the information on both intelligence communities focuses on the emphasized intelligence branch: foreign in Georgia and domestic in Serbia.

\section{The 'Great Game' with Russia: The Georgian intelligence community}

The Georgian intelligence community emphasizes the role of foreign intelligence over that of domestic security intelligence. While the Serbian BIA has a clear mandate 
and presence in the media and research, in Georgia the emphasis has been on the foreign intelligence service. Information about the role of the domestic security service following the dissolution of the Ministry of State Security is hard to find, outside the occurrence of episodic spy scandals, when the Ministry of Internal Affairs' Counter Intelligence Department is briefly mentioned as responsible for the arrests, before receding into the shadows. Information about Georgian military intelligence is even more difficult to come by, as there is an overlap in the mission of the Georgian Intelligence Service (responsible for foreign intelligence) and that of the Ministry of Defence when it comes to the gathering of military intelligence.

The activities of the Georgian intelligence community as a whole are based in the Georgian Law on Intelligence Activity that was introduced under the Shevardnadze government. According to this legal document, the role of the intelligence community is built on a number of principles such as respect for the rule of law and human rights, as well as accountability to the president. ${ }^{326}$ Interestingly, responsibility to the parliament, or to the government, is not mentioned within the framework of the law.

Before the Rose Revolution, three government departments had responsibilities for intelligence functions in the Georgian government. The Ministry of State Security's State Intelligence Department had responsibility for foreign and domestic intelligence while the Ministry of Defence was responsible for military intelligence and the Ministry for Internal Affairs for border intelligence. ${ }^{327}$ During this period, the mandate of the MSS included what was then known as the state security service, which had a vague

\footnotetext{
326 "The law of Georgia: On Intelligence Activity" (5), in Fluri

${ }^{327}$ Ibid, (Art. 1).
} 
organizational delimitation to "special law-enforcement militarised establishments". ${ }^{328}$

Following the Rose Revolution, the MSS was dissolved and the responsibility for domestic intelligence was transferred to the Ministry of Internal Affairs and divided into a number of departments, notably the Counter-Intelligence Department and the Counterterrorism Centre. ${ }^{329}$ Unlike foreign intelligence, there has been little organizational reform in domestic intelligence institutions following the dissolution of the MSS. The original mandate of the state security service was to conduct counterintelligence operations, protect the constitution, counter organized crime and terrorism, as well as provide secure communications to government agencies. ${ }^{330}$ This large mandate remains the responsibility of the MIA, although the precise division of labour is murky. As will be discussed subsequently, the role of the MIA and the CID in domestic intelligence centres on the periodic arrest of Russian spies in Georgia.

In terms of foreign intelligence, the official history of the Georgian Intelligence Service traces well the acronymic nightmare that was its development since independence. Initially created as the Information-Intelligence Service, the phoenix of the former Georgian SSR's KGB, in 1991, it became the Main Division for Foreign Intelligence within the Ministry of State Security before becoming the independent State Department of Intelligence of Georgia in 1997. During this time, the regional offices that covered Adjara and Abkhazia were amalgamated into the central department. The organization remained independent until it was re-subordinated to the MSS in 2004, before emerging once more as an independent agency following wider institutional

\footnotetext{
328 "The Law of Georgia: On the State Security Service", (1), in Fluri.

${ }^{329}$ Georgian Intelligence Service History of Georgian Intelligence Service, http://www.gis.gov.ge/html/02 en.htm

330 "Law on State Security" (5), in Fluri.
} 
reforms which saw the absorption of the MSS by the Ministry of Internal Affairs. ${ }^{331}$ With the passing of the laws on Intelligence and Georgian Intelligence Service, the agency was renamed the Georgian Intelligence Service, the name by which it is currently known.

The role and mission of Georgian military intelligence remains extremely difficult to assess. There is limited open information available that deals with this particular branch of intelligence. For example, there has been some contradicting information about whether military intelligence even exists as an independent intelligence service. In his examination of the intelligence aspects of the 2008 conflict with Russia, Stéphane Lefebvre suggests that the arbitrary dissolution of military intelligence was a prime example of the inefficiency of Georgian intelligence. ${ }^{332}$ This information is disputed by Teona Akubardia who states that while military intelligence had been disbanded in 2005, it was restored in $2007 .^{333}$ It can be assumed that elements of the Ministry of Defence focus on military intelligence issues, regardless of whether there is a dedicated agency or not.

\section{The long shadow of the 1990s: Serbia's intelligence community}

At the moment of Milošević's fall, the Serbian security and intelligence services remained at the centre of the web of organized crime in the country. The combined heritage of the communist era and the wars of the 1990s left the services as a veritable state within a state; they acted in accordance with their own perceived interests, instead of being subordinated to the government. This situation persisted after the Bulldozer Revolution as the structures and staff of the security services remained in place. This

\footnotetext{
${ }^{331}$ Georgian Intelligence Service, History of Georgian Intelligence Service, http://www.gis.gov.ge/html/02_en.htm

${ }_{332}$ Lefebvre, p. 13

${ }^{333}$ Akubardia, Security and Defence, p. 13
} 
section will demonstrate that the institutional and personnel continuity in the services provided the main challenge to any reform efforts. Indeed, with some of the individuals responsible for the crimes of the 1990s remaining in positions of leadership, it could not be expected that reforms of any consequence would occur. This situation did evolve during the course of the decade, as the government established civilian control over the security and intelligence services and a number of structural and personnel changes occurred. While the Georgian intelligence community has been focused on countering foreign threats by emphasizing counter-intelligence and foreign intelligence, in Serbia the main threats have come from within and the emphasis has been on domestic intelligence, corruption, organized crime and tracking fugitives who had been indicted for war crimes by both Serbian and international tribunals. Throughout this period the priority for effective organizational reform centered on cleansing the services of organized crime and war criminals. The most problematic element of the security and intelligence sector was the continued presence of the JSO's Red Berets in governmental institutions, although these had been closely associated with the crimes of the Milošević regime.

As previously noted, one of the reasons for the success of the 5 October uprising was the deal that had been reached between Đinđić and Luković, the terms of which included that the JSO would not intervene to support the regime in exchange for remaining intact. In the months that followed the change of government, the SDB remained under the leadership of Marković, providing him with the opportunity to remove any incriminating files and to effectively cover his tracks. ${ }^{334}$ After his eventual removal in early 2001 as head of the SDB, allegations of collusion with organized crime continued to taint both levels of government. The Gavrilović case not only highlighted

${ }^{334}$ Edmunds, SSR Transforming, p. 178 
the tensions between the Koštunica and Đinđić camps but also fuelled allegations that separate crime syndicates supported both sides. ${ }^{335}$ This is hardly an example of effective reform of a state institution. Simultaneously, the use of the JSO for the arrest of war criminals, notably of Milošević, caused tensions in the government's relations with the unit, leading to the November 2001 strike. Although the unit was subsequently placed under the direct control of the MUP, it took the assassination of Zoran Đinđić by members of the unit before it was dissolved; while some of its members were arrested, others were simply transferred to other positions in the security sector. It must be noted that there had been some attempts at limiting the role and influence of the JSO by creating new forces responsible to the MUP, such as the Žandarmerija, a gendarmerie force that had been created in 2001 and was seen as a potential counterbalance to the JSO. ${ }^{336}$ During Operation Sabre, the Žandarmerija was at the forefront of the police operation; while questions were raised regarding its methods and the respect for human rights, the unit proved to be loyal to the government.

While armed paramilitary groups remained one of the most visible and intimidating elements of the security sector, the security and intelligence services remained in the shadows of the Milošević era. While Marković was removed as head, the SDB remained the same organization that it had been during the 1990s. Some organizational changes occurred in July 2002 when the SDB was abolished and replaced by the Security Information Agency (BIA), an independent organization responsible directly to the Prime Minister. The mandate of the new agency was set in law, granting it a role in both intelligence and counter-intelligence, though parliamentary control of the

\footnotetext{
${ }^{335}$ Intelligence Online, "Les confidences du colonel Gavrilovic" (23 août 2001)

${ }^{336}$ ICG Military, p. 13
} 
agency was limited to the submission of two annual reports to legislative committees. ${ }^{337}$ However, even with these changes, the organizational culture remained similar to that of the SDB and there was continued involvement by the security services in the shadow economy through front banks and arms trading. ${ }^{338}$ One change that proved to have some effect was the removal of the BIA from public policing as it focused more on its specified mandate. Edmunds observed that the BIA did shift its role from regime protection to state protection and cites as an example that the agency's priorities as stated in 2005 were related to counter-terrorism, a reflection of an alignment with the priorities of European intelligence services. ${ }^{339}$ The organization's impetus for profound reform ended abruptly following the election of Koštunica in late 2003.

During the years when Koštunica was in power, there were limited institutional and legal changes made to the security and intelligence services. There was political interference throughout the security and intelligence services as personnel that had been in the forefront of Operation Sabre, or any that were considered too close to the former DS government, were replaced by staff that was close to the new government. ${ }^{340} \mathrm{~A}$ prime example of this was the appointment of Rade Bulatović, who had been arrested and released without charges during Operation Sabre, as the director of the BIA. Political scandals and skeletons in BIA's closet continued to haunt the agency. For example, when revelations arose surrounding the cremation of bodies of those executed during the Milošević years, the MUP and BIA diverted attention away from the issue instead of

\footnotetext{
${ }^{337}$ CSD, pp. $45-46$

${ }^{338}$ ICG Serbian Reform Stalls Again, p.16

${ }^{339}$ Edmunds, SSR Transforming, p. 169

${ }^{340}$ HCHRS Serbia 2003, pp.116-117
} 
fully investigating these events. ${ }^{341}$ Another disturbing element is the allegation that the BIA still had some of the independent sources of income it inherited from the SDB, a situation accentuated by the fact that the act regulating procurement did not apply to the MUP or the DB/BIA, permitting these organizations to acquire material without proper oversight. ${ }^{342}$ However, there have been a number of developments since the election of Boris Tadić and his progressive government in 2008.

The year 2008 marked a shift in the development of BIA, which made a definitive move towards deeper reform efforts. The appointment of Saša Vukadinović as the agency's director in early July of that year occurred a few days before the capture of Radovan Karadžić. This fact has led some to conclude that all that was needed for the capture of Karadžić was a strong political will, which would be enforced by the appointment of a director who was close to the government and had the necessary support. ${ }^{343}$ Through this appointment, the director has the authority to organize and direct the activities of the agency, reporting to parliament twice a year. ${ }^{344}$ As has been noted, there are currently internal plans to reform BIA's legislative framework and it can be hoped that these efforts will be rewarded by a positive outcome. The success of reform efforts, when taken together with the capture of Ratko Mladić and Goran Hadžić in 2011, marks the completion of Serbia's task of hunting ICTY fugitives, opening the gates to European integration.

While most of the security and intelligence services remained under the direction of the republican level of government, the military counter-intelligence agency remained

\footnotetext{
${ }^{341}$ ICG Serbia: Spinning its Wheels, p.3

${ }^{342}$ Ibid, p.7

${ }^{343} \frac{1}{\text { Ejdus, p. } 14}$

${ }^{344}$ BIA, (Art.13).
} 
under the control of the federal government until Serbia's independence in 2006. During the final years of the Federal Republic of Yugoslavia, military counter-intelligence remained under the nominal control of the federal government, but this control was not always effective. A stunning example of this occurred on 14 March 2002, when military counter-intelligence arrested the Serbian Vice President, former VJ commander Momčilo Perišić and an American diplomat without any civilian direction; it had been alleged that Perišić had been passing secret information to the United States. ${ }^{345}$ This action, which was taken without civilian control and undermined relations with a key foreign benefactor, further damaged the country's reputation. While the Serbian government apologized and acknowledged that there was a lack of civilian control of the security services, and the Serbian Minister of Justice claimed that military intelligence had broken the law, at the federal level, the $\mathrm{VJ}$ and federal president Koštunica stated that the operation had been perfectly legal. ${ }^{346}$ This incident highlights the recurring theme of Koštunica's laissez-faire attitude with regard to security and intelligence reform in Serbia.

Organizational reforms to military intelligence occurred when Koštunica's position disappeared with the dissolution of the Federal Republic of Yugoslavia and the creation of the State Union of Serbia and Montenegro. With his departure, the army lost a protector. Following this, the General Staff and military intelligence were placed under the authority of the Ministry of Defence and military intelligence was instituted into two separate agencies in 2003: the Military Security Agency (VBA) and the Military

\footnotetext{
${ }^{345}$ ICG Fighting Control Military, pp. 1-2

${ }^{346} \underline{\text { Ibid,p. } 2}$
} 
Intelligence Agency (VOA) ${ }^{347}$ This move towards two distinct agencies responsible for military intelligence has had its supporters and critics; the latter insist that Serbia is going against international trends by opting for two separate agencies. However, on the other hand, this division of labour can strengthen military intelligence as the different missions and expertise can be channelled into dedicated agencies instead of being housed under the same umbrella organization. ${ }^{348}$ While the VOA is responsible for military intelligence gathered abroad, the VBA has the mandate to carry domestic surveillance and intelligence gathering but requires the permission of the Supreme Court to engage in monitoring and surveillance for a period of three months. ${ }^{349}$ The effectiveness of this new arrangement was demonstrated in July 2008 when the VBA, with the participation of BIA, arrested Karadžić. ${ }^{350}$

In the decade following the 5 October revolution, the Serbian intelligence community has undergone some reform, the results of which are slowly beginning to appear. The main challenges to these reform efforts lay in the institutional continuity following the fall of the Milošević regime and in the lack of strong political will. However, the impetus for reform has gained steam since Serbia emerged as an independent state in 2006 and has accelerated since 2008 .

\footnotetext{
${ }^{347}$ CSD, p.65

${ }^{348}$ Petrović Military, p.13

${ }^{349}$ Ibid, p. 14, 20

350 Intelligence Online, "Tadić Takes Agencies in Hand", (24 July 2008).
} 


\section{A failure to face the past: Lustration attempts in Georgia and Serbia}

Security and intelligence services are built on their previous institutional legacy, which in the case of Georgia and Serbia meant relying on staff and practices that may have been active in repressing the population under the previous regime. One way of breaking the legacy of the past has been to interdict former elites that had been politically active or had a hand in repression from holding office. These efforts, known as lustration, have had varying degrees of success in Central and Eastern Europe. There have been limited attempts in both Georgia and Serbia at lustration, but these have mostly ignored some of the important aspects, and its spirit.

Lustration efforts in Georgia have been relatively recent and limited to wider legislative issues. After several calls for a law on lustration since 2005, a law introduced in May 2011 combined limited lustration efforts and new anti-terrorism elements. An opposition deputy close to the government introduced this law, modelled on the USA Patriot Act. In addition to interdicting the display of Nazi and Soviet artefacts, the law restricts the access to public office for former Soviet functionaries and the names of former KGB officials are released to a commission responsible for applying the provisions of the law. ${ }^{351}$ The simple fact that lustration efforts have been buried within a wider law highlights the limited importance that is given to this subject in Georgia. In addition, it does not address officials that may have been active during the years of civil war or under the Shevardnadze government.

Lustration efforts have been limited in Serbia as well. The law that has been introduced to deal with this issue is applied directly to those that are proven to have a

\footnotetext{
${ }^{351}$ Economist Intelligence Unit, 'Country Report : Georgia', June 2011.

Civil Georgia, "Parliament Passes 'Liberty Charter"' (31 May 2011)

http:/www.civil.ge/eng/article.php?id $=23560$
} 
responsibility for violating human rights. ${ }^{352}$ This law aimed to penalize those that had done more than simply become members in specific organizations or political parties. ${ }^{353}$ As such, it did not permit the widespread removal of Milošević era officials and targeted those that were proven to have directly infringed human rights, accusations that can be hard to prove in the secretive world of the security services. A number of factors explain its ineffectiveness such as a lack of social consensus and the politicization of this issue as the government of the day uses clauses of this law to remove potential opponents. ${ }^{354}$ In addition, there has been strong political opposition to lustration efforts by the political class, a political class in which many had supported Milošević at one point or another during the 1990s.

Belgrade and Tbilisi have both been reluctant to directly confront the legacies of the past. Lustration attempts have been limited to certain individuals in the case of Serbia and have ignored officials that were in power during the 1990s in Georgia. Although there have been a number of organizational transformations in both countries following the revolutions, few have the specialized knowledge required to work in the security and intelligence services, limiting the pool of qualified candidates to those that had previously been employed by these services. Limited lustration means that there remains the possibility that the institutional mentality present during the 1990s remain in place in the services. In the absence of meaningful lustration, internal control mechanisms can serve to establish clear boundaries in the operations of the security and intelligence services.

\footnotetext{
${ }^{352}$ Rakić-Vodinelić, V. "An Unsuccessful Attempt of Lustration in Serbia", in Lustration and consolidation of democracy and the rule of law in Central and Eastern Europe, V. Dvořáková, and A. Milardović, editors, pp.169-182 (Zagreb, 2007), p.171

353 Ibid

${ }^{354}$ Ibid, p. 172
} 


\section{Internal control mechanisms}

The principal guarantee for the democratic control of the security and intelligence services is the existence of internal mechanisms regulating the day-to-day activities of these agencies. In addition to external control, there needs to be internal control which includes but is not limited to creating mechanisms that permit employees to report questionable and improper activities internally to senior administrators, and protect whistle-blowers. Such mechanisms can be strengthened by a professional code of ethics that is established internally. ${ }^{355} \mathrm{~A}$ clear hierarchy and decision-making process is decisive to ensuring accountability and transparency in the security services. Other internal means include good human resources support, including psychological services. ${ }^{356}$ The establishment of professional norms for personnel, along with good work conditions, brings the dual advantage of augmenting the efficiency and accountability of the intelligence community.

Other governmental officials can also play a role in ensuring the democratic control of the services, through various means. Echoing this viewpoint, the 2007 Venice Commission report discusses the importance of having an internal inspector-general who can investigate potential complaints originating both internally and from the public. ${ }^{357}$ In addition to independent inspectors general and ombudsmen responsible for processing complaints and grievances, state auditors general play a key role in providing expenditure reviews although it must be emphasized that these independent review agencies ought to

\footnotetext{
${ }^{355}$ Born \& Leigh, pp.46-49

${ }^{356}$ Venice Commission, p. 30

${ }^{357}$ Ibid, pp.6-7
} 
be based in legislation. ${ }^{358}$ While this remains a work in progress, some success has been achieved on these fronts in both Georgia and Serbia.

Unfortunately, Georgia does not have clear internal control mechanisms and there is no specific mention of an ombudsman-like position either in the legal texts or the media. Budgetary approval and institutional accountability rely on regular governmental mechanisms, through the NSC. However, law forbids participation in the political sphere by members of the state security service. ${ }^{359}$ More progress has been accomplished in the field of social benefits for personnel. As a legacy of the privileges enjoyed by members of the security services during the Soviet period, and the regime's need for loyalty during the 1990s, current professional benefits for employees of the Georgian Intelligence Service are enshrined in law. ${ }^{360}$ While employment benefits and employment security will ensure that the agency remains attractive for potential employees, the establishment of internal review mechanisms will reinforce the accountability of the security and intelligence services. In addition, increased legislation would be needed of the CounterIntelligence Department although there are no indications that these changes will happen in the near future.

More internal mechanisms exist in Serbia, where a number of independent mechanisms have been introduced through legislation, although scholars and NGOs have criticized their limited implementation. There are a number of governmental regulatory agencies, such as the Ombudsperson, the Commissioner for Information of Public Importance and Personal Data Protection, the Anti-Corruption Agency, and the State

\footnotetext{
${ }_{358}^{358}$ Born \& Leigh, pp. 105-107, pp.114-115, Bruneau \& Boraz, pp.15-16

359 "Law on State Security", (2)

${ }^{360}$ Law on Intelligence Activity (16), in Fluri.
} 
Audit Institution. ${ }^{361}$ The BIA had resisted access to information requests, but this changed with the appointment of a new director in $2008 .^{362}$ Oversight is the responsibility of the Ombudsman and of the Commissioner for Information of Public Importance and Personal Data Protection. While this oversight extends to all government departments, it does not extend to the Presidency, the National Assembly, the cabinet and the judicial system. ${ }^{363}$ This indicates that the civil service is submitted to the authority of these bodies but that the political class remains outside their reach. In addition, these control mechanisms have been established but need to be implemented "in spirit and in letter", as well as consolidated. ${ }^{364}$ The internal mechanisms built for the control of the BIA are complemented by those responsible for military intelligence, where both agencies have an inspector general responsible for internal control of the security agencies, although the law is vague on the tools used for this purpose. The inspectors general must have nine years of experience in the domain, which means that they will usually come from within the intelligence community; this is in effect, a double-edged sword. ${ }^{365}$ There was little to no oversight of military intelligence until recently, and although the position of Inspector General was created, it was not filled. ${ }^{366}$ Ejdus reflects negatively on the fact that directors and inspectors general of military agencies do not have to be reviewed by the Committee on Security and Defence. ${ }^{367}$ The presence of multiple internal control mechanisms, once they are all successfully implemented, will

\footnotetext{
${ }^{361}$ Ejdus, p. 17

${ }^{362}$ Ejdus, 25

${ }^{363}$ Popović, p. 37

${ }^{364}$ Ejdus, p. 28

${ }^{365}$ Petrovic Commentary p.18-19

${ }^{366}$ Ejdus, p. 13

${ }^{367}$ Petrović Commentary, p. 15
} 
assure proper internal control in the Serbian intelligence community. However, much like Georgia, Serbia's approach to second generation security sector reform is unbalanced.

Ultimately, the guarantee for effective control of the security and intelligence services come from within. This can be accomplished through the creation of internal control mechanisms, such as an inspector-general or an ombudsman, as well as through a professionalization of the service members. While Georgia emphasizes professionalization and the strengthening of personnel development, Serbia clearly emphasizes the internal mechanisms that can control the intelligence community. This reality builds into varying needs of these two countries, as Serbia focuses on breaking down the legacy of its past while Georgia emphasizes successful intelligence that can safeguard the state and the administration of the day.

\section{Efficiency in the intelligence community}

The establishment of democratic control over the security and intelligence services is the main but not the only element of intelligence reform. The following section will attempt to examine the measures that have been taken in Georgia and Serbia to increase the effectiveness of the security and intelligence agencies in the completion of their tasks and mandates. It will examine institutional mechanisms created to ensure that information and directives flow within organizations and throughout the intelligence community effectively so that the community may provide policy makers with timely, relevant and accurate intelligence. The effectiveness of these measures cannot be measured precisely because of the secretive nature of the information that transits, however some hints of effectiveness of these channels can be found in the successful, or unsuccessful, results of intelligence operations. 
The first institutional mechanism that is usually mentioned is the creation of a body to coordinate the intelligence community to ensure both a proper flow of information and adequate executive control. In addition to these mechanisms, the development of what Edmunds refers to as 'second generation security sector reform' is based on internal factors such as the professionalization of the intelligence services, the development of proper human resources systems and continued training to ensure that members of the intelligence community develop to their full potential, thus increasing the effectiveness of the intelligence community.

In Georgia and Serbia, the means of measuring the effectiveness of the security and intelligence services are varied. While both countries have adopted centralised coordinating bodies to oversee the security sector, information about the effectiveness of their intelligence services is not so clear. Indeed, the difficulty of finding open information about any intelligence service often results in the assumption that things are going smoothly as long as there are no major attacks or scandals. However, this can be deceiving. In the case of Georgia, the country's spy war with Russia will be examined as a way of assessing the performance of the intelligence service. For Serbia, the task is more complex as the main public element of the reform of the security and intelligence services has been the hunt for ICTY fugitives. This can be a good barometer as the inability or failure to capture these alleged war criminals has been a very divisive issue for the security services.

\section{Aerial acrobatics: Coordination of the intelligence community}

The creation of central bodies with the mandate to coordinate the security sector is an important step in the establishment of effective executive control. Indeed, the role of 
national security governance, which usually takes the form of a central national security council, "[...] is always to bring the disparate parts of the security agenda together." 368 These councils can take a more advisory role or an executive role, depending on local preferences, though an executive structure ensures centralized decision-making processes. ${ }^{369}$ In both Serbia and Georgia, national security councils were established under the authority of the president, echoing the institutional structure of the US National Security Council.

The Georgian National Security Council (NSC) was created during the Shevardnadze years as a means of securing the control of the country's disparate security sector. The NSC is a part of the presidential administration and is responsible to the president, not to parliament. ${ }^{370}$ The legal foundation for the Georgian NSC is based on both the country's constitution and the relevant law, providing the institution with a very strong legal basis. The NSC is responsible for analysing and coordinating the activities of the Georgian security sector and acts as a decision-making body. The NSC continues to play an important role in supporting the Georgian president in foreign and security policy, however it tends to serve more as a top-down mechanism to control the security sector than as a setting for sharing information. It remains unclear what impacts the NSC has had in decision-making and whether it was used to its full potential.

In Serbia, institutional mechanisms were created to streamline government control and coordination of the security sector. The Serbian NSC was established in 2002 but it had no authority over federal agencies and little control over republican agencies and as

\footnotetext{
${ }^{368}$ S. Bean, O. Oliver; K. A. O'Brien, A. Rathmell "National Security Decision-Making Structures and Security Sector Reform" RAND Europe Technical Report, (2005), p.2

${ }^{369}$ Bean \& al., pp.23, 25

${ }^{370}$ Vashakmadze, 2004.
} 
such quickly became unused. This situation was partly remedied when the NSC was revived and reformed in 2006, following Serbia's full independence and the election of Tadic as president. The NSC was given authority over intelligence issues and priority was given to cooperation with the ICTY. ${ }^{371}$ The NSC was created as a means of coordinating the security services and is composed of the President, Prime Minister, ministers of defence and interior, as well as the heads of the relevant agencies who attend council meetings. However, some have found it lacking because of the absence of the Minister of Foreign Affairs, a notable flaw considering the importance of foreign issues to national security. ${ }^{372}$ The NSC was established with three main areas of responsibility: overall national security; the direction and coordination of the security services; and, the protection of privacy and human rights issues. ${ }^{373}$ Since its revival in 2006, the NSC has served as a key instrument as a means of controlling and coordinating the sector. While this is due to a number of factors, the capture of the remaining ICTY fugitives highlights the successful accomplishment of the NSC's priority.

The presence of national security councils in these countries illustrates the commitment of governments to control and coordinate the intelligence community. In both countries, NSCs have served as the main mechanisms to control the security sector, providing a top-down approach to coordination. It remains unclear how effective the NSCs are in facilitating the flow of information between government institutions or in facilitating the flow of intelligence to the head of the executive. Based on general observations, the Serbian NSC has achieved its priority assignment, the capture of remaining ICTY fugitives, although its precise role in this manner is unclear. The

\footnotetext{
${ }^{371}$ Ejdus, p. 12

${ }_{372}$ Petrović Incomplete, p. 110

${ }^{373}$ Milosavlejecic Review, p. 105
} 
Georgian security sector has successfully discovered a number of alleged spy rings, however it also undertook the disastrous attack on South Ossetia during the summer of 2008, causing war with Russia. The flow of intelligence from, as well as the influence of, the NSC on political decision-making remains unclear, but it can be assumed that this remains very much a top-down approach where conclusions are stated and the necessary evidence is gathered accordingly. These realities reflect that the presence of such central coordination mechanisms create the opportunity for increased efficiency and also provide potential for the politicization of the security and intelligence services.

\section{The reality test: Organizational efficiency in Georgia and Serbia}

The main concern of the Georgian intelligence services remains the de facto governments of the secessionist regions and their backers in Moscow. This has led to a decade-long game of cat and mouse between the Russian and Georgian intelligence services, during which various 'spy rings' were uncovered on both sides of the border. This continued cold war, which did turn quite hot during August 2008, remains the most public yardstick against which the efficiency of the Georgian intelligence services can be compared. Tensions between Russia and Georgia go back to Georgia's independence, when Russian troops actively supported the secessionist forces in South Ossetia and Abkhazia. The presence of Russian military forces on the ground in Georgia under the cover of the joint-peacekeeping force in these two regions continued to aggravate the Georgian government, which responded by turning a blind eye to the presence of Chechen forces using the Pankisi gorge as a base for launching offensives against 
Russian forces in the northern Caucasus. ${ }^{374}$ Following the 11 September 2001 attacks and the subsequent global reaction of the United States government, the Georgian authorities were pressured into sending security forces into the gorge to mop up Chechen militants. Tensions between Georgia and Russia escalated following the Rose Revolution as the new government increased ties with the US and NATO.

There have been numerous spying scandals concerning Georgia and Russia over the past years. Tensions with the secessionist areas were aggravated following 2004 and were followed by the 2006 spy scandal that led to the suspension of diplomatic relations between the two countries and the introduction of Russian economic sanctions against Georgia. This was followed by spy scandals at the time of the 2007 opposition protests. The 2008 conflict with Russia highlighted a number of flaws in Georgian intelligence. In the lead up to the conflict, Russian security services went on record stating that Georgian intelligence had an active network in Russia. Following the arrest of a Chechen in May 2008, nine alleged Georgian spies were detained on 11 August and on the same day a senior Russian military commander was accused of having spied for the Georgians since late $2007 .{ }^{375}$ However, Georgian intelligence failed to monitor Russian troop movements and to anticipate the Russian intervention, despite the fact that Russia is the primary target of Georgian intelligence agencies. ${ }^{376}$ This does not bode well for the future.

Since the 2008 war there continue to be spy scandals. Two recent examples include the November 2010 arrests, as well as the arrest of four photojournalists, two of who worked respectively for the presidential press office and the foreign ministry's press

\footnotetext{
${ }^{374}$ S. Lefebvre, "Intelligence Aspect of the 2008 Russia-Georgia Conflict", Journal of Slavic Military Studies, pp.4-19, p.7

${ }^{375}$ Ibid, p.7

${ }^{376}$ Ibid p.6, 13
} 
office. The arrests surrounding both alleged spy rings were widely publicised as a resounding success by the Interior Ministry. In both cases, the Ministry of Internal Affairs proudly displayed video confessions of some of the accused spies on its website. ${ }^{377}$ The apparent successes of these operations signal the effectiveness of Georgian counter-intelligence. However, the continued discovery of spy rings in the circles of power and within opposition movements can very well lead to the presumption that not all of the arrests made by the CID are politically objective. It would not be the first time that an external threat was used to justify attacks on the political opposition.

There have been a number of changes in the Georgian intelligence community since the 2008 conflict, following the course of reform initiated before the conflict. In his analysis, Lefebvre notes that one of the main flaws in Georgian intelligence was the lack of experienced analysts and the drastic downsizing that the organization went through. ${ }^{378}$ In an attempt to overcome these challenges, the agency's director has publicly announced efforts at reforming the foreign intelligence service through the strengthening of the agency's analytical capacity as well as striving for a more efficient use of resources and an increase in the organization's budget. ${ }^{379}$ In addition, the director has been a proponent of a strong legislative framework for the intelligence community to ensure order and efficiency. These efforts seem to have come to fruition with the passing of the new law on the Georgian Intelligence Service during spring 2010.

\footnotetext{
${ }^{377}$ Statement of the Ministry of Internal Affairs, (9 July 2011), http: $/$ www.police.ge/index.php" $m=8$ \&newsid $=2642$ Ministry of Internal Affairs of Georgia detained several persons covertly working for GRU, (5 November 2010), http://www.police.ge/index.php? $\mathrm{m}=8$ \&newsid=1669

${ }^{378}$ Lefebvre, p.9, 11 .

${ }^{379}$ L. Girsiashvili, "Georgia needs strong and effective intelligence service", 24 Saati, (25 February 2008), retrieved on 12 April 2011 from http://www.gis.gov.ge/html/08 _ en.htm
} 
While Georgia has had the Russian issue with which to test its capacities, in Serbia the onus has very much been on cooperation with the ICTY. Cooperation between the ICTY and the Serbian government has not always been easy. Following the initial arrest of a number of ICTY inductees, progress stalled during the Koštunica years. The year 2008 marked a change with the capture of Karadžić and increasing cooperation with international actors; it has been suggested that British and American intelligence agencies provided information that contributed to the arrest. ${ }^{380}$ In addition, the capture of the remaining two alleged war criminals lingered as a condition to eventual Serbian membership in the European Union. During the course of Vukadinović's directorship, cooperation with the ICTY reached new heights while the BIA moved to establish close cooperation with fifty-five security and intelligence services from forty countries. ${ }^{381}$ There was widespread speculation that the arrest of Ratko Mladić was imminent in the months that followed Karadžić's arrest, as the international community called for his arrest. Then, during the course of 2011, the last two fugitives were captured by Serbian security services: Mladić in May and Goran Hadžić in July $20111^{382}$ It can be hoped that this marked the end of Serbia's difficult relations with the ICTY, although the capture of fugitives does not mark the end of cooperation between Belgrade and The Hague and there may remain grounds for future tensions related to the trials of these alleged war criminals. The case of Serbia's cooperation with the ICTY is an interesting one, as it highlights not only the issue of efficiency, but of political will. The major fugitives were only captured after a pro-Western government was elected, as had been the case earlier in

\footnotetext{
${ }^{380}$ C. O'Reilly, 'Serbia extradites Kradzic to Hague”, Jane's Intelligence Review (July 2008).

${ }^{381}$ B92, "Serbia has 55 security services from 40 countries: spy agency chief", BBC Monitoring Services, (13 January 2010).

${ }_{382}$ FAZ Net, "Mutmasslicher Kriegsverbrecher Hadzic gefasst", Frankfurter Allgemeine Zeitung, (20 July 2011), www.faz.net $-02086 \mathrm{v}$
} 
the decade, which leads to the conclusion that the determining factor in successful intelligence reform remains strong political will.

\section{Conclusion}

The organizational level is the most important in any assessment of the lasting impact of intelligence reform efforts, yet it is the most difficult to research. It is through the organizational level that exists the best insurance for democratically controlled and highly efficient intelligence services. The internal reform of the intelligence services of Georgia and Serbia was quite different, the common element of which was the fact that political will, in conjunction with firm executive control over the services, was the most important variable determining the success or failure of intelligence services. In both countries there was a strong element of institutional continuity in the intelligence community following the successful revolutions. The precedent set by the Central Bank of Serbia, while drastic, may have provided a solution to balancing competence and breaking with the past. By dismissing all the Bank's employees and making their reemployment conditional on a successful competition for their old positions, the new leadership ensured that only competent employees were rehired. In Georgia, the mass dismissal of the police force following the accession to power of the Saakashvili administration also follows this type of approach. Unfortunately, this was never applied to the security and intelligence services and until natural attrition causes a full replacement by staff instilled with new values, the lingering legacy of the past will remain in place within the services.

In Georgia, executive control by the new government was swiftly implemented as the impetus for reform moved forward. However, the main hindrance to proper reform 
remains the politicization of the security and intelligence services as they are used to score political points by raising fears of Russia and lambasting the opposition as the enemy's pawns. When confronted to the threat of conflict, Georgian intelligence reacted poorly as it failed to draw the conclusion that Russian forces would actively intervene in any conflict in South Ossetia. This fact must be taken with a grain a salt as it is unknown what advice the intelligence community gave the government. A positive aspect of Georgia's organizational reform is the important role given to working conditions for employees and the opportunities for career development. However, there remains much room for improvement, most critically in terms of operational independence from political decision-makers. The institutional mentality must be transformed and the services must continuously focus on their non-partisan mission and not turn into agents bent on protecting and providing the government with positive media coverage.

In Serbia, information about the professionalization of agency employees is scarcer. A number of internal mechanisms have been created and are being implemented. In terms of perceived efficiency, the agencies' progress in the capture of alleged war criminals has depended mainly on the government in power. During the period from 2000 to 2003 , the Serbian government captured a number of fugitives, most notably in the course of Operation Sabre, under the leadership of the DS government. This was followed by stagnation between 2003 and 2008, until the return of a DS-led government in 2008, when renewed emphasis was again placed on capturing the remaining war criminals sought by the ICTY. This leads to the conclusion that even though the Serbian security and intelligence services had institutional continuation from their legacy agencies, the challenges this reality poses can be limited if the government applies its 
control and political will to reform efforts, or in this case to cooperation with international institutions.

In terms of applying the progress of intelligence reform in both Georgia and Serbia, security and intelligence agencies remain between the role of political police and that of the domestic intelligence bureau. The future trajectory, either continuing reform or returning towards the role of a political police, will depend on the institutional leadership as well as the political will to achieve these reforms. 


\section{Conclusion: Intelligent design?}

States undergoing democratic transition face a number of important challenges. One of the most significant is the need to establish control of and reform the security sector in order to break with past legacies of repression. This is especially true in the case of the security and intelligence services that had often played the role of a political police protecting the regime in power. The approaches towards this issue have varied from country to country, with policies ranging from the pure and simple mass dismissal of staff and dissolution of the service to the mere continuation of the activities of the security and intelligence community under new management. In the cases of Georgia and Serbia, the course of action was somewhere between these two paths, as the new governments applied their stamp on the security services.

Three years separated the Serbian and Georgian popular uprisings that ousted the corrupt governments of Milošević and Shevardnadze. While it might be expected that Serbia has had the advantage of time, a number of elements can be counted in favour of the reform efforts in Georgia. The incoming democratic government in Georgia faced fewer internal challenges to reform than had been the case in Serbia. During the entire period since the Rose Revolution, the Georgian political landscape has been dominated by President Mikheil Saakashvili and the ruling United National Movement. This has given the government ample opportunity to apply desired reforms in a consistent and comprehensive manner. While this has been done with relative success throughout various fields of political and economic governance, the reforms of the security and intelligence services remain, as this thesis has demonstrated, a work in progress. Because 
of the political stability of the ruling party, ultimate responsibility for the relatively limited reform is to be found in the lack of sustained political will for reform. When compared to the situation in 1993, security sector reform has been a resounding success, as the central government re-established control over the security sector, eliminating the multitude of paramilitary units that had emerged under the control of various war lords during the years of civil war. However, Adjara remained under the autonomous leadership of the local political boss, the power ministries remained fairly independent bases of power while the police was notoriously corrupt and incompetent. There were initial successes following the Rose Revolution, as the security services were demilitarized, the Ministry of State Security was dissolved and all police powers, as well as counter-intelligence and counter-terrorism, were transferred to the Ministry of Internal Affairs. During its first year of governance, the Saakashvili government managed to reestablish central control over Adjara but this success was not repeated in the other secessionist areas. With Russia as a backer, the secessionist regions had a powerful ally to bring pressure on Tbilisi, pressure that exponentially augmented with the deteriorating relations and increasing hostilities between the two countries.

This continued external pressure contributed to the formation of an institutional siege mentality that infected views on internal security intelligence. This was seen time and time again since the Rose Revolution, ranging from events such as opposition rallies being linked to alleged Russian plots to undermine the government to the recurring discovery of alleged spy rings which are often settled outside of the courts and left unresolved. This trend was accentuated with the 2008 conflict with Russia. While a number of key institutional reforms were undertaken successfully in Georgia, this 
constant paranoia has infected the political class and spread to the security services. The summer of 2011 was dominated by news of the arrest of three photographers, including the president's personal photographer, who were accused of spying for Russia. Their arrest caused popular and international condemnation. ${ }^{383}$ In addition, Georgia's tensions with Russia have had implications for the United States. Following a September 2010 bomb attack on the US embassy in Tbilisi, the head of the CID stated that a Russian military intelligence officer based in Abkhazia had organized the bombing campaign that had also targeted eleven locations in the country, an allegation that was confirmed in a leaked internal US report that identified Russian officers as the attack's organizers. ${ }^{384}$ The ability of the Georgian security and intelligence services to accomplish proper and total reform will depend completely on the political determination of the government. If the Georgian political discourse remains poisoned by allegations of Russian subversion, the line between real and imagined threats to the state, as well as the close alignment of party and state interests, will remain blurred as the services position themselves as defenders of the party in power. This would threaten to backtrack some of the progress made by the Georgian security services as they transit back towards a role befitting a political police.

The Serbian security and intelligence services have come a long way since the wars of the 1990s during which they were involved in both organized crime and war crimes. Before the Bulldozer Revolution, the security services were deeply criminalized,

${ }^{383}$ Focus Online, "Georgischer Fotograf gesteht Spionage für Russland" (18 July 2011), http://www. focus.de/panorama/vermischtes/spionage-georgischer-fotograf-gesteht-spionage-fuerrussland aid $647049 \mathrm{html}$

${ }^{384}$ E. Lake "Russian agent linked to U.S. Embassy blast" The Washington Times (21 July 2011), http://www.washingtontimes.com/news/2011/jul/21/russian-agent-linked-to-us-embassy-blast/?page=all E. Lake "Classified report: Russsia tied to blast at U.S. Embassy" The Washington Times, (27 July 2011), http://www.washingtontimes.com/news/2011/jul/21/russian-agent-linked-to-us-embassy-blast/ 
lying at the nexus of security and organized crime. This legacy has not been completely eradicated, but the situation has improved since those dark days. Broadly speaking, in political terms post-Milošević Serbia can be divided into three periods. The first, between 2000 and 2003, saw the initial difficult attempts at establishing civilian control over the security services. These attempts at the Serbian republican level were hindered by the uneasy truce between the new government and the security services. There were attempts at organizational reform with the dissolution of the SDB and the creation of BIA, as well as with the transformation of military intelligence agencies at the federal level. In addition, this period saw the beginning of cooperation between the Serbian authorities and the ICTY. However, these reform efforts were limited and it took the assassination of Đinđic for the state to seriously examine not only the need for organizational reform and further oversight, but the close links that had been formed between the security services and organized crime.

The massive operation that followed the prime minister's assassination saw the arrest of numerous criminals both within and without the security sector, although it was carried out in a way that prompted observers to raise many human rights concerns. The second period, from 2003 to 2008, was dominated by the stewardship of Koštunica as Serbian prime minister and marked by the stagnation of many reform efforts. This occurred despite the fact that Democratic Serbia's leader, Boris Tadić, held the presidency, although Tadić would become an increasingly dominant figure in Serbian politics. This alternation between pro-European governments that pursue aggressive reform efforts and more conservative governments that are not necessarily anti-European but prefer a more nationalistic development for the country reflects a division that crosses 
Serbia's political landscape. Indeed, nationalist resistance to reform resided at least in part in their perception of NATO and the United States as rivals because of Kosovo and resented the bombing of Serbia. During the Koštunica years, cooperation with the ICTY was limited and international observers worried about a potential regression. This trend was reversed following the victory of the DS-led coalition during the 2008 legislative elections. Since then, Serbian security and intelligence services have captured the three remaining ICTY fugitives, which went a long way in improving Serbia's relations with the West. In the latest EU progress report addressing Serbia's application for membership candidate status, the EU Commission noted the overall progress made in Serbia, notably in the areas of cooperation with the ICTY and in the protection of human rights. However, its ultimate conclusion remained that Serbia needed to normalize its relations with Kosovo before it can accede to candidate status. ${ }^{385}$ This recommendation highlights the main difficulty for the future of Serbia's European aspirations, as well as the limits to the role played by the international community in the reform efforts.

By imposing a resolution between Pristina and Belgrade over Kosovo's status, which amounts to demanding that Serbia recognize Kosovo's independence, the EU is creating a wedge in Serbian politics that could lead to the election of a government that would not be as favourable towards the reform process preferred by the EU. The DS-led coalition government has firm control over the executive and legislative branches of government, charting a firm pro-European course and attempting to balance a realistic approach to the Kosovo issue. The future will determine what state Serbian intelligence reform will achieve, depending greatly on the political will of the government to see the

\footnotetext{
${ }^{385}$ European Commission, "Commission Opinion on Serbia's application for membership of the European Union" Communication from the Commission to the European Parliament and the Council, 12 October 2011.
} 
reform process completed and keeping the intelligence community away from the field of domestic politics.

Although these two countries have different historical and cultural legacies, there are a number of similarities between their intelligence reform efforts. Following a twentieth century dominated by authoritarian regimes, both countries participated in vicious civil wars. In Georgia strong state institutions only developed at the expense of various war lords while Serbian institutions were profoundly criminalized. The popular uprisings that toppled these corrupt regimes gave the incoming governments strong impetus for reforms. There were challenges, both internal and external, to the reform efforts but the intelligence services in these two countries now find themselves in the transition from political polices to domestic intelligence bureaus, according to Gill's classification system. In both countries, the president and the council of ministers come from the same political movements, limiting potential political opposition and dissent. In Georgia, this situation has led to a certain degree of politicization of the security and intelligence services while the potential for regression remains present in Serbia. Overall, the success of the reform process will depend on the determination of the government in place. Overall, the reform effort has been a partial success as the security and intelligence services are now firmly within the control of the state and not of certain interest groups, has had been the case in the past.

\section{A partial confirmation of research hypothesis}

By examining the security and intelligence services at the historical, political and organizational level, the hypothesis proposed in this thesis has been partially confirmed. While institutional continuity does play an important role in fashioning or hindering the 
reform efforts, the most important element remains the presence or absence of a strong political will to enforce these changes. In both Georgia and Serbia, executive control has successfully been established and a legislative framework has been introduced to regulate most if not all of the security and intelligence services. The areas that will need to be strengthened include that of third party review and the need for governing politicians to resist the temptation of using the intelligence services to score political points. Once executive control over the security sector has been established, new governments with a strong political will can push for reform efforts and overcome issues surrounding the legacy of the security services and the consequences of institutional continuity. As part of the process of implementing executive control, officials reputedly loyal to the government are traditionally appointed to direct the security sector. This can cause a number of problems and opens the door to the politicization of the intelligence services in favour of the government of the day. In both Serbia and Georgia, the president is well entrenched and controls the levers of government. The higher degree of political plurality in Serbia creates some checks and balances within government, whereas the Georgian political landscape is completely dominated by Saakashvili's party, which stills faces a fractious opposition.

Once political control is established, a challenge for governments is to continue the reform process to assure adequate review from other branches of government and to avoid using the security and intelligence services as tools against the political opposition. The legislature must also assume its role in balancing the power of the government, even when it is formed by the majority party. If parliamentarians are not dedicated to their role in reviewing the work of the intelligence services, then there is no value added to their 
role. It can be argued that that has been the case in Georgia, where a number of organizational reforms occurred in the years following the revolution, and continue to this day, although the review of the intelligence services has been limited not by the law but by weak legislative and judicial institutions. This lack of proper review, combined with strong executive authority, has led to a certain instrumentalization of the security and intelligence services to play up the threat of the Russian spies and routinely discover new 'spy rings' that include members of the opposition, or former members of the government that had fallen out of grace. The situation was similar under the Koštunica and Tadić governments in Serbia as the political class was determined to limit external review of the security and intelligence services after successful executive control was established. While the Tadić government continues to cooperate with international organizations and pushes a strongly pro-European agenda, legislative review of the actions of the security services remains weak.

While political determination and commitment arguably remain the most important elements in intelligence reforms, the wishes of the political class remain theoretical if there is no internal appetite for reform efforts. Following the October 2000 revolution in Serbia, the structure of the security and intelligence services remained the same as it was during the Milošević years. This institutional continuity complicated the task of the democratic political elite in establishing control over the security sector as the security services remained independent power structures with ties to organized crime before eventually being reformed following 2003. Conversely, in Georgia, the security and intelligence services went through a number of structural reforms. Organizationally, the agencies of Georgia and Serbia have metamorphosed during the last decade. Reform 
efforts, lay-offs and natural attrition rates in staffing have seen the security and intelligence services play a role based less on the application of coercion and power and more on analysis and targeted missions. There have been efforts in both countries to professionalize the services through continuing training and bilateral exchange training programs where intelligence officers and analyst can benefit from the experience of NATO countries, although Serbia's cooperation with NATO has been extremely limited. To continue these initial successes, the institutional leadership of the security and intelligence services must remain committed to the reform agenda and bring a new mentality to the services.

Regarding the effectiveness of the theoretical framework for analysing intelligence reform, the hypothesis has been confirmed. While there is a consensus in the literature on the validity of this model, it is firmly embedded within the ideal of the liberal-democratic state. Unless the governments and political societies of the countries examined are committed to this ideal, then the evaluation of reform, assuming there is impetus to reform the services, would certainly fail if applied to governments that are not liberal-democratic. This is illustrated by the limits of examining intelligence reform during the communist and post-communist periods, when control and efficiency were understood in terms of the level of executive control and the success of the security services in limiting opposition to the government in place. While Gill's model allows for the categorization of the security and intelligence services in authoritarian and totalitarian systems, it does not fully capture the subtle nuances of consolidating democracies. Many of these, such as Georgia and Serbia, can fall at the halfway point between Western type 
security intelligence services and authoritarian political polices, depending on the inclinations of the government of the day.

This thesis has attempted to highlight some of the difficulties in successfully reforming the security and intelligence services of states that are undergoing transformation after decades of authoritarian governance. The hypotheses put forward have been partially confirmed: the importance of political will in supporting reform efforts; and, the negative impact of institutional continuity after the establishment of new governments. While the model used was effective in evaluating the progress of intelligence reform, it relies entirely on the premise that the ultimate objective is the establishment of the liberal-democratic state.

\section{Difficulties}

The study of security and intelligence services has revealed the difficulties of investigating or researching governmental institutions that tend to work in the shadows. The very nature of their work underlines the importance for these services to function efficiently and with accountability to the state's citizenry. The availability of official information on the security and intelligence services in and of itself can serve as a barometer to gauge the level of transparency achieved by these services.

This thesis has approached the theme of intelligence reform as a separate subject worthy of international comparison. Research in this field has been restricted to a fairly small circle of specialized academics from the United States, United Kingdom and Canada while studies on the European continent are centered on the works of the Geneva Centre for the Democratic Control of the Armed Forces. Because of this reality, the vast majority of the literature on intelligence reform is in English and reflects a potential 
cultural bias in favour of liberalism. Research institutions and non-government organizations in both Georgia and Serbia publish journals, research papers and commentaries in English, a reality that often reflects more progressive and liberal agendas. Because of the language barriers, this researcher was unable to analyze sources of information that may have been more nationalistic and conservative, which may favour different methods for reform.

Finally, as the past two points highlight, there is a need for research on intelligence reform to go beyond official institutions and news stories to find the reality on the ground. Much like the reform process itself, research on intelligence reform must be generated locally to fully grasp the nuances and subtleties proper to every culture in order for a comprehensive and exhaustive analysis to be provided.

\section{Openings for future research}

This thesis proposed to focus on intelligence reform and the relations between the political and institutional levels in consolidating democracies. By providing a comparison between two reforming societies this thesis has succeeded in examining potential trends that could be applied to other regions in which states are attempting to reform their security and intelligence services. The reform process occurring on other continents or within different cultures may draw different conclusions,

The model presented for evaluating the progress of intelligence reform is based on the premise that the ultimate goal of political transition is a liberal democratic state. It focuses heavily on institutional developments, which is understandable given the secretive nature of the services. However, this threatens to read like a cookbook approach to intelligence reform. The real progress of reform lies in the institutional mentality and 
permeates the professionalism of the members of the intelligence community. Future research into intelligence reform must strive to look beyond the institutions and into the more abstract culture that surrounds the intelligence services, the level of public trust towards these institutions and the impact these have on the reform process.

In some societies, it is considered normal for the security and intelligence services to be supportive of the government in place, a reality that does not fit with the current model for examining intelligence reform. The examination of the role of other states in intelligence reform can bring new perceptions to the model used, such as Russia's relations with Serbia and its role in intelligence relationship. In addition to different perspectives on intelligence reform, there are actors present outside state institutions. The role and participation of civil society in not only the monitoring of the activities of the intelligence community but also in the active engagement of NGOs and academics by governments, legislatures and the security and intelligence services is an area that is well worth examining. Openness to outside organizations not only improves transparency; it also challenges the security and intelligence services' analytical capacities and may help to avoid rigid institutional thinking.

Finally, this thesis, in addition to examining its main hypotheses, aimed mainly at providing an overview of intelligence reform efforts in Serbia and Georgia. Future research would benefit from researchers taking a more detailed look at internal structures and making greater use of interviews to be able to go past organizational diagrams and comprehensively examine reform efforts. While cross-regional studies are useful, comparisons of reform efforts in the Balkans and the Caucasus would be well worth the research. 


\section{Bibliography}

Abusara, A. "What is it that Europe really wants: Analysis of the Progress Reports for the West Balkans' countries for 2009 in the case of civil and democratic control", pp.66-73. Western Balkans Security Observer, n.15, October-December 2009.

Anastasijavić, D. (Vreme), "Jovica Stanisić, notre agent double à Belgrade", Courrier International, 23 April 2009, p.42

ANSA "Serbia Ex Capo 007 Milošević era uomo CIA a Belgrade”, ANSA Notizario Generale in Italiano, 2 March 2009

Antidze M. "Georgia says breaks up Russian spy network", Reuters, 5 November 2010 , Retrieved on 15 April 2011 from http://af.reuters.com/article/worldNews/idAFTRE6A41FG20101105?sp=true

AVN, "Georgia ready to accord CIA 'most favoured' treatment", $B B C$ Summary of World Broadcasts, (29 March 2000).

Axboe Nielsen, C. "Policing Yugoslavism: Surveillance, Denunciations, and Ideology during King Aleksandre's Dictatorship, 1929-1934", East European Politics and Societies, Vol.23, n.1, February 2009, pp.34-62.

B92, "Serbia has 55 security services from 40 countries: spy agency chief', $B B C$ Monitoring Services, 13 January 2010.

Babović, B. "Analysis of regulation regarding responsibility for control of the interior ministry of the republic of Serbia", Case No. IT-02-54-T, The Hague: International Criminal Tribunal for the former-Yugoslavia, 25 April 2003.

Badurina, I. "Retroscena l'ombre del tribunal dell'Aie" La Stampa, 14 March 2003, p.9.

Baev, P. K. 'Civil Wars in Georgia: Corruption Breeds Violence' in Potentials of Disorder edited by Jan Koehler \& Christoph Zürcher. Manchester: Manchester University Press, 2003, pp.127-144.

Barlovac, B. "Brammertz Report to be Favourable for Serbia" Balkan Insight, 18 November 2009, http://www.balkaninsight.com/en/article/brammertz-report-to-befavourable-for-serbia.

Bjeloš, M. "Lack of Quality Public Debate in the Process of Passing the Laws in the Security Sector", Western Balkans Security Observer, N.15, October-December 2009, pp.56-65. 
BIA, Law on the Security Information Agency, http://www.bia.gov.rs/zakonski-okvirieng.htm.

Born, H.; I. Leigh. Making Intelligence Accountable: Legal Standards and Best Practice for Oversight of Intelligence Agencies Oslo: Publishing House of the Parliament of Norway. 2005.

Born, H.; Caparini M., eds. Democratic Control of Intelligence Services: Containing Rogue Elephants. London: Ashgate, 2007.

Bruneau, T.C. \& Boraz, S.C. Reforming Intelligence: Obstacles to democratic control and effectiveness. Austin: University of Texas Press, 2007.

Bujosevic, D.; Radovanovic, I. The Fall of Milošević : The October $5^{\text {th }}$ Revolution New York: Palgrave MacMillan, 2003.

Center for the Study of Democracy. Partners in Crime: The risk of symbiosis between the Security Sector and organized crime in South East Europe, 2004.

Central Intelligence Agency, "Yugoslavia - The Fall of Rankovic" Current Intelligence Weekly Special Report, August 1966.

Civil Georgia, "Saakashvili: Recent Protest's Scenario Written in Russia", 26 May 2011, http://www.civil.ge/eng/article.php?id=23530.

Civil Georgia, “Parliament Passes 'Liberty Charter"', 31 May 2011, http://www.civil.ge/eng/article.php?id=23560.

Clark, R.M. Intelligence Analysis: A target-centric approach. Washington, D.C.: Congressional Quarterly Press, 2004.

Commission Européene pour la Démocratie et le Droit. Rapport sur le contrôle démocratique des Services de sécurité, June 2007.

Commission of the European Communities. European Union / Georgia Action Plan, (2004),

Conquest, R. Inside Stalin's Secret Police: NKVD Politics 1936-1939, Stanford: Hoover Institution Press, 1985.

Cosmon, C.; Denber, R.; J. Laber. "Conflict in Georgia: Human Rights Violations by the Government of Zvia Gamsakhurdia". Helsinki Watch News, Vol.3 Iss.16, 27

December 1991, p.3. 
Darchiashvili, D. "Georgian Defence Policy and Military Reform" in Statehood and Security, edited by Bruno Coppieters \& Rober Legvold, Cambridge: MIT Press, 2005, pp.117-151.

Economist Intelligence Unit, Country Report : Georgia, June 2011.

Edmunds, T.; German, W.N., editors, Towards Security Sector Reform in Post-Cold War Europe: A Framewsork for Assessment, Baden-Baden : Nomos Verlagsgesellschaft, 2003.

Edmunds, T. Security Sector Reform in Transforming Societies, Manchester \& New York: Manchester University Press, 2007.

Edmunds, T. "Intelligence Agencies and Democratisation: Continuity and Change in Serbia after Milosević" Europe-Asia Studies, vol.60, iss.1, January 2008, pp.25-48.

Ejdus, F. "Democratic Security Sector Governance in Serbia", Peace Research Institute Frankfurt Reports, n.94, 2010.

European Commission, "Commission Opinion on Serbia's application for membership of the European Union" Communication from the Commission to the European Parliament and the Council, 12 October 2011.

Fairbanks, C.H. "Georgia's Rose Revolution" Journal of Democracy, 15(2), April 2004, pp.110-124.

FAZ Net, "Mutmasslicher Kriegsverbrecher Hadzic gefasst" Frankfurter Allgemeine Zeitung, 20 July 2011 , www.faz.net/-02086v.

Fluri, P., editor, Security Sector Laws of Georgia, Geneva: DCAF, 2005.

Focus Online, "Georgischer Fotograf gesteht Spionage für Russland" 18 July 2011, http://www.focus.de/panorama/vermischtes/spionage-georgischer-fotograf-gestehtspionage-fuer-russland aid $647049 \mathrm{html}$.

Fritz, A. "Status report on Security Sector Governance in Georgia", Security Sector Governance in Southern Caucasus - Challenges and Visions, Vienna and Geneva: in PfP Consortium of Defence Academies and Security Studies Institutes, 2004, pp.116-164

Gazibo; J. J. La politique comparée: Fondements, enjeux, et approches théoriques. Montréal : Les Presses de l'Université de Montréal, 2004.

Geneva Center for the Democratic Control of Armed Forces. "Intelligence Services" DCAF Backgrounder, 2006. 
Georgian Intelligence Service, Law on Georgia Intelligence Service, May 2010

http://www.gis.gov.ge/docs/Dazvervis_Samsaxuris Shesaxeb.pdf

Georgian Intelligence Service, History of Georgian Intelligence Service, http://www.gis.gov.ge/html/02 en.htm

Georgian Radio, "Information and Intelligence Service promoted to Security Ministry", BBC Summary of World Broadcasts, 15 October 1993.

Georgian Radio, "Security Ministry to cooperate with CIA", BBC Summary of World Broadcasts, 22 October 1993.

Georgian Radio, "Shevardnadze news conference: Rescue Corps was 'haven for criminals", BBC Summary of World Broadcasts, 3 October 1995.

Georgian TV, "Shevardnadze sacks Security Service head; reveals further details on attack", BBC Summary of World Broadcasts, 5 September 1995.

Georgian TV, "New Georgian security minister nominated", $B B C$ Worldwide Monitoring, 14 November 2001.

Georgian TV, "Georgian security minister says Chechen field commander may be in Pankisi gorge", $B B C$ Worldwide Monitoring, 6 February 2002.

GFN-SSR. "A Beginner's Guide to Security Sector Reform" Global Facilitation Network for Security Sector Reform, Birmingham: University of Birmingham, 2007.

Gill, P. Policing Politics: Security Intelligence and the Liberal Democratic State, London: Frank Cass, 1997.

Girsiashvili, L. "Georgia needs strong and effective intelligence service", 24 Saati. 25 February 2008, http://www.gis.gov.ge/html/08 1 en.htm.

Glenny, M. "The Revolution was the Easy Part". The New York Times, 7 October 2000.

Gordadzé, T. "Police et formation de l'État en Géorgie post-Communiste" in Criminalité, police et gouvernement : trajectoires post-communistes edited by Gilles FavarelGarrigues, Paris : L'Harmattan, 2003, pp.193-232.

Hadžic, M. "Measuring the Extent of Security Sector Reform in Serbia - Framing the Problem" Western Balkans Security Observer, Serbia 2007 - Illiberal Transformation or Prolonged Transition, 2007, pp.22-28.

Hancock, M.; Varvitsiotis, M. European Security After the War in Georgia: Report to the Western European Union Assembly. Document A/2029, 4 December 2008. 
Hannah, G.; O’Brien, K.A.; Rathmell, A. "Intelligence and Security Legislation for Security Sector Reform” RAND Europe Technical Report, 2005.

Hänggi, H. "Sicherheitssektorreform (SSR) - Konzept und Kontexte", Sicherheit + Frieden, iss.3, 2005, pp.119-125.

Helsinki Committee for Human Rights in Serbia (HCHRS), Human Rights and Accountability: Serbia 2003, Belgrade, 2004.

HCHRS, Human Security in an Unfinished State - Helsinki Committee's Annual Report for 2005, Belgrade, 2006.

HCHRS, Human Rights - Hostage to the State's Regression - Helsinki Committee's Annual Report for 2006, Belgrade, 2007.

HCHRS, Self Isolation: Reality and the Goal - Helsinki Committee's Annual Report for 2007, Belgrade, 2008.

HCHRS, The Year of Violence at all Levels - Helsinki Committee's Annual Report for 2008, Belgrade, 2009.

Hopkirk, P. On Secret Service East of Constantinople. London: John Murray Publishing, 1994.

Independent International Fact-Finding Mission on the Conflict in Georgia (IIFFMCG), Report : Volume II, September 2009.

Intelligence Online "Le plan de destabilisation des Occidentaux", 8 April 1999.

Intelligence Online, "Les confidences du colonel Gavrilovic", 23 août 2001.

Intelligence Online. "Le coup d'État manqué de Serbie", 4 April 2003.

Intelligence Online, "Retour aux bonnes vielles méthodes; Belgrade" 4 October 2007.

International Crisis Group (ICG), Serbia's Transition: Reforms Under Siege Europe Report $N^{\circ} 117,21$ September 2001.

ICG, Serbia: Military Intervention Threatens Democratic Reform Europe Briefing $N^{\circ} 25$, 28 March 2002.

ICG, Fighting To Control Yugoslavia's Military Europe Briefing $N^{\circ} 26,15$ July 2002.

ICG, Serbia After Đinđić Europe Report $N^{\circ} 141,18$ March 2003. 
ICG, Serbian Reform Stalls Again Europe Report N 145, 17 July 2003.

ICG, Georgia: What Now? Europe Report 151, 3 December 2003.

ICG, Saakashvili's Adjara Success: Repeatable Elsewhere in Georgia? Europe Briefing, 18 August 2004.

ICG, Serbia: Spinning its Wheels Europe Briefing $N^{\circ} 39,23$ May 2005.

ICG, Conflict Resolution in the South Caucasus: the EU's Role Europe Report 173, 20 March 2006.

ICG, Georgia: Sliding Towards Authoritarianism? Europe Report 189, 19 December 2007.

ICG, Georgia and Russia: Clashing Over Abkhazia Europe Report 193, 5 June 2008.

ICG, Georgia vs. Russia: The Fallout Europe Report 195, 22 August 2008.

ICG, Georgia: the Risks of Winter, Update Briefing, 26 November 2008.

Interfax "Georgia: Security Minister Says Former Security Chiefs Were Spies", $B B C$ Summary of World Broadcasts, 19 July 1996.

Interfax, "Security chief announces "global reform" in ministry", BBC Summary of World Broadcasts, (24 July 1997).

Johnson, L. K. "Brick and Mortar for a Theory of Intelligence", Comparative Strategy, 22, 2003, pp.1-28.

Knight, A. Beria: Stalin's First Lieutenant, Princeton, NJ: Princeton University Press, 1993.

Knight, A.W. The KGB : Police and Politics in the Soviet Union, Boston: Unwin Hyman, 1990.

Karumidze, Z.; Wertsch, J. Enough! The Rose Revolution in Georgia New York: Nova Science Publishers, 2005.

Lake, E. "Russian agent linked to U.S. Embassy blast" The Washington Times, 21 July 2011, http://www.washingtontimes.com/news/2011/jul/21/russian-agent-linked-tous-embassy-blast $/$ page $=$ all

Lake, E. "Classified report: Russsia tied to blast at U.S. Embassy" The Washington Times, 27 July 2011, http://www.washingtontimes.com/news/2011/jul/21/russianagent-linked-to-us-embassy-blast. 
Lampe, J.R. Yugoslavia as History, $2^{\text {nd }}$ Edition, Cambridge: Cambridge University Press, 2000.

Lang, D.M. A Modern History of Georgia, London: Weidenfield and Nicolson, 1962.

La Repubblica, "Arrestato Ratko Mladic "Il boia" di Srebrenica", 26 May 2011, http://www.repubblica.it/esteri/2011/05/26/news/mladic_arresto-16775314/.

Larsson, R. L. "Georgia's Search for Security: An Analysis of Georgia's National Security Structures and International Cooperation" Occasional Paper \# 1, Georgian Foundation for Strategic and International Studies, 2003.

Le Point "Portrait; Jovica Stanišić le prétorien de Miloševié", 3 May 1997.

Lundum, J.; Said Pullicino, J. and A. Suirante, "Les Services de Sécurité Intérieur en Europe" Commission Européene pour la Démocratie par le Droit, 7 March 1998.

Martens, M. "Ein gutter Tag für Serbien", Frankfurter Allgemeine Zeitung, 26 May 2011, http://www.faz.net/artikel/C30089/kommentar-ein-guter-tag-fuer-serbien-30376391.html.

Martin, A. "The lessons of Eastern Europe for modern intelligence reform" Conflict, Security \& Development, vol.7, iss.4, December 2007, pp.551-577.

McGiffert Ekedahl, C.; Goodman, M.A. The Wars of Eduard Shevardnadze, University Park: Pennsylvania State University Press, 1997.

Mikadze, A. "Midnight Terrorism", Moscow News, 19 February 1998.

Milosavljević, B. "Three General Problems Faced by Security Studies in Serbia and Other Countries in Transition" Western Balkans Security Observer, iss.6, July September 2007, pp.50-54.

Miller, G. "Serbian spy's trial lifts cloak on his CIA alliance" The Los Angeles Times, 1 March 2009.

Milosavljević, B. "A Review of the Proposed Law on the Security Services in the Republic of Serbia" Western Balkans Security Observer, iss.7-8, December 2007, pp.102-107.

Milivojevic, M. "The Political Role of the Yugoslav People's Army in Contemporary Yugoslavia" in Yugoslavia's security dilemmas : armed forces, national defence, and foreign policy, edited by M. Milivojevic, J.B. Allcock, and P. Maurer. New York : Berg, 1988. pp.15-59. 
Milivojević, M. "The Role of the Yugoslav Intelligence and Security Community" Yugoslavia in transition : choices and constraints, edited by J.B. Allcock, J.J. Horton and M. Milivojevic, New York : Berg, 1992, pp.199-237.

Ministry of Internal Affairs (Georgia) Statement of the Ministry of Internal Affairs, 9 July 2011 , http://www.police.ge/index.php?m=8\&newsid $=2642$.

Ministry of Internal Affairs (Georgia) Ministry of Internal Affairs of Georgia detained several persons covertly working for GRU, 5 November 2010 , http://www.police.ge/index.php?m=8\&newsid=1669.

NATO, AAP-6 (NATO Glossary of Terms and Definitions), 2009.

NTV, "Georgian and Russian security services meet to discuss tactics", BBC Summary of World Broadcasts, 5 March 2002.

O'Reilly, C. "Serbia extradites Karadzic to Hague" Jane's Intelligence Review, July 2008.

Parliament of Georgia, National Security Concept of Georgia, 2005, http://www.parliament.ge/files/292 880927746 concept en.pdf.

Pataroa. T., editor, Democratic Control over the Georgian Armed Forces since the August 2008 War, Geneva: Centre for the Democratic Control of the Armed Forces, 2010.

Pavloviç, V. "La mémoire et l'identité nationale: la mémoire de la grande guerre en Serbie" Guerres mondiales et conflits contemporain, 2007/4, n.228, pp.51-60.

Petrović, P. "Incomplete step towards reform of the security intelligence system in Serbia - Critical retrospective view at the draft law on the basic structure of the Republic of Serbia security agencies" Western Balkans Security Observer, December 2007, pp.108-114.

Petrović, P. "Commentary on the Law on Military Security Agency and Military Intelligence Agency", Western Balkans Security Observer, n.15, OctoberDecember 2009, pp.11-21.

Popović, D, "Commentaries on the Law on Classified Information", Western Balkans Security Observer, n.15, October-December 2009, pp.3-10.

Pörzen, G. "Nach dem Mord an Zoran Đindić", Südosteuropa Mitteilungen, 02/2003, pp.29-33.

Prime-News, "Intelligence chief optimistic about his department's activities", $B B C$ Summary of World Broadcasts, 14 October 1997. 
Prime-News, "Georgian security chief saying unpaid staff leaving ministry", $B B C$ Worldwide Monitoring, 18 May 2000.

Radoman, J. "The Concept of Security Sector Reform" Western Balkans Security Observer, n.11, October-December 2008, pp.4-10.

Rakić-Vodinelić, V. "An Unsuccessful Attempt of Lustration in Serbia", in Lustration and consolidation of democracy and the rule of law in Central and Eastern Europe, edited by V. Dvořáková, and A. Milardović, Zagreb: Political Science Research Centre, 2007, pp.169-182.

Ramet, S.; Pavlakovic, V. Serbia Since 1989. Seattle: University of Washington Press, 2005.

Rusinow, D. The Yugoslav Experiment 1948-1974, London: C. Hurst and Company, 1977.

Rustavi-2, "Georgia admits foreign fighters are still in the Pankisi Gorge", BBC Summary of World Broadcasts, 21 October 2002.

Spaić, T. "Serbia to file application for candidate status middle of December" Blic, 19 November 2009.

Torkildsen, M. "Amended Expert Report of Morten Torkildsen", Case No.IT-02-54-T, International Criminal Tribunal for the former-Yugoslavia, 7 June 2002.

Venice Commission, Rapport sur le contrôle démocratique des Services de sécurité (June 2007).

Waller, J. M. Secret Empire: The KGB in Russia Today, Boulder: Westview Press, 1994.

Walt, C. "Regime Vulnerability and Popular Mobilization in Georgia's Rose Revolution" CDDRL Working Paper n.67, September 2006.

Watts, L.L. "Intelligence Reform in Europe's Emerging Democracies", Studies in Intelligence, Vol.41, Iss.1, pp.11-25, 2004.

Weber, M. Politik als Beruf, 1919 [electronic version] retrieved on 13 January 2011 from $<$ http://de.wikisource.org/wiki/Politik_als_Beruf $>$.

Weber, M. "S.7 Legitime Ordnung" in Wirtschaft und Gesseschaft, 1922 [electronic version] retrieved on 13 January 2011 from

$<\mathrm{http} / /$ www.unilibrary.com/ebooks/Weber, $\% 20 \mathrm{Max} \% 20$ -

$\% 20$ Wirtschaft\%20und\%20Gesellschaft.pdf $>$. 
Wheatley, J. Georgia from National Awakening to Rose Revolution: Delayed Transition in the Former Soviet Union, Aldershot: Ashgate, 2005.

Wills, A. Understanding Intelligence Oversight, Geneva: DCAF, 2010.

Wilson, P. "The contribution of intelligence services to security sector reform" in Conflict, Security \& Development, Vol.5, Iss.1, April 2005. pp.87-107,

Wittlin, T. Commissar: the Life and Death of Lavrentiy Pavlovich Beria, New York : Macmillan, 1972.

Zaccaria, Giuseppe. "In Serbia la battaglia per la democratia e'ancora lontana dalla conclusione", La Stampa, 14 March 2003.

Zorkin, V.D. "Comments on Democratic Oversight of Special Services in Eastern Europe", Venice Commission, May 2007.

Zürcher, C.; Baev, P.; J. Koehler. "Civil Wars in the Caucasus" in Understanding Civil War, Vol. 2, edited by P. Collier \& N. Sambonism, Washington: The World Bank, 2005, pp.259-298. 